Studia Philosophiae Christianae

UKSW

$51(2015) 4$

\title{
INTEGRALNOŚĆ POZNANIA LUDZKIEGO W UJECIU BLAŻEJA PASCALA. Z DZIEJÓW FILOZOFII ZDROWEGO ROZSĄDKU
}

Streszczenie. Artykuł omawia koncepcję poznania w ujęciu Błażeja Pascala na tle dyskusji epistemologicznych XVII i XVIII wieku. Wskazuje na integralność ludzkiej wiedzy postulowanej przez Pascala. Winna ona zespalać z jednej strony rozum, pojęty w sensie operacji dyskursywnej, z intuicją i instynktem, a z drugiej - poznanie naturalne $\mathrm{z}$ wiarą. Pascal wychodzi poza zestaw prawd dostępnych w poznaniu ugruntowanym na dyskursie (raison). Szczególną rolę wyznaczał intuicji określanej w kategoriach sentir czy nawet instinct, operując takimi kategoriami jak esprit de finesse, utożsamiany z sens droit czy esprit de justesse, istotnymi w odniesieniu do poznania principes. Równocześnie tak pojęte wyposażenie ludzkiego umysłu (lumière naturelle) odpowiada aspektywnie wiedzy ugruntowanej na cœur, przeciwstawianej interpretowanemu racjonalistycznie raison, gdy na gruncie religii lumière naturelle jest komplementarne wobec inspiration czy révélation.

Podejście to, opozycyjne wobec przejawów naturalistycznie pojętego racjonalizmu, wydaje się wpisywać w długi ciąg filozofii zdrowego rozsądku liczącej się z realiami ludzkiej natury. Sięga ona myśli Arystotelesa, mimo nowożytnej kontestacji jego nauki. Punktem odniesienia rozważań Pascala nade wszystko jest jednak epistemologia Kartezjusza podkreślającego znaczenie apriorycznych elementów poznania, traktowanych jako naturalne wyposażenie ludzkiego umysłu, do których odwołuje się intuicja czy instynkt. Konsekwencją integralności poznania jest akceptacja maksymalistycznie pojętej filozofii, nawet jeśli w nowożytności zmienił się paradygmat - z metafizycznego na epistemologiczny. Traktowanie ówczesnych ograniczeń w zakresie wykładu metafizyki jako przejawu minimalizmu, a nawet swoistego agnostycyzmu, nie wydaje się jednak uprawnione dlatego, że ze względu na zmianę nowożytnego

Stanisław Janeczek janeczek@kul.lublin.pl
Katolicki Uniwersytet Lubelski, Wydział Filozofii

al. Racławickie 14, 20-950, Lublin 
paradygmatu to epistemologia była głównym terenem, na którym rozgrywały się podstawowe spory filozoficzne. Owocowały one określonymi rozstrzygnięciami światopoglądowymi, istotnymi w perspektywie ówczesnej dominacji kultury religijnej. Być może nawet, że to właśnie religijne milieu wymuszało podjęcie wątków metafizycznych, które stanowiłyby fundament światopoglądu religijnego. W tym kontekście wymóg ten aktualizowało ówczesne szkolnictwo, preferując u schyłku wieku oświecenia szkocką filozofię zdrowego rozsądku, broniącą integralności ludzkiej wiedzy wobec przejawów filozoficznego minimalizmu, a nawet swoistego sceptycyzmu, groźnego dla ładu kulturowego.

Słowa kluczowe: Błażej Pascal, René Descartes, Thomas Reid, historia epistemologii, historia filozofii nowożytnej

1. Kontekst interpretacyjny. 2. Epistemologia Pascala. 3. Epilog oświeceniowy. 4. Podsumowanie.

„Effrayant génie”, „druzgocący geniusz” - jak w sposób przejmujący wypowiedział się o Błażeju Pascalu w Le Génie du christianisme inny genialny Francuz, René Chateaubriand, obdarzony podobną głębią przeżyć naznaczonych równie skomplikowanym doświadczeniem życiowym ${ }^{1}$ - budzi wciąż zainteresowanie historyków nauki, filozofów i teologów. Wielość płaszczyzn rozważań, brak systematyczności, a nawet całościowości wywodu i towarzyszący mu patos, tłumaczy wielość interpretacji dotyczących uwikłanej wielorako epistemologii, służącej tyleż przyrodoznawstwu, co religii, a nadto uwikłanej w różny od współczesnego kontekst argumentacyjny, naznaczony specyfiką barokowej kultury, w której centralną rolę odgrywała retoryka ${ }^{2}$. Obok

1 R. Chateaubriand, Le Génie du christianisme, t. 1-2, Paris 1866; https://archive.org/stream/legnieduchrist00chatuoft/legnieduchrist00chatuoft_djvu.txt [dostęp 7.10.2015]; Przekład tego fragmentu znajduje się na obwolucie polskiego wydania Pensées de M. Pascal sur la religion et surquelques autres sujets, Paris 1670; cyt. jako Pensées, wyd. J. Chevalier, w: B. Pascal, Euvres complètes, Paris 1954; toż jako: Myśli, tłum. z franc. T. Żeleński-Boy, Warszawa 1972; wzmiankowanego tekstu nie ma w wyborze Geniusz chrześcijaństwa, tłum. z franc. A. Loba, Poznań 2003.

2 Zob. E.R. Koch, Pascal and Rhetoric. Figural and Persuasive Language in the Scientific Treatises, the „Provinciales”, and the „Pensees”, Charlottesville 1997; Th. Parker, Volition, Rhetoric, and Emotion in the Work of Pascal, New York 2008; J.F. Boitano, Polemics of Libertine Conversion in Pascal's „,Pensées”, Tübingen 2002. 
dominujących prób ujmowania dokonań Pascala w kategoriach racjonalizmu i intuicjonizmu, wydaje się, że można również szukać analogii z wpływowym i trwałym nurtem filozofii zdrowego rozsądku, w perspektywie którego klarowniej uwidacznia się tytułowa integralność epistemologii myśliciela z Port-Royal.

\section{KONTEKST INTERPRETACYJNY}

W historii kultury intelektualnej zwykło się dokonanie Pascala postrzegać nade wszystko jako przejaw fideizmu³. Autor Pensées, które są przecież zalążkami apologii wiary formułowanej wobec pojawiających się prób sekularyzacji ludzkiego myślenia w nowożytnej Europie, był także znakomitym matematykiem i fizykiem, trudno więc

3 Bez jakichkolwiek zastrzeżeń myśl Pascal jako przejaw fideizmu traktuje Powszechna encyklopedia filozofii: „Ścisły fideizm głosił W. Ockham, wg którego jedynie dzięki wierze możemy osiągnąć pewność istnienia Boga, nieśmiertelności duszy i prawa moralnego. Podobne poglądy głosili: Mikołaj z Autrecourt, B. Pascal i P.D. Huet”. Z. Chlewiński, Fideizm, w: Powszechna encyklopedia filozofii, t. 3, red. A. Maryniarczyk i in., Lublin 2002, 427. Równie zdecydowanie wypowiada się w analogicznym haśle The Stanford Encyclopedia of Philosophy, stwierdzając: „Today the term »fideism « is perhaps most commonly associated with four philosophers: Pascal, Kierkegaard, James, and Wittgenstein". Jednak zaznacza, że nie jest to jednoznaczne $\mathrm{z}$ antagonistycznym nastawieniem do rozumu, ale raczej w sensie wskazania jego granic i innych sposobów poznania, a nawet słynny ,zakład” traktuje jako przejaw racjonalnego uprawomocnienia wiary, ale w sensie antycypującym rozwiązanie Kanta, czyli na poziomie rozstrzygnięć praktycznych (egzystencjalnych): „In any event, it is worth noting that Pascal and his intellectual heirs, though frequently characterized as fideists, are not antagonistic to reason tout court. In the first place, as Pascal sees it, it is reasonable to acknowledge limits to reason. »Reason's last step is the recognition that there are an infinite number of things which are beyond it« (209). It is in this spirit that he suggests, somewhat more elliptically, that $»[t]$ here is nothing which is so much in conformity with reason as the rejection of reason« (209). Thus, Pascal invokes reason to justify what might otherwise appear to be its antithesis. Moreover, the aim of the »Wager« argument is precisely to secure the rational respectability of faith in the face of an apparent antinomy. In this respect, Pascal's approach anticipates Kant's contention that God's existence is a question for practical - as opposed to theoretical - reason". R. Amesbury, Fideism, w: The Stanford Encyclopedia of Philosophy (Winter 2012 Edition), red. E.N. Zalta, http://plato.stanford.edu/entries/fideism/ [dostęp 3.09.2015]. 
byłoby wymagać od niego, by nie doceniał możliwości ludzkiego umysłu w dobie obiecujących odkryć dokonywanych na gruncie sciences, stąd reflektuje w L'Esprit de la géométrie ich status metodologiczny ${ }^{4}$. Wskazuje się, że jeśli Pascal nawet przeciwstawiał wiarę rozumowi, to przecież nie po to, by rozum deprecjonować; wprost przeciwnie, w dobie postępującego racjonalizmu, traktowanego jako przejaw postępu ludzkiego ducha (l'histoire de l'esprit humain) ${ }^{5}$, ukazywał jego możliwości i znaczenie tyleż w odniesieniu do statusu człowieczeństwa, co i do uprawomocnienia wiary chrześcijańskiej. Nawet pobieżna lektura Myśli wskazuje, że według Pascala intelektualne możliwości człowieka są bowiem fundamentem jego wielkości, bo to „myśl stanowi wielkość człowieka”, i godności, skoro „cała godność człowieka jest w myśli”, a jeśli tak, to „silmy się tedy dobrze myśleć: oto zasada moralna" Choć jak wyszukany sceptyk, Pascal wskazywał na ograniczenia ludzkiego rozumu, a przede wszystkim na złe jego wykorzystanie, to przecież równocześnie przestrzegał przed dwoma równie groźnymi skrajnościami, by „wykluczyć rozum, przyjmować tylko rozum”9. Co ciekawsze, Pascal nie tylko dostrzegał zagrożenie w wykorzystaniu rozumu jako narzędzia „pognębienia religii chrześcijańskiej”10, ale także - jako programowy racjonalista - w zaszczytnej służbie rozumu

4 Współczesne wydanie tego już opublikowanego pośmiertnie tekstu ukazało się początkowo w formie dwu samoistnych elementów, czyli De l'art de persuader (w: P.-N. Desmolets, Continuation des Mémoires de littérature et d'histoire, t. 5/2, Paris 1728, 271-296) oraz De l'esprit de la géométrie (fragment w: P.-N. Desmolets, Continuation des Mémoires, dz. cyt., 302-331; pełne wydanie wraz z pełniejszym wydaniem Pensées, wyd. A. de Condorcet, Paris 1776). Całość cyt. jako L'Esprit de la géométrie et De l'art de persuader, w: B. Pascal, Euvres complètes, dz. cyt., 575-604; tłum. z franc. M. Tazbira jako: Rozważania ogólne nad geometrią. O geometrycznym sposobie myślenia i o sztuce przekonywania, w: B. Pascal, Rozprawy i listy, Warszawa 1962, 113-156.

5 P. Chaunu, Cywilizacja wieku Oświecenia, tłum. z franc. E. Bąkowska, Warszawa 1993, 216-219.

6 B. Pascal, Myśli, dz. cyt., 117; Tenże, Pensées, dz. cyt., 1156.

7 B. Pascal, Myśli, dz. cyt., 117; Tenże, Pensées, dz. cyt., 1156.

8 B. Pascal, Myśli, dz. cyt., 118; Tenże, Pensées, dz. cyt., 1157.

9 B. Pascal, Myśli, dz. cyt., 27; Tenże, Pensées, dz. cyt., 1089.

10 B. Pascal, Myśli, dz. cyt., 27; Tenże, Pensées, dz. cyt., 1089. 
wobec wiary religijnej widział niezbędny warunek jej autentyczności: „Jeśli się wszystko podda rozumowi, nasza religia nie będzie miała nic tajemniczego ani nadprzyrodzonego; jeśli się pogwałci zasady rozumu, będzie niedorzeczna i śmieszna"ll.

To uniwersalistyczne przesłanie doskonale wpisuje się w opinię współczesnych wielkich papieży, począwszy od encykliki Jana Pawła II Fides et ratio ${ }^{12}$, ale i licznych wypowiedzi Benedykta XVI, który sprzeciwiał się nowożytnej i współczesnej wizji autonomicznego rozumu $^{13}$, żądając „poszerzania granic racjonalności”14 , bowiem „próba wyjścia $\mathrm{z}$ bagna niepewności wyłącznie za pomocą autonomicznego rozumu, który nie chce mieć do czynienia z wiarą, ostatecznie nie

11 B. Pascal, Myśli, dz. cyt., 27; Tenże, Pensées, dz. cyt., 1089.

12 Pisząc z wyraźną predylekcją o ,wielkiej encyklice o wierze i filozofii”, za jaką uznawał Fides et ratio, Joseph Ratzinger stwierdzał: „Papież, wychodząc od wiary, wymaga od rozumu odwagi w uznaniu rzeczywistości podstawowych. Jeśli wiara nie żyje w świetle rozumu, popada w czysty tradycjonalizm, a tym samym przypieczętowuje swoją radykalną arbitralność. Wiara potrzebuje odwagi rozumu. Wiara nie sprzeciwia się rozumowi, lecz pobudza go, aby własnymi siłami zmierzył się z wielkimi celami, do jakich został stworzony. Sapere aude! Wymagaj od siebie wielkich rzeczy! Do tego bowiem jesteś przeznaczony. (...) zadaniem wiary jest pobudzanie rozumu do nowej odwagi w poznawaniu prawdy. Wiara bez rozumu ginie. Rozum bez wiary narażony jest na wyjałowienie. Tu chodzi o człowieka”. Benedykt XVI, Mój umiłowany Poprzednik, tłum. z wł. R. Łobko, Częstochowa 2007, 55-56. Zob. Jan Paweł II, Fides et ratio. Tekst i komentarze, red. T. Styczeń, W. Chudy, Lublin 2003; Rozum otwarty na wiarę. ,„ Fides et ratio« - w rocznicę ogłoszenia”. II Międzynarodowe Sympozjum Metafizyczne (KUL, 9-10.XII.1999), red. A. Maryniarczyk, A. Gudaniec, Lublin 2000.

13 O nowożytnej i współczesnej filozofii dławionej przez scjentyzm pisał Ratzinger: „Ta filozofia nie wyraża pełnego rozumu człowieka, ale tylko jego część, i w związku z tym okaleczeniem rozumu nie można jej uważać za całkowicie rozumną" (J. Ratzinger, Europa Benedykta w kryzysie kultur, tłum. z niem. W. Dzierża, Częstochowa 2005, 61).

14 Benedykt XVI, Wróćmy do filozofii, by lepiej zrozumieć współczesność. Do uczestników VI Europejskiego Sympozjum Nauczycieli Akademickich (7 VI 2008), L'Osservatore Romano 29(2008), wydanie polskie, 10(2008)7-8, 21. Zob. M. Rembierz, Rozum otwarty i jego wrogowie? Logos i rozum w argumentacji Josepha Ratzingera (Benedykta XVI), w: W kręu teologii Josepha Ratzingera-Benedykta XVI, red. K. Wolsza, Opole 2008, 203-230. 
może się udać. Rozum ludzki nie jest bowiem wcale autonomiczny"15. „Zbawienie rozumu jako rozumu”, tak by „nie pogwałcić jego praw”, może dokonać się paradoksalnie dzięki jego otwarciu na wiarę, bo tylko wiara może ,przywrócić rozum samemu sobie"16. Potrzeba więc dramatycznie ,nowego dialogu” między wiarą i filozofią, uwzględniającego współczesny kontekst kulturowy, „bowiem obie te dziedziny wzajemnie się potrzebują”; „rozum nie może być zdrowy bez udziału wiary, lecz wiara bez rozumu nie będzie $1 \mathrm{udzka}$ [podkr. - SJ]"'17.

Szukając specyfiki epistemologicznej dokonania Pascala nierzadko przeciwstawia się jego fideizm równie skrajnemu racjonalizmowi Kartezjusza. Choć Zbigniew Drozdowicz, znawca twórczości obydwu myślicieli, zalicza myśliciela z Port-Royal do kręgu „,antagonistów” Kartezjusza, bo przecież wprost formułował szereg „krytycznych uwag na temat Kartezjusza - w rodzaju »Kartezjusz bezużyteczny i niepewny «"18, to przecież równocześnie dostrzega w propozycji Pascala ,gruntownie uzasadnioną i niebanalną kontrpropozycję widzenia Boga, świata i człowieka”. Choć jest ona „z ducha i treści antykartezjańska, ale nie racjonalistyczna czy antyintelektualistyczna", nawet gdy jest to ,inny rodzaj intelektualizmu niż kartezjański”. Dodaje, że nawet „więcej jest w nim krytycznego wątpienia niż u Kartezjusza, a w konsekwencji mniej uproszczeń", tym bardziej, że w porównaniu z kartezjanizmem myśl Pascala jest bardziej wartościowym duchowym i intelektualnym przewodnikiem na drogach ludzkiej egzystencji; cennym równocześnie w zakresie pogłębienia religijności jako takiej, różnej od bezkrytycznie optymistycznej poznawczo religijności ludowej, którą

15 J. Ratzinger, Wiara - prawda-tolerancja. Chrześcijaństwo a religie świata, tłum. z niem. R. Zajączkowski, Kielce 2004, 109.

16 Równocześnie Ratzinger krytykuje współczesną teologię, bowiem „,brakuje jej odwagi całkowitego rozbudzenia rozumu”. J. Ratzinger, Wykłady bawarskie z lat 1963-2004, tłum. z niem. A. Czarnocki, Warszawa 2009, 93. Zob. J. Szymik, „Logos” $i$,ratio”. J. Ratzingera/Benedykta XVI opowieść o Bogu, który obdarza łaska rozumu i łaska wiary, Teologia w Polsce 6(2012)1, 5-19.

17 Tamże, 110.

18 B. Pascal, Myśli, dz. cyt., 92; Tenże, Pensées, dz. cyt., 1137. 
jednak - realistycznie, jak Kartezjusz - akceptował, skoro jest „prostym ludziom potrzebna" 19 .

Co ciekawe, tę równowagę między rozumem a wiarą dostrzegają w myśli Pascala także teologowie i historycy nauki. W pierwszym przypadku Tadeusz Dzidek sądzi, że „Pascalowski zakład, ów probabilistyczny wywód, jest jednak dopiero przygotowaniem człowieka do wiary" ${ }^{20}$, a dopiero angażująca całe ludzkie przeżywanie i wymagająca nawrócenia wiara „otwiera drogę do doświadczenia Boga żywego Abrahama, Izaaka, Jakuba, a nie Boga filozofów i uczonych, który jest jedynie rozumowym postulatem sensu”21. Interpretuje jednak „rozum (raison, esprit)" jako „właściwość wybitnie dyskursywną, opartą na zasadach i dowodzeniu"22, a równocześnie dostrzega znaczenie ,jeszcze jednej, wyróżnionej przez Pascala władzy poznawczej »serce« (cceur, instinct, sentiment), zdolności intuicyjnej, która pozwala dostrzec ostateczne założenia jednym spojrzeniem”23. „Przyjęcie argumentu Pascala nie zamienia prawdopodobieństwa w pewność, lecz wskazuje postawę, którą można uznać za bardzo racjonalną pragmatycznie. Wybór, rozstrzygnięcie zakładu wynika nie tyle z teoretycznej potrzeby rozumu, co z ludzkiej potrzeby, a nawet konieczności, podjęcia działania praktycznego" ${ }^{24}$, zwłaszcza że człowiek jest postawiony między perspektywą „absurdu” albo „odkrycia Sensu”25.

W pogłębionym filozoficznie wywodzie teologicznym Hans-Martin Rieger także akcentuje w myśli Pascala prymat lumen fidei nad lumen naturale. Równocześnie jednak wskazuje na znaczenie szeroko

19 Z. Drozdowicz, O racjonalności w filozofii nowożytnej. Wykłady, Poznań 2008, 23-25. Por. Tamże, 9-26; Tenże, Blaise Pascal versus Descartes, w: Tradycja a współczesność, red. R. Kozłowski, Poznań 1981, 43-52; S. Janeczek, Z dziejów genezy nowożytnej filozofii religii. Kartezjusz, w: Abiit, non obiit. Księga poświęcona pamięci Księdza Profesora Antoniego Kościa SVD, red. A. Dębiński i in. Lublin 2013, $575-587$.

20 T. Dzidek, Granice rozumu w teologicznym poznaniu Boga, Kraków 2001, 42.

21 Tamże, 42-43.

22 Tamże, 40.

23 Tamże, 41.

24 Tamże, 42.

25 Tamże, 37. 
rozumianych ludzkich kompetencji racjonalnych, także w zakresie światopoglądowym, np. w uzasadnianiu istnienia Boga, chociażby urzeczywistnianym w perspektywie praktycznego wymiaru ludzkiego życia. Przywołując znane już św. Tomaszowi z Akwinu rozróżnienia na intuicyjnie traktowany intellectus i dyskursywnie pojęte ratio, Rieger przestrzega także przed upraszczającym zestawianiem dokonania $\mathrm{Pa}$ scala z epistemologią Kanta, gdyż raison obejmuje zarówno Vernunft, jak i Verstand, intelekt natomiast cour lub esprit de finesse. Przeciwstawia się stąd przypisywaniu dokonaniu myśliciela z Port-Royal zarówno kwalifikacji Fideismus, jak równie radykalnego, irracjonalistycznego Dezisionismus, bliskiego np. tradycji kantowskiej ${ }^{26}$.

W odniesieniu do rozważań z zakresu historii nauki zwracają uwagę wyraziste sformułowania zawarte w dokonanej przez Michała Hellera prezentacji monografii Williama R. Shea Designing Experiments and Games of Chance - The Unconventional Science of Blaise Pascal ${ }^{27}$. Polemizuje on z rozpowszechnionym traktowaniem myśli Pascala jako religijnego sentymentalizmu, polegającego na oddzielaniu sfery religii, której twierdzenia zaliczał do ,prawd serca”, od sfery nauki, która ma się kierować wyłącznie racjami rozumowymi. „Takie postawienie sprawy wynika z pobieżnej lektury Pascala. Istotnie, mówił on o »czuciu serca«, ale w zupełnie innym kontekście. Należy, jego zdaniem, odróżnić »zwykłe używanie rozumu«, które polega na dedukowaniu wniosków z przesłanek, i wiedzę bezpośrednią (niekiedy nazywał ją " »pierwszymi zasadami«), która dotyczy liczby, ruchu, przestrzeni i czasu. Wiedza ta, "pochodząca z serca«, jest »tak samo solidna jak wiedza pochodząca z rozumu«". Na przykład »serce czuje«, że są trzy przestrzenne wymiary i że ciąg liczb jest nieskończony. Tego rodzaju wiedza wcale nie jest gorsza od wiedzy rozumowej. Pascal woła: »Jakby rozum był tylko jedyną drogą do poznania! Na Boga, przeciwnie, obyśmy nigdy jej nie potrzebowali i wiedzieli wszystko poprzez instynkt i czucie!« (s. 215).

26 H.-M. Rieger, Menschlich denken - Glauben begründen. Blaise Pascal und religionsphilosophische Begründungsmodelle der Moderne, Berlin 2011, 329-335. Szerzej zob. Tamże, 145-218.

27 Cantonn, MA, 2003. 
A więc »serce« $\mathrm{i}$ »uczucie« znaczą u Pascala zupełnie co innego niż w naszym potocznym języku" ${ }^{28}$.

Sformułowania te eksponują znaczenie wiedzy ugruntowanej na innym niż stricte racjonalny fundament. Dotyczy to już odrębności wobec generalizująco wiązanego z nowożytnym racjonalizmem dyskursywnego stylu uprawiania filozofii, czy szerzej pojętej nauki, związanego z ideałem more geometrico ${ }^{29}$, charakterystycznym np. dla Barucha Spinozy, nie tylko w aspekcie metodyki wykładu, dzięki czemu miał on zyskać na przejrzystości i systematyczności (more geometrico dispositum), ale nade wszystko traktując go jako metodę dowodzenia (more geometrico demonstratum) ${ }^{30}$. Eksponowanie znaczenia tak pojętej tradycji racjonalistycznej związane jest z jej trwałością, także w wieku XVIII, m.in.za sprawą tak wpływowej postaci w oświeceniowej kulturze filozoficznej jaką był Christian Wolff ${ }^{31}$. Na niebezpieczeństwo

28 M. Heller, Pascal - uczony niekonwencjonalny, Zagadnienia Filozoficzne w Nauce 36(2005), 156-159.

${ }^{29}$ Zdaniem Ch. Wolffa, który referował już blisko wiek trwające podówczas dyskusje na temat roli metody matematycznej, jej nazwa wywodzi się z faktu wykorzystania tej metody przez matematyków, nie zaś z tego, że była to metoda właściwa matematyce. Mathematisches Lexicon, Leipzig 1716, 890.

${ }^{30}$ B. Spinoza odwołuje się wprost do metodologii kartezjańskiej (Renati Des Cartes Principiorum philosophiae pars I et II more geometrico domonstratae, Amstolodami 1663), stwierdzając kategorycznie: „Mathematicorum in scientiis investigandis, ac tradendis methodum, qua nempe ex definiotnibus, postulatis atque axiomatibus conclusiones demonstrantur, optimam esse tutissimamque veristatis indagandae atque docendae viam, omnium qui supra vulgum sapere volunt, unanimis est sententia". Renati Des Cartes Principiorum philosophiae pars I et II more geometrico domonstratae, Amstolodami 1663; toż w: Tenże, Opera, wyd. C. Gebhardt, t. 1, Heildelberg 1925, 127. Zob. W. Risse, Die Logik der Neuzeit, t. 2: 1640-1780, Stuttgart 1970, 92-96. Por. W. Schmidt, Intuition und Deduktion. Untersuchungen zur Grundlegung der Philosophie bei Spinoza, w: K. Peters, W. Schmidt, H.H. Holz, Erkenntnisgewißheit und Deduktion. Zum Aufbau der philosophischen Systeme bei Descartes, Spinoza, Leibniz, Darmstadt 1975, 57-128.

${ }^{31}$ Rozumienie matematycznej metody dowodzenia, uznanej za metodę filozofii, sformułował Wolff najpełniej w Kurtze Unterricht von der mathematischen Methode, którą rozpoczyna Anfangsgründe aller mathematischen Wissenschaften (Halle 1710; polski przekład z niem. w: R. Kuliniak, T. Małysz, XVII i XVIII-wieczne popularne podręczniki studiowania matematyki. Ze szczególnym uwzględnieniem Christiana 
tak jednostronnej interpretacji racjonalizmu nowożytnego zwracał już uwagę Władysław Tatarkiewicz, wskazując na ,intuicyjny” charakter racjonalizmu Kartezjusza, różny od „dyskursywnego racjonalizmu” Leibniza $^{32}$.

Intuicjonizm Kartezjusza miał jednak bardzo złożone oblicze, można bowiem w nim widzieć także przejaw tradycji zwieńczonej dokonaniami szkockiej filozofii common sense, w której to podkreślano znaczenie dostępnych intuicyjnie czy instynktownie pierwszych zasad poszczególnych nauk ${ }^{33}$. Podejście to, istotne w kręgu nasilającego się sekularyzmu, wspartego gwałtowną krytyką metafizyki i etyki normatywnej przeprowadzoną przez Davida Hume’a, stało się atrakcyjne nie tylko w Szkocji, ale i na kontynencie, gdzie dominowała wciąż kultura religijna, dla której filozofia szkocka mogła dostarczyć racjonalnego fundamentu, ściśle wpisanego w aktualne dyskusje filozoficzne. Thomas Reid, jej inicjator, upowszechniał ideały epistemologicznego fundamentalizmu,

Wolffa „Krótkiego wykładu o matematycznej metodzie nauczania”, w: Oblicza filozofii XVII wieku, red. S. Janeczek, Lublin 2008, 335-356). Utożsamiając reguły metodyczne filozofii z metodą matematyczną, Wolff stwierdzi: „Nam in methodo philosophica non utendum est terminis nisi accurata defintione explicatis, nec admittitur tanquam verum, nisi quod sufficienter demonstratum, in propositionibus subiectum pariter et praedicatum accurate determinatur et omnia ita ordinantur, ut praemittantur ea, per quae sequentia intelliguntur et adstruuntur". Ch. Wolff, Philosophia rationalis sive logica, methodo scientifica pertractatum ad usum scientiarum atque vitae aptata, Francofurti 1728 (edycja z roku 1740 dokonana przez J. École'a - Hildesheim 1984; cyt. za wydaniem - Francofurti 1740, 69. Zob. S. Janeczek, Logika czy epistemologia? Historycznofilozoficzne uwarunkowania nowożytnej koncepcji logiki, Lublin 2003, 311 n. W szerszym kontekście zob. zwłaszcza H.W. Arndt, Methodo scientifica pertractatum. Mos geometricus und Kalkülbegriff in der philosophischen Theorienbildung des 17. und 18. Jahrhunderts, Berlin 1971; G. Nuchelmans, Judgment and Proposition. From Descartes to Kant, Amsterdam 1983; U. Neemann, Gegensätze und Syntheseversuche im Methodenstreit der Neuzeit, t. 1-2, Hildesheim 1993-1994.

32 W. Tatarkiewicz, O niektórych postaciach racjonalizmu XVII i XVIII wieku, w: Księga pamiątkowa Drugiego Polskiego Zjazdu Filozoficznego, Warszawa 1927; toż w: Tenże, Droga do filozofii, Warszawa 1971, 109-115.

33 Zob. J. Strasser, „Lumen naturale, Sens commun, Common sense”. Zur Prinzipienlehre Descartes', Buffiers i Reids, „Zeitschrift für Philosophie Forschung” 23(1969)2, 178-189. Por. S. Zabieglik, Krzywe zwierciadło filozofii czyli dzieje pojęcia zdrowego rozsądku, Warszawa 1987, 89-99. 
godzącego empiryzm z aprioryzmem, przez osadzenie poznania na niedających się dowieść założeniach, które nazywał zasadami zdrowego rozsądku (first principles, principles of common sense, common notions, self-evident truths), a tezy z nimi sprzeczne uznawał za absurdalne. Niezależnie od tego, czy są one wrodzone czy intuicyjnie bądź instynktownie odczytane ze świata, mają one, zdaniem Reida, źródło w Bogu-Stwórcy natury. Prawda o tym fakcie jest zaś tak pewna, że zbędne jest nawet pytanie jak to sprawił. Nie świadczy to bynajmniej o „słabości ludzkiego poznania, ale decyduje właśnie o jego sile. Założenia te są bowiem raz na zawsze ustalone, a my - choć nie możemy ich dowieść - dysponujemy zdolnością ich odczytania i zrozumienia"34. Wydaje się jednak, że filozofia ta ma bardziej samoistny charakter niż tylko jako funkcjonalnie pojęty fundament etyki, jak w duchu postulatów rozumu praktycznego Kanta interpretuje się nierzadko dokonanie Reida $^{35}$. Był on przecież gorliwym „ministrem Kościoła Szkockiego”, który wykładał w King's College w Aberdeen teologię naturalną, co upoważnia Elmera H. Duncana do nazywania Szkota religious thinker ${ }^{36}$. Nic dziwnego, że filozofia religii Reida stanowiła jeden z trzech fundamentalnych elementów jego dokonania, obok epistemologii i etyki. Nie

34 P. Gutowski, O trzech elementach filozofii Thomasa Reida, Roczniki Filozoficzne 58(2010)1, 80; por. Tamże, 71-93.

35 Życzliwi Reidowi analitycy dopatrują się podobieństw jego dokonania z kantyzmem (T.J. Sutton, The Scottish Kant? A Reassessment of Reid's epistemology, w: The Philosophy of Thomas Reid, red. M. Dalgarno, E. Matthews, Dordrecht 1989, 159-192). Nade wszystko znaczenie jego osiągnięć dostrzega współczesna tzw. reformowana epistemologia (N. Wolterstorff, Thomas Reid and the Story of Epistemology, Cambridge 2001). Nie brak wszakże opracowań z zakresu historii kultury filozoficznej, które wskazują na rozpowszechnienie tego stylu myślenia w całej Europie, także w Niemczech, również w odniesieniu do Kanta (M. Kuehn, Scottish Common Sense in Germany, 1768-1800. A Contribution to the History of Critical Philosophy, Kingston 1987, 167-207; por. B.H. Wójcik, Reid as a pre-Kantian critical philosopher (from the continental point of view), „Journal of Scottish Thought, 2010, t. 3: Reid In His Time and Ours, 177-189).

36 Thomas Reid's lectures on natural theology, wyd. E. Duncan, Washington 1981, xxi-xxii. Zob. S. Zabieglik, Wiek doskonalenia. Z filozofii szkockiego Oświecenia, Zeszyty Naukowe Politechniki Gdańskiej, Filozofia III (1997)558, 234-254. Na temat kultury intelektualnej oświeceniowej Szkocji ugruntowanej na chrześcijaństwie zob. Tamże, 10-93. 
wolno też zapominać, że system ten obejmował także filozofię przyrody z odniesieniami religijnymi, dziedziczoną od Isaaca Newtona ${ }^{37}$. Realia kultury filozoficznej oświeceniowych uniwersytetów odbiegają bowiem daleko od obrazu, który przedstawia podręcznikowa historia epistemologii, dla której następcą Hume’a był Kant ${ }^{38}$; dla przykładu w roku 1766 Reid wykładał w następującej kolejności: pneumatologię, teologię naturalną i filozofię polityki ${ }^{39}$, a więc kontynuował wizję filozofii pojętej integralnie (maksymalistycznie).

Jak pododaje Dale Tuggy, badający notatki z zajęć prowadzonych przez Reida w roku 1780, jego wykłady z pneumatologii były ,clearly inspired by the first chapter of Joseph Butler's Analogy"40. Formułował bowiem wyrazistą wizję struktury ontycznej człowieka, zwłaszcza w odniesieniu do substancjalistycznie ujętego wymiaru duchowego ${ }^{41}$. Jeszcze wyraziściej metafizyczny wymiar rozważań Reide’a ujawnił się w prowadzonych przez trzydzieści lat (1751-1780) wykładach z zakresu teologii naturalnej. Chociaż Reid ,continually emphasizes the limits of human understanding”, to przecież ,he doesn't hesitate to employ the

37 R. Nichols, G. Yaffe, Thomas Reid, w: The Stanford Encyclopedia of Philosophy, http://plato.stanford.edu/entries/reid/ [dostęp 1.09.2015]. Por. D. Tuggy, Reid's Philosophy of Religion, w: The Cambridge Companion to Thomas Reid, red. T. Cuneo, R. van Woudenberg, Cambridge 2004, 289-312; R. Nichols, R. Callergård, Thomas Reid on Reidian Religious Belief Forming Faculties, Modern Schoolman 88(2011), 317-335; D.B. Wilson, Seeking Nature's Logic. Natural Philosophy in the Scottish Enlightenment, Pennsylvania 2009, 103-132.

38 Por. M.A. Stewart, The curriculum in Britain, Ireland end the Colonies, w: The Cambridge History of Eighteenth-Century Philosophy, t. 1, red. K. Haakonssen, Cambridge 2011, 97-120.

39 Anonymous, Reid's Essays 17661767, Aberdeen University Library MS 2131/8/ VII. Cyt. za: D. Tuggy, dz. cyt., 307.

40 G. Baird, Notes from the Lectures of Dr. Thomas Reid, MS A104929, 8 vol., Mitchell Library, Glasgow. Cyt. za: D. Tuggy, dz. cyt., 308.

${ }^{41} \mathrm{Na}$ temat metafizycznej antropologii Butlera skonstruowanej w perspektywie życia przyszłego, bo w rozdziale zatytułowanym Offuture Life, w tomie The Analogy of Religion, Natural and Revealed, to the Constitution and Course of Nature (London 1736; wyd. współczesne ze wstępem Ernesta C. Mossnera, New York 1961); zob. I. Ziemiński, Moralność i religia. Poglady filozoficzne Josepha Butlera, Warszawa 2002, 196-207. 
tools of philosophy in matters religion”42. Jego „rationalistic apologetics”, niechętna wzorom średniowiecznym, zakorzeniona była w teistycznie interpretowanej myśli Newtona, zwłaszcza zaś w apologetyce Samuela Clarke'a ${ }^{43}$ i wspomnianego Josepha Butlera. Nic dziwnego, że „Reid's lectures follow an ancient pattern, treating the existence, attributes, and works of God"44. W pierwszym przypadku szkocki filozof formułował następujące argumenty za istnieniem Boga: ,(1) a cosmological argument, (2) a design argument, (3) an argument from the nearly unanimos consent of human everywhere through the ages, (4) an argument from empirical evidence that the world is not eternal, and (5) an argument from miracles"45. Tuggy podsumowując jednoznacznie metafizyczną osnowę argumentacji Reida, przywołuje jego wypowiedź z wykładów z roku 1766: „Concerning these five Reid pronounces (in a Clarkean tone), "All which being put together amount to an Absolute certainty and Demonstration that there is a first Cause possessed of all possible perfections, who must have Existed from all Eternity «"46. Nietrudno dostrzec, że była to filozofia Boga spotykana powszechnie w oświeceniowym szkolnictwie, w którym podejście metafizyczne łączyło się z fizykalistycznym, a także historycznym, służąc wyraziście ówczesnej apologii wiary. Dostosowując argumentację do ówczesnej mentalności kształtowanej coraz bardziej przez nowożytną empiryczną science, splatano eklektycznie nowszy argument kosmologiczny z tradycyjnym podejście teleologicznym ${ }^{47}$. Apologetyczny wymiar tych rozważań ujawniania się jeszcze bardziej w rozważaniach dotyczących istoty Boga, gdy Reid wyróżni, także w sposób typowy dla oświeceniowych podręczników filozofii, atrybuty naturalne i moralne, w pierwszym przypadku - jak jednym tchem wskazuje Tuggy - przymioty wskazywane przez tradycyjną filozofię chrześcijańską, jak „eternity (everlastingness, not timelessness), necessity, independence, immensity (omnipresence),

42 D. Tuggy, dz. cyt., 289.

${ }^{43}$ Zob. S. Raube, Metafizyka i etyka Samuela Clarke'a, Białystok 2010.

44 D. Tuggy, dz. cyt., 289.

45 D. Tuggy, dz. cyt., 291.

46 D. Tuggy, dz. cyt., 291.

47 Zob. S. Janeczek, Filozofia Boga w okresie oświecenia, Zeszyty Naukowe Katolickiego Uniwersytetu Lubelskiego 32(1989)1-4(125-128), 29-48. 
unlimited power, unlimited perfection, perfect knowledge and wisdom, spirituality, unity (uniqueness), and immutable happiness", gdy w drugim wyraźnie inspirowane przez objawienie biblijne, skoro są to: „goodness, mercy, forbearance, veracity, love of virtue, hatred of vice, justice, and freedom" ${ }^{48}$.

Trudno więc uznać dokonanie Reida, którego elementem są rozważania metafizyczne za przejaw ,agnostycyzmu w obrębie teizmu”49, natomiast nie dziwi dlaczego to nie twórczość Hume’a, stanowiąca przejaw agnostycyzmu religijnego, znalazła posłuch w oświeceniowym szkolnictwie tyleż szkockim czy na kontynencie, ale twórczość „myślicieli bardziej umiarkowanych, którzy akceptując nowożytną naukę i część filozofii, starali się zablokować sceptyczne konsekwencje w odniesieniu do religii i instytucji społecznych, gwarantujących stabilność porządku moralnego, politycznego i edukacyjnego. Ich liderem był właśnie Thomas Reid, twórca tzw. szkockiej szkoły zdrowego rozsądku. Umiar w łączeniu nowych idei z tym, co stare i sprawdzone, okaże się bardzo atrakcyjną cechą jego filozofii. Zadecyduje on w dużej mierze o wpływach Reida w różnych krajach Europy (w tym także w Polsce) i w USA. Wielu bowiem myślicieli tego czasu gotowych będzie zanurzyć się w ożywczych nurtach Oświecenia, ale pod warunkiem, że po kąpieli staną na twardym gruncie dobrze sprawdzonych przekonań"50.

Kartezjusz był przeciwny ugruntowanej na zdroworozsądkowym fundamencie filozofii przyrody Arystotelesa ${ }^{51}$, którą chciał zastąpić

48 D. Tuggy, dz. cyt., 301. Zob. F. Bargieł, Stanisław Szadurski SJ (1726-1789). Przedstawiciel uwspółcześnionej filozofii scholastycznej, Kraków 1978, 196-197; por. Tamże, 183-199.

49 „Agnostycyzm w obrębie teizmu” odniesie Gutowski do rozważań o „charakterze metafizyczno-epistemologicznym", stąd słusznie oponuje przeciwko charakterystycznemu dla M. Hempolińskiego, najbardziej zasłużonego na gruncie polskim w badaniach na Reide'm, ,pomniejszeniu - niesłusznie - znaczenia wątków religijnych w jego myśli”. P. Gutowski, O trzech elementach filozofii Thomasa Reida, dz. cyt., 72; por. Tamże, 86-91.

50 Tamże, 71-72.

${ }^{51}$ Zdrowy rozsądek traktowany jest w tradycji arystotelesowskiej jako „baza poznawcza", stanowiąca przejaw poznania potocznego, zalążek krytycznego poznania naukowego. Obejmuje ona ,a) dane poznawcze związane z codziennym doświadczeniem, opartym na percepcji zmysłowej; b) niektóre czysto rozumowe oczywistości 
nowożytną science w duchu Galileusza ${ }^{52}$. Głosił programowy krytycyzm, który miał być warunkiem zbudowania wiedzy pewnej, różnej od charakterystycznej dla nowożytnego arystotelizmu chrześcijańskiego kultury autorytetu, przekonanej o trwałości nauki starożytnej, wyczerpującej się w dyskusjach na temat koherencyjnie pojętego arystotelizmu („wiedza książkowa"53), którą chciał zastąpić badaniem przyrody dla niej samej ${ }^{54}$. Niemniej - jak to zasygnalizowano wyżej - jego dokonanie

poznawcze; c) konieczne konsekwencje oczywistości poznawczych zmysłowych i rozumowych”, których „nie trzeba uzasadniać komukolwiek”, np. że „,całość jest większa od swej części, że każda rzecz jest sobą, a nie czymś drugim, że człowiek zachowuje tożsamość, wskutek czego można go wynagradzać i karać za czyny minione, że »to, co jest - jest«, a »czego nie ma - nie ma« itd.”. Można widzieć w tym zalążkowo ujęte zasady poznania i bytu, ale także ,podstawowe zasady moralności i ludzkiego zachowania”. M.A. Krąpiec, Elementy filozofii poznania, w: M.A. Krąpiec $\mathrm{i}$ in., Wprowadzenie do filozofii, Lublin 1992, 214. Por. Tamże, 214-221; Tenże, Realizm ludzkiego poznania, Lublin 1995², 61-84.

52 Por. W. Sady, Dlaczego „Rozmowy i dowodzenia matematyczne” Galileusza sa naukowe, a „Świat” Kartezjusza nie?, w: Pogranicza nauki. Protonauka-paranauka-pseudonauka, red. J. Zon, Lublin 2009, 87-100; T. Śliwiński, Ratio et physis. Fizyka teoretyczna Kartezjusza jako realizacja projektu mathesis universalis, Nowa Wieś 2005.

53 R. Descartes, Discours de la méthode pour bien conduire sa raison et chercher la verité dans les sciences, Leyde 1637; toż w wyd. É. Gilsona jako: Discours de la Méthode. Texte et commentaire, Paris 1925; cyt. jako: Rozprawa o metodzie właściwego kierowania rozumem i poszukiwania prawdy w naukach, tłum. z franc. W. Wojciechowska, Kraków 1950, Warszawa 1988³, 12, 16-18, 78-88; cyt. jako Discours de la méthode, w: Euvres de Descartes, wyd. Ch. Adam, P. Tannery, Paris 1897-1913; repr. Paris 1996, t. 6, 9-10, 12-15, 68-78.

54 Arystotelesowska 'empiria' nie była „doświadczeniem zorganizowanym metodycznie, lecz doświadczeniem, które kształtuje się w ciągu całego życia, które nie jest związane z żadnym szczególnym uprzywilejowanym aktem, i które ma znaczenie raczej praktyczne niż naukowe". Cyt. za: M. Heller, Filozofia świata. Wybrane zagadnienia i kierunki filozofii przyrody, Kraków 1992, 37. O ile historycy nauki są zgodni, że nauka średniowieczna była przygotowaniem podstaw pod rozwój wiedzy nowożytnej, to trwa dyskusja, czy nauka nowożytna była kontynuacją średniowiecza (np. P. Duchem, E. Dijksterhuis, A. Crombie), czy miała charakter swoisty (np. M. Clagett, A. Maier). Za: E. Jung-Palczewska, Między filozofia przyrody a nowożytnym przyrodoznawstwem. Ryszard Kilvington i fizyka matematyczna wśredniowieczu, Łódź 2002, 268-291, gdzie autorka wydaje się wypowiadać w kategoriach Th. Kuhna o „niewspółmierności” dokonań średniowiecznych i nowożytnych wbrew kumulatywnemu rozumieniu rozwoju 
wpisuje się w jakiejś mierze w nurt podtrzymujący zdroworozsądkowe rozumienie lumen naturale, zakorzenione w różnej formie w filozofii starożytnej i średniowiecznej ${ }^{55}$. Kartezjusz był bowiem przekonany o właściwej wszystkim ludziom wrodzonej zdolności umysłu (ingenium, esprit) odróżniania prawdy od fałszu, którą nazywał zdrowym rozsądkiem (bon sens, sanus sens), prawym umysłem (bona mens), rozumem (raison) ${ }^{56}$ czy też tradycyjnie brzmiącym przyrodzonym światłem rozumu (lumen naturale rationis, lumière naturelle), „który każdemu człowiekowi dany jest przez naturę"57. Edmund Morawiec słusznie zwraca

nauki, co związane było z rolą, jaką uczeni średniowieczni przypisywali tekstom Arystotelesa, pisząc w istocie jedynie glosy do jego traktatów, gdy nowożytność powróciła znów do księgi natury, choć nie brak przykładów, że teoretyczne rozważania późnoscholastycznych filozofów przyrody operujących językiem matematyki, także na gruncie francuskim (Mikołaj Oresme, a następnie Albert z Saksonii i Marsyliusz z Inghen), były prowadzone na gruncie fizyki teoretycznej, a nie tylko na poziomie metafilozoficznym, jak w przypadku J. Burydana. Por. E. Jung-Palczewska, Procedura secundum imaginationem w czternastowiecznej filozofii przyrody, w: Ksiega pamiątkowa ku czci Profesora Zdzisława Kuksewicza, red. E. Jung-Palczewska, Łódź 2000, 57-79. Por. S. Janeczek, Geneza nowożytnego arystotelizmu chrześcijańskiego, w: Oblicza filozofii XVII wieku, dz. cyt., 477-512.

55 Zob. np. F.H. Sardemann, Ursprung und Entwicklung Der Lehre von Lumen Rationis Aeternae, Lumen Divinum, Lumen Naturale, Rationes Seminales, Veritates Aeternae bis Descartes, Kassel 1902. Por. S.H. Daniel, Descartes' Treatment of 'lumen naturale', Studia Leibnitiana 10(1978)1, 92-100; S. Gregory, Lumen naturale Licht und Wahrheit bei Descartes, Zeitschrift für Kulturphilosophie 8(2014)2, 261-278; D. Jacquette, Descartes' Lumen Naturale and the Cartesian Circle, Philosophy and Theology: Marquette University Quarterly 9(1996), 273-320; J. Morris, Descartes' Natural Light, Journal of the History of Philosophy 11(1973)2, 169-187.

56 R. Descartes, Rozprawa o metodzie, dz. cyt., 4; Tenże, Discours de la méthode, dz. cyt., 2; Tenże, La Recherche de la vérité par la lumière naturelle, Amstelodamii 1701; cyt. jako: La Recherche de la vérité, w: Euvres de Descartes, dz. cyt., t. 10, 500; Tenże, Poszukiwanie prawdy poprzez światło przyrodzone rozumu, w: Tenże, Prawidta kierowania umysłem. Poszukiwanie prawdy poprzez światło przyrodzone rozumu, tłum. z franc. L. Chmaj, Warszawa 1937, 1958², 115-155.

57 Uzasadnieniem powszechnego wyposażenia intelektualnego ma być „powszechny pogląd filozofów", w szczególności, co zdradza frazeologia wypowiedzi, tradycja arystotelesowska, zróżnicowanie bowiem w tym zakresie ma mieć tylko charakter „stopnia”, czyli „,cech przypadkowych” (accidens), a nie cech gatunkowych, czyli ich „form” lub „,natur”. R. Descartes, Rozprawa o metodzie, dz. cyt., 4; Tenże, Discours de 
uwagę na szeroki zakres kompetencji owego ,zdrowego rozsądku”, od sfery teoretycznej (naukowej) do umiejętności praktycznych, użytkowych i moralnych ${ }^{58}$. „Rozsądek jest rzeczą najsprawiedliwiej rozdzieloną na świecie” czy też ,zdolnością [puissance, dod. - SJ] poprawnego sądzenia i odróżniania prawdy od fałszu [która - SJ] jest z natury swej jednakowa u wszystkich ludzi”59, stąd ,do odkrycia nawet prawd najtrudniejszych, byle tylko prowadzono nas należycie, potrzebny jest jedynie tzw. chłopski rozum [sensus communis, dod. - SJ]" ${ }^{60}$, a nawet zdrowy rozsądek, utożsamiany z ,prostym, nieuczonym rozumowaniem rozsądnego człowieka"61.

We wczesnych dziele, jakim jest Poszukiwanie prawdy poprzez światło przyrodzone rozumu, Descartes obiecywał pompatycznie, iż sam rozum obdarzony światłem naturalnym (lumière naturelle), a więc bez kształcenia, może zdobyć wszelką wiedzę, byle poznał i posługiwał się właściwą metodą poznania ${ }^{62}$. Dopiero jednak w następnych pracach

la méthode, dz. cyt., 2-3. Zob. S. Zabieglik, Krzywe zwierciadło filozofii czyli dzieje pojęcia zdrowego rozsądku, dz. cyt., 89-99.

58 E. Morawiec podkreśla szeroki zakres kompetencji zdrowego rozsądku w kontekście definicji epistemologicznie zorientowanej filozofii, jako studium praktycznie pojętej mądrości (étude de la sagesse - w liście do ks. C. Picot, tłumacza Zasad filozofii, w: R. Descartes, Les Principes de la philosophie, tłum. z franc. C. Picot, Paris 1647; cyt. w wyd. Euvres de Descartes, t. 9, cz. 2, 10; toż, Zasady filozofii, tłum. z franc. I. Dąmbska, Warszawa 1960, 355). Jest ona przejawem roztropności (prudence) w działaniu obejmującym sferę poznania, czyli szeroko pojęte umiejętności (arts) i kierowania życiem (conduit de la vie). Bona mens jest w istocie universale sapientia. R. Descartes, Regulae ad directionem ingenii. Amstelodamii 1701; cyt. w wyd. Euvres de Descartes, dz. cyt., t. 10, 360; toż jako: Prawidta kierowania umysłem, w: Tenże, Prawidła kierowania umysłem. Poszukiwanie prawdy poprzez światło przyrodzone rozumu, tłum. z łac. L. Chmaj, Warszawa 1937, 1958², 4. Zob. E. Morawiec, Przedmiot a metoda w filozofii Kartezjusza, Warszawa 1970, 15-20.

59 R. Descartes, Rozprawa o metodzie, dz. cyt., 3; Tenże, Discours de la méthode, dz. cyt., 2 .

${ }_{60}$ Tenże, Poszukiwanie prawdy, dz. cyt., 140; Tenże, La Recherche de la vérité, dz. cyt., 518 .

${ }_{61}$ Tenże, Rozprawa o metodzie, dz. cyt. 12, 16-18, 78-88; Tenże, Discours de la méthode, w: Euvres de Descartes, dz. cyt., t. 6, 9-10, 12-15, 68-78.

62 Postulując określenie metody, przy pomocy której „umysł przeciętny będzie mógł sam z własnej mocy wynaleźć to wszystko, co odkrywają umysły najbardziej 
wskazał bliżej, czym jest to światło naturalne ${ }^{63}$. W Rozprawie o metodzie, domagając posługiwania się właściwą władzą sądzenia (mon propre jugement), stwierdzał, że „Bóg dał każdemu z nas pewne światło dla odróżniania prawdy od fałszu" ${ }^{4}$. Tak pojęte światło naturalne pozwala w sposób niepowątpiewalny, a więc w sposób nieporównywalny $\mathrm{z}$ innymi rodzajami poznania, odróżniać prawdę od fałszu ${ }^{65}$. Błąd jest więc wyrazem ,zaciemnienia światła naturalnego i osłabienia naszej zdolności pojmowania”. Jest jednak przezwyciężalny, jeśli usunie się brak krytycyzmu i będzie się posługiwać właściwą metodą ${ }^{66}$.

Metoda ta odwołuje się do standardów matematyki ${ }^{67}$ scalającej intuicję z dedukcją, traktowaną jednak jako ciąg aktów intuicji intelektualnej spełniającej wymóg immanentnej oczywistości pojętej w sensie podmiotowym, bo za prawdę przyjmuje się jedynie to, co jawi się jako

subtelne”, Descartes stwierdzał, że „umysł zdrowy [bon esprit, dod. - SJ], wychowany nawet na pustyni i nie mający nigdy innego światła prócz naturalnego (lumière que celle de la nature, dod. - SJ), musiałby dojść do tych samych poglądów, co wasze, gdyby dobrze rozważył wszystkie te same racje”. R. Descartes, Prawidła kierowania umysłem, dz. cyt., 127; Tenże, Regulae ad directionem ingenii, dz. cyt., 500.

63 J. Kopania, Funkcje poznawcze Descartesa teorii idei, Białystok 1988, 171; por. Tamże, 169-179.

64 R. Descartes, Rozprawa o metodzie, dz. cyt., 32; Tenże, Discours de la méthode, dz. cyt., 27.

65 R. Descartes, Meditationes de prima philosophia, Parisiis 1641; cyt. za wyd. Euvres de Descartes, dz. cyt., t. 7, 38-39; toż jako: Medytacje o pierwszej filozofii wraz z zarzutami uczonych mężów i odpowiedziami autora oraz rozmowa z Burmanem, t. 1-2, tłum. z franc. M. i K. Ajdukiewiczowie, S. Swieżawski, I. Dąmbska, Warszawa 1958, Kęty 2001, t. 1, 50.

66 R. Descartes, Rozprawa o metodzie, dz. cyt., 12; Tenże, Discours de la méthode, dz. cyt., 10 .

${ }^{67}$ Budując zasady metody gwarantującej poznanie o charakterze odkrywczym, a przy tym odznaczające się wymogiem pewności, Kartezjusz - przynajmniej początkowo - ograniczył się do postulatu powszechnego wykorzystania metody stosowanej w matematyce, która jako jedyna osiągnęła zalecane standardy metodologiczne. Zob. E.G. Salamon, Mathematical Roots of Cartesian Metaphysics, The New Scolastiscism 39(1965), 158-169; E. Morawiec, Przedmiot a metoda w filozofii Kartezjusza, dz. cyt., 80-86; J. Dadaczyński, Filozofia matematyki, Tarnów 2000, 100-139; Por. E.R. Grosholz, Cartesian Method and the Problem of Reduction, Oxford 1991; J. Vuillemin, Mathématique et métaphysique chez Descartes, Paris 1960. 
jasne i wyraźne. Ma być zaś użyteczna zarówno w odniesieniu do akceptacji najprostszych prawd (aksjomatów) na drodze analityczno-redukcyjnej, jak i w tworzeniu ciągów myślowych odznaczających się także wymogiem oczywistości. Zasadniczy charakter odgrywa jednak poznanie intuicyjne, ów akt „czystego umysłu”, który wymaga prostoty ujmowanego przedmiotu, tak aby się jawił umysłowi na tyle wprost, odosobniony, odsłonięty, aby można go było dotknąć umysłem (mente attingere), jak sugeruje np. opis wglądu (inspectio) umysłu, przyrównywanego do fizycznych czynności widzenia czy dotyku ${ }^{68}$. W tym kontekście ujawnia się nawet swoiście biologistyczny charakter intuicji porównywanej do instynktu, który budził coraz większe zainteresowanie nowożytnych uczonych ${ }^{69}$. Obok instynktu właściwego zwierzętom i ludziom w wymiarze cielesnym, Descartes wyróżniał instynkt, który jest tylko w ludziach, ,jest on czysto intelektualny: to światło naturalne, intuitus mentis, dzięki któremu wiem, że trzeba sobie ufać"70.

$\mathrm{Z}$ wymogiem prostoty przedmiotu intuicji koresponduje koncepcja tzw. natur prostych (naturae simplices), którą sformułował Kartezjusz zwłaszcza w Prawidłach, powiązana następnie z teorią idei wrodzonych zawartą w Medytacjach o pierwszej filozofii. Ma ona fundament ontyczno-epistemiczny w formie tzw. prawd wiecznych warunkujących z kolei owo naturalne światło rozumu ${ }^{71}$. Koncepcja ta jest ściśle związana z aprioryzmem kartezjańskim, uzasadniającym możliwość poznania

68 R. Descartes, Medytacje o pierwszej filozofii, dz. cyt., 54; Tenże, Meditationes de prima philosophia, dz. cyt., 31. Zob. uwagi É. Gilsona w: R. Descartes, Discours de la Méthode. Texte et commentaire, dz. cyt., 198; A. Gewirth, Clearness and Distinctness in Descartes, w: Descartes, red. J. Cottingham, Oxford 1998, 79-100.

69 Zob. np. T. Stegliński, Pierre Chanet, polemista i filozof instynktu, oraz Marin Cureau de la Chambre - historia pewnego sporu, Roczniki Filozoficzne 63(2015), 65-84.

70 R. Descartes, List do Mersenne'a z 16 października 1639 r., w: Euvres de Descartes, dz. cyt., t. 2, 599.

71 Zob. J.-L. Marion, Cartesian Metaphysics and the Role of the Simple Natures, w: The Cambridge Companion to Descartes, red. J. Cottingham, Cambridge 1992, 115-139; B.E. O'Neil, Epistemological Direct Realism in Descartes' Philosophy, Albuquerque 1974, 13-33; S. Gaukroger, Cartesian Logic. An Essay on Descartes's Conception of Inference, Oxford 1989, rozdz. 2, 60 nn.; H.G. Frankfurt, Descartes on the Creation of the Eternal Truths, Philosophical Review 86(1977), 36-57; E. Curley, Descartes on 
rzeczy niezależnie od doświadczenia, które poprzedza i przekracza ${ }^{72}$. Przejawem tego aprioryzmu jest z kolei koncepcja idei wrodzonych, która zakłada tożsamość (czy należałoby raczej powiedzieć - izomorfizm) natury umysłu i bytu. Jak lapidarnie stwierdza Jerzy Kopania, Kartezjusz sytuował przedmiot poznania wewnątrz umysłu ludzkiego, stąd idea stanowiła nie tylko przedmiot (bezpośredni) poznania, ale i warunek konieczny możliwości poznania i zasadę wyjaśniającą proces poznawczy ${ }^{73}$. Nie można wszakże zapominać o boskim pochodzeniu idei. Rozpoznaje je umysł ludzki analogiczny w swym działaniu do

the Creation of the Eternal Truths, Philosophical Review 93(1984), 569-597; A. Kenny, The Cartesian Circle and the Eternal Truths, Journal of Philosophy 67(1970), 685-700.

72 Potencjalny charakter wyposażenia apriorycznego nie wyklucza roli doświadczenia w konstytuowaniu idei w ludzkim umyśle. Zob. K. Wawrzonkowski, O spostrzeżeniach zmystowych i ideach nabytych w filozofii Kartezjusza, Roczniki Filozoficzne 63(2015)1, 49-64; A. Głąb, Kartezjańska koncepcja zjednoczenia umysłu i ciała - na podstawie interpretacji Margaret D. Wilson, Roczniki Filozoficzne 58(2010)1, 27-50. W odniesieniu do wątków empirystycznych na gruncie przyrodoznawstwa zob. S. Janeczek, O trudnościach kategorializacyjnych w historii nowożytnej teorii nauki. Opozycja: racjonalizm - empiryzm, w: Leibniz. Tradycja i idee nowoczesnej filozofii, red. B. Paź, Kraków 2010, 135-151.

73 J. Kopania zwraca słusznie uwagę, że w metafizycznie nastawionych Medytacjach o pierwszej filozofii, w odróżnieniu od Prawideł kierowania umysłem, skupionych na wypracowaniu uniwersalnej metody, Kartezjusz odchodzi od operowania kategoriami natur prostych, zastępując je pojęciami pierwotnymi, a nadto te ostatnie są rozumiane inaczej niż pierwsze. Jedyną ich modyfikacją jest wszakże pozostawanie na płaszczyźnie wewnątrzumysłowej, bez odniesień do rzeczywistości zewnętrznej, co sprowadza proces poznania jedynie do poprawnego posługiwania się pojęciami pierwotnymi, dbając o to, by pojęcia te „dobrze rozróżniać i by każde z nich przypisywać tylko tym rzeczom, do których one się stosują". R. Descartes, Listy do księżniczki Elżbiety, tłum. z franc. J. Kopania, Warszawa 1995, 5; Euvres de Descartes, dz. cyt., t. 3, 665-666. Troska o oczywistość ujęcia idei, dokonującego się w sposób jasny i wyraźny, sprawia, że nawet wrażenia zmysłowe ujmujemy jasno i wyraźnie, gdy bierze się je jako wrażenia zmysłowe, a nie traktuje się jako rzeczy istniejące poza umysłem (R. Descartes, Zasady filozofii, dz. cyt., 41-43; Tenże, Principia philosophiae, dz. cyt., 32-34). Osiągnięcie poznania zupełnego (intellectio completa) jest charakterystyczne dla ludzkiego poznania intelektualnego, różnego od poznania adekwatnego (cognitio adaequata), dostępnego jedynie Bogu - ma bowiem rację w samym umyśle, co tłumaczy ścisły związek między zupełnością a jasnością i wyraźnością idei ujmowanych przez umysł. R. Descartes, Medytacje o pierwszej filozofii, dz. cyt., 192-197; Tenże, Meditationes de 
umysłu Bożego, na którego wzór został stworzony. Idee, przez które człowiek ujmuje rzeczywistość, mają więc swój fundament w formach ujmowania dokonywanego przez umysł Boży ${ }^{74}$. Koncepcja ta, zwłaszcza gdy odwołuje się do wspomnianych prawd wiecznych, ma rodowód nie tyle w tradycji platońskiej, jak chce szkoła marburska ${ }^{75}$, ale w tradycji scholastycznej - jako modyfikacja rozwiązań św. Tomasza z Akwinu, jak chce Kopania ${ }^{76}$ - a ostatecznie jej fundament tkwi w egzemplaryzmie św. Augustyna, na co wskazuje słusznie Morawiec, powołujący się na Émile’a Bréhiera i Étienne’a Gilsona ${ }^{77}$.

Szczególną formą idei wrodzonych są prawdy wieczne (aeternae veritates), określane też jako communae notiones, a więc prawdy wyrażone w najbardziej ogólnych i oczywistych sądach, charakterystycznych dla każdej dziedziny przedmiotów, a nawet dla poszczególnych dziedzin rzeczywistości i odpowiadających im dyscyplin. Najczęściej Kartezjusz odnosił je do prawd matematycznych ${ }^{78}$, ale także do fizycznych czy metafizycznych. Wskazuje nawet, że są one „niezliczone, których jednak nie można wszystkich łatwo wymienić, ale o których też powinno

prima philosophia, dz. cyt., 220-227. Zob. J. Kopania, Funkcje poznawcze Descartesa teorii idei, dz. cyt., 254-261.

${ }^{74}$ R. Descartes, Medytacje o pierwszej filozofii, dz. cyt., 165; Tenże, Meditationes de prima philosophia, dz. cyt., 181. Aprioryzm Kartezjański, jak to lapidarnie stwierdza J. Kopania, sytuował przedmiot poznania wewnątrz umysłu ludzkiego, stąd idea stanowiła nie tylko przedmiot (bezpośredni) poznania, ale i warunek konieczny możliwości poznania i zasadę wyjaśniającą proces poznawczy. J. Kopania, Funkcje poznawcze Descartesa teorii idei, dz. cyt., 181.

${ }_{75}$ Zob. M. Czarnawska, Über die Entstehung und Bedeutung das Wortes ,idéa”, w: Studies in Logic, Grammar and Rhetoric, t. 4, Białystok 1984; toż jako: Czy idea jest ajdosem, Studia Filozoficzne 29(1985)8-9, 163-167.

76 J. Kopania, Funkcje poznawcze Descartesa teorii idei, dz. cyt., 179-189.

77 E. Morawiec, Przedmiot a metoda w filozofii Kartezjusza, 72. Por. E. Bréhier, La Creation des vérités éternèlles dans le système de Descartes, Revue de Philosophie de la France et de l'Etranger 62(1937), 16-29; É. Gilson w: R. Descartes, Discours de la Méthode. Texte et commentaire, dz. cyt., 335.

${ }^{78}$ Kartezjusz stwierdza, że mamy nie tylko idee liczby czy kształtów, ale także communae notiones, które mają formę sądów, jak o tym świadczy przykład: ,jeśli do wielkości sobie równych dodasz równe, te, które z nich powstaną, będą też sobie równe". R. Descartes, Zasady filozofii, dz. cyt., 13; Tenże, Principia philosophiae, dz. cyt., 9 . 
się wiedzieć, kiedy zdarzy się sposobność, abyśmy o nich myśleli i nie dawali się zaślepiać przesądom"79. Prawdy te są jednocześnie podstawą stałości i niezmienności zasad i istnienia wszechrzeczy, są więc prawami natury $^{80}$. Odkrywamy je w umyśle dzięki światłu naturalnemu ${ }^{81}$. Co więcej, niepodobna ich nie odkryć, bez uprzedzeń, i to w sposób oczywisty, choć nie przez wszystkich są w równym stopniu poznawane ${ }^{82}$. Szeroki zakres tych prawd, a także ich wrodzonej specyfiki, nie musi być tłumaczony w sensie ścisłym. Kartezjusz zalicza bowiem do nich także te, które stanowią ich proste konsekwencje, zwłaszcza jeśli się zwróci uwagę na pierwotny charakter prawd metafizycznych, a nawet podstawowy charakter twierdzenia dotyczącego istnienia podmiotu myślenia (cogito ergo sum) oraz istnienia Boga, a następnie uprawomocnienia naszych percepcji zmysłowych dotyczących istnienia świata materialnego, co jest warunkiem kolejnego wyprowadzania wszystkich zasad fizyki ${ }^{83}$. Uwidacznia się to najbardziej w formie postulowanego przez Kartezjusza systemu swoiście dedukcyjnego, w którym obok reguł wiedzotwórczych występowały dwa podzbiory zdań w formie ,pierwszych przyczyn i zasad” oraz wydedukowanych z nich twierdzeń ${ }^{84}$. W skład tego apriorycznego wyposażenia, które przynajmniej po części przypomina rozwiązania charakterystyczne dla szkockiej

79 Np. „To samo nie może być i nie być zarazem... Ten kto myśli nie może nie istnieć, podczas gdy myśli". R. Descartes, Principia philosophiae, Amstelodamii 1644; cyt w wyd. Euvres de Descartes, t. 8, cz. 1, 9; Tenże, Zasady filozofii. Por. Tenże, Zasady filozofii, dz. cyt., 49; Tenże, Principia philosophiae, dz. cyt., 389.

${ }^{80}$ Tenże, Rozprawa o metodzie, dz. cyt., 49-50; Tenże, Discours de la méthode, dz. cyt., 41 .

81 Wprost sens commun, traktowany jako zdrowy rozsądek, utożsamiał z bon sens i z notiones communes już François Fenelon (Traité de l'existence de Dieu, Paris 1713), co przywoływał Th. Reid, Essays on the Intellectual Powers of Man, Edinburgh 1875; repr. Menston 1971; toż jako: Rozważania o władzach poznawczych człowieka, tłum. z ang. M. Hempoliński, Warszawa 1975, 519-520.

82 R. Descartes, Zasady filozofii, dz. cyt., 31; Tenże, Principia philosophiae, dz. cyt., 24.

83 Tenże, Rozprawa o metodzie, dz. cyt., 49 nn.; Tenże, Discours de la méthode, dz. cyt., $41 \mathrm{nn}$.

${ }_{84}$ Zob. E. Morawiec, Przedmiot a metoda $w$ filozofii Kartezjusza, dz. cyt., 27-29. 
filozofii zdrowego rozsądku (prawdy konieczne i prawdy przygodne) ${ }^{85}$, w pierwszym przypadku wchodziły zasady niesprzeczności, przyczynowości i racji dostatecznej, a w drugim - zdanie stwierdzające istnienie własnej duszy ${ }^{86}$.

\section{EPISTEMOLOGIA PASCALA}

Ogarnięty wizją nowej wiedzy Kartezjusz koncentrował się na odkryciu prawdy, ufając, że przezwycięży jałowość scholastycznej i renesansowej kultury autorytetu, gdy sformułuje nową metodę, co ujmował dramatycznie w prawidle IV Regulae ad directionem ingenii: „Do badania prawdy konieczna jest metoda... I o wiele właściwiej jest nigdy nie myśleć o poszukiwaniu prawdy jakiejś rzeczy, niźli to czynić bez metody; jest to bowiem zupełnie pewne, że wskutek takich bezładnych studiów i ciemnych dociekań przyrodzone światło ulega zamąceniu,

85 Jak wiadomo, zdaniem Reida w strukturę umysłu są wpisane - na zasadzie jego konstytucji - podstawowe dla poznania ludzkiego przekonania, wspólne wszystkim normalnym ludziom. Stanowią one warunek wszelkiego poznania. Te pierwotne przeświadczenia dzieli na pierwsze zasady prawd przypadkowych i pierwsze zasady prawd koniecznych. Reid wybrał 12 pierwszych zasad przypadkowych, dotyczących prawd faktualnych, tak, by stanowiły one przeciwieństwo tez Kartezjusza (np. „naturalne władze, za pomocą których odróżniamy prawdę od fałszu, nie zwodzą"), Berkeleya (np. „rzeczy, które spostrzegamy wyraźnie, istnieją rzeczywiście i są takie, jakimi je spostrzegamy”) czy Hume’a (np. „,myśli, których jestem świadomy, są myślami bytu, który nazywam: »Ja«, »Mój umysł«, moja »osoba«"). Zasady te mają gwarantować realizm poznawczy i w miejsce reprezentacjonizmu - w odróżnieniu od Kartezjusza sankcjonować prezentacjonizm, umożliwiają bowiem bezpośredni i wiarygodny kontakt z rzeczywistością pozapodmiotową. Th. Reid, Rozważania o władzach poznawczych czlowieka, dz. cyt., 575-603. W odniesieniu do prawd koniecznych Reid ograniczył się do wyróżnienia ich sześciu klas tak, by usankcjonować zarówno prawomocność nauk formalnych, jak i realnych; są to zasady: gramatyki (np. „każde zdanie pełne musi mieć orzeczenie"), logiki (np. zasada niesprzeczności), matematyki (np. pewniki Euklidesa), estetyki (np. ,twarz ludzka pozbawiona nosa lub oka albo z wykrzywionymi ustami nie jest piękna”), etyki (np. ,,czyn niesprawiedliwy jest większym przewinieniem niż czyn nieszlachetny”) i metafizyki (z fundamentalną zasadą przyczynowości - „wszystko, co zaczyna istnieć, musi mieć swą przyczynę"). Tamże, 603-636. Zob. S. Zabieglik, Krzywe zwierciadto filozofii czyli dzieje pojęcia zdrowego rozsądku, dz. cyt., 214-215.

86 R. Descartes, Lettre à Clerselier, w: Euvres de Descartes, dz. cyt., t. 4, 444. 
umysł zaś zaślepieniu, a wszyscy którzy przyzwyczajają się tak poruszać w ciemnościach, tak dalece osłabiają bystrość swych oczu, iż później nie mogą znieść pełnego światła"87. Jak zwracają uwagę historycy nauki, wypracowane przez Kartezjusza reguły teoriopoznawczo-metodologiczne są jednak ,tak ubogie, że śmiało możemy stwierdzić, iż wszystkie swe wspaniałe osiągnięcia zawdzięcza on pomysłom, których żadna z owych reguł dać nie mogła" 88 . Natomiast Błażej Pascal wydaje się być bliższy Arystotelesowi, który zakładając zdroworozsądkowo możliwość wartościowego poznania, skupiał się na wypracowaniu metody wykładu i uzasadnienia wiedzy zdobytej, traktując sylogistykę jako narzędzie swoiście pojętej dedukcji (dedukcja dydaktyczna ${ }^{89}$ ), stąd indukcję tylko wzmiankował w Analitykach ${ }^{90}$. W metodologicznym traktacie

87 R. Descartes, Prawidła kierowania umysłem, dz. cyt., 15-16; Tenże, Regulae ad directionem ingenii, dz. cyt., 371-372. Zob. L.J. Beck, The Method of Descartes. A Study of the Regulae, Oxford 1952, 172-189.

88 K. Scholz, Abriss der Geschichte der Logik, Freiburg 1959, 1967²; cyt. jako: Zarys historii logiki, tłum. z niem. M. Kurecka-Wirpszowa, Warszawa 1965, 26, przyp. 14. Przytacza się często parodię metody Kartezjusza sformułowaną przez Leibniza: „Przedsięweźmij to, co konieczne, czyń co powinieneś, a osiągniesz, co chciałeś”. Zob. L.J. Beck, The Method of Descartes, dz. cyt., 286. Na temat słabości metody Kartezjańskiej zob. J.A. Schuster, Cartesian Method as Mythic Speech. A Diachronic and Structural Analysis, w: The Politics and Rhetoric of Scientific Method. Historical Studies, red. J.A. Schuster, R.R. Yeo, Dordrecht 1986. Gwałtownym krytykiem lekceważenia przez Kartezjusza logiki formalnej był Józef M. Bocheński, który zarzucał mu, że miał o logice „ograniczone pojęcie”, choć był znakomitym matematykiem. Jednak ze względu na nośność zasad metodologicznych miał niekorzystnie zaważyć na dziejach logiki, co określi wręcz w kategoriach „,katastrofy”. Szczególnie piętnuje „,barbarzyńskie” potępienie formalizmu w logice. J.M. Bocheński, Spitzfindigkeit, w: Hommage aux catholiques suisses (Festgabe an die Schweizer Katholiken), Fribourg 1954, 334-352; toż jako: Subtelność, w: Tenże, Logika i filozofia. Wybór pism, tłum. z niem. D. Gabler, Warszawa 1993, 138.

89 Zob. S. Kamiński, Dedukcja w metafizyce scholastycznej, w: M.A. Krąpiec, S. Kamiński, Z teorii i metodologii metafizyki, Lublin 1962, 1994³, 346-344.

90 Standardom wiedzy naukowej odpowiadała jedynie Arystotelesowska filozofia przyrody, która zmierzała do odkrycia trwałej (koniecznej), istotnej i ogólnej rzeczywistości, ukrytej poza sferą dostępnych zmysłowo zjawisk, czyli formy substancjalnej oddającej naturę rzeczy ujawniającej się w działaniu. O ile punktem wyjścia tych analiz była indukcja, umożliwiająca na drodze uogólnień danych zmysłowych odkrycie form rzeczy ujętych w postaci definicji, to celem stworzenie wizji wyjaśniającej przez 
De l'esprit géométrique myśliciel z Port-Royal wyrażenie méthode odnosił przede wszystkim do procedury dowodzenia (démonstration), którą ponadto utożsamiał ze sztuką przekonywania (art de persuader) ${ }^{91}$. Twierdził bowiem, że kwestia sposobu wykrywania na drodze analizy prawd jeszcze nieznanych wydawała mu się już dostatecznie opracowana ${ }^{92}$, stąd też - jak słusznie zauważa Pierre Force - „Pascal generally uses the term metod ironically and pejoratively", jedynym wyjątkiem ma być wspomniane De l'esprit géométrique ${ }^{93}$. Celem jego zabiegów metodologicznych jest określenie sposobów udowodnienia prawd już znanych i odróżniania twierdzeń prawdziwych od fałszywych ${ }^{94}$. W precyzowaniu swej metody ograniczał się do analizy odkrytych już tez szeroko pojętej matematyki, w szczególności pytając, co uprawnia go

wykazanie, że są one racją (przyczyną) danych w doświadczeniu zjawisk, z których je można wydedukować. Zwieńczeniem procesu naukowego było hierarchiczne uporządkowanie rzeczywistości od najwyższych rodzajów do najniższych gatunków (systematyka). Ta kauzalistyczna wizja rzeczywistości oparta na empiryzmie genetycznym miała charakter systemu apodyktyczno-dedukcyjnego (założenia i twierdzenia udowodnione), którego forma zaczerpnięta była od matematyków starożytnych (zwłaszcza z Elementów Euklidesa). R.J. Hankinson, Science, w: The Cambridge Companion to Aristotle, red. J. Barnes, Cambridge 1995, 140-167; S. Kamiński, Koncepcja nauki u Arystotelesa, Zagadnienia Naukoznawstwa 16(1980), 11-17; toż w: Tenże, Metoda i język, Lublin 1994, 247-254); L. Nowak, Arystotelesowska teoria nauki, Studia Philosophiae Christianae 12(1976)1, 136-168; Z.E. Roskal, Astronomia matematyczna w nauce greckiej, Lublin 2002, 121-138.

91 B. Pascal, O geometrycznym sposobie myślenia, dz. cyt., 145-146; Tenże, De l'esprit géometrique, dz. cyt., 196.

92 Tenże, O geometrycznym sposobie myślenia, dz. cyt., 115-116; Tenże, De l'esprit géométrique, dz. cyt., 175-176.

93 P. Force, Pascal and Philosophica method, w: The Cambridge Companion to Pascal, Cambridge University Press: Cambridge 2003, 216.

94 „Roztrząsanie prawdy (étude de la vérité, dod. - SJ) może mieć trzy różne cele zasadnicze: po pierwsze - wykrycie prawdy, gdy jej szukamy; po wtóre - udowodnienie, gdy ją znamy, i na ostatek - odróżnienie od fałszu, gdy je badamy. Pierwszej kwestii nie omawiam; zajmuję się w szczególności drugą, ta zaś mieści w sobie i trzecią, jeśli kto bowiem zna metodę dowodzenia prawdy, zna tym samym metodę jej rozpoznawania”. B. Pascal, O geometrycznym sposobie myślenia, dz. cyt., 115; Tenże, De l'esprit géométrique, dz. cyt., 175. 
do przyjęcia określonych twierdzeń pierwotnych, bez formułowania ich dodatkowego uzasadnienia ${ }^{95}$.

Zasadniczo rzetelna metoda (cette véritable méthode) sformułowana przez Pascala daje się sprowadzić do skromnego, ale realistycznego postulatu dokładnego ustalenia znaczenia używanych terminów oraz posługiwania się tylko dowiedzionymi twierdzeniami ${ }^{96}$, czyli aksjomatami przyjętymi w sposób jasny i oczywisty, do przeprowadzania dowodu, zastępując terminy definicjami ${ }^{97}$. Ponieważ jednak w praktyce nie da się zdefiniować wszystkich pojęć i dowieść wszystkich zasad ze względu na niebezpieczeństwo popadnięcia w błędne koło przez odwoływanie się w definiowaniu terminów do innych terminów, które wcześniej trzeba byłoby zdefiniować, podobnie jak w przypadku twierdzeń, stąd „posuwając się coraz dalej musimy wreszcie dojść do terminów pierwotnych, których już nie możemy zdefiniować, oraz do zasad tak oczywistych, że nie można by znaleźć innych, jeszcze oczywistszych, mogących posłużyć do dowodzenia"98. Uprawnione jest więc odwołanie się do

95 W odróżnieniu od Kartezjusza, który uwzględniając współczesny sobie stan matematyki, postulował stworzenie matematyki odpowiadającej standardom określonej przez siebie metody matematycznej, Pascal widział urzeczywistnienie postulowanej przez siebie metody „geometrycznej” w kategoriach ówczesnej mechaniki, arytmetyki i geometrii, operując także szerszym rozumieniem geometrii, która obejmowałaby te dwie inne dziedziny matematyki, jednak akcentując modelowe znaczenie geometrii Euklidesa. B. Pascal, O geometrycznym sposobie myślenia, dz. cyt., 126; Tenże, De l'esprit géométrique, dz. cyt., 583. Por. Z. Drozdowicz, Kartezjusz a współczesność, Poznań 1980, 13-14.

96 B. Pascal, O geometrycznym sposobie myślenia, dz. cyt., 117; Tenże, De l'esprit géometrique, dz. cyt., 577.

97 „Sztuka, którą nazywam sztuką przekonywania, a która właściwie polega jedynie na przeprowadzaniu dowodów metodycznych i zupełnych, opiera się na trzech podstawach: na tym, by jasno zdefiniować terminy, którymi mamy się posługiwać, na tym, by podawać zasady czy aksjomaty, których prawdziwość jest oczywista, a które będą podstawą dowodzenia, oraz na tym, by podczas przeprowadzania dowodu stale podstawiać w myśli definicje w miejsce nazw". Pascal streszcza wszystkie wymogi swej metody matematycznej w Sztuce przekonywania, dz. cyt., 145; Tenże, De l'esprit géometrique, dz. cyt., 596. Szerzej zob. Tenże, Sztuka przekonywania, dz. cyt., 145-150; Tenże, De l'esprit géometrique, dz. cyt., 596-599.

98 Tenże, O geometrycznym sposobie myślenia, dz. cyt., 119; Tenże, De l'esprit géometrique, dz. cyt., 578-579. 
zasad, którymi posługuje się umysł ludzki, i to mocno ugruntowanymi w naturze ludzkiej. Dotyczy to przyjęcia bez definicji pewnych pojęć jasnych dzięki „światłu naturalnemu” (naturellement), np. przestrzeń, czas, ruch, liczba, równość oraz uznania pewnych jasnych powszechnie zasad, które mogą stanowić oparcie dla dowodów dalszych twierdzeń, dowodząc wszystkich innych. Wszystkie te wymagania urzeczywistnia geometria, której strukturę określił już Euklides; jest więc ona nauką modelową dla wszystkich innych nauk ${ }^{99}$. Nie można jednak zapominać, że Pascal realistycznie uważał, że realizacja powszechnego modelu uprawiania nauki more geometrico napotyka na istotne ograniczenia ${ }^{100}$, począwszy od konieczności pogodzenia się z faktem, że to tylko geometria ma być „niemal jedyną dziedziną nauki ludzkiej, która przytacza dowody niezbite... podczas gdy we wszystkich innych z przyrodzonej konieczności panuje jakiś zamęt, którego są w pełni świadomi tylko geometrzy"101.

Niemniej Pascal usiłuje szukać uniwersalnych podstaw ludzkiej wiedzy, wychodząc w pewnej mierze poza poznanie stricte racjonalne, postulując integralne wykorzystanie nie tylko rozumu i instynktu (instinct et raison), ale i rozumu, i doświadczenia (l'instinct et l'expérience ${ }^{102}$, co w drugim przypadku można odnieść tyleż do przyrodoznawstwa ${ }^{103}$, co

99 Tenże, O geometrycznym sposobie myślenia, dz. cyt., 116-121; Tenże, De l'esprit géométrique, dz. cyt., 576-579. W innym miejscu Pascal charakteryzuje geometrię jako naukę, która operuje tylko twierdzeniami „,całkowicie uzasadnionymi, albo dzięki światłu naturalnemu, albo też na mocy dowodów". Tenże, O geometrycznym sposobie myślenia, dz. cyt., 125; Tenże, De l'esprit géométrique, dz. cyt., 582.

${ }^{100}$ Zob. Z. Drozdowicz, Pascalowska koncepcja geometrycznego sposobu myślenia, w: Idee a rzeczywistość, red. S. Kaczmarek, Poznań 1980, 73-82.

${ }^{101}$ B. Pascal, O geometrycznym sposobie myślenia, dz. cyt., 117; Tenże, De l'esprit géométrique, dz. cyt., 576-577.

102 Tenże, Myśli, dz. cyt., 120; Tenże, Pensées, dz. cyt., 1158-1159.

${ }^{103}$ Metody stosowane w przyrodoznawstwie ujmował Pascal w kategoriach gry między doświadczeniem a rozumem. By odpowiednio planować eksperymenty, trzeba było bowiem kierować się określonymi ,,przypuszczeniami” (comment se fût-on imaginé), wykorzystywanymi - analogicznie, jak to dopuszczał Kartezjusz - nawet gdyby wydawały się one nieprawdopodobne w perspektywie dotychczasowych przekonań, tłumaczących błędnie określone zjawiska. Tenże, Fragment przedmowy do traktatu o próżni, w: Tenże, O geometrycznym sposobie myślenia, dz. cyt.; Tenże, Préface sur 
do historii, skoro podkreśli - niemal jak David Hume - rolę zwyczaju, działającego na zasadzie automatu: ,,Jak mało jest rzeczy dowiedzionych! Dowody przekonywają jedynie rozum; najsilniejsze i najskuteczniejsze dowody tworzy zwyczaj; on urabia automat, który pociąga za sobą ducha bez jego wiedzy. Kto wykazał, że jutro będzie dzień i że pomrzemy?"'104. Jednocześnie jednak - tym razem jak Thomas Reid, przezwyciężający Hume'owski sceptycyzm - wskaże uniwersalistycznie: „Umysł posiada prawdy przyrodzone i powszechnie znane, tak jak na przykład, że całość jest większa od części, prócz tego zaś - wiele szczególniejszych aksjomatów, które jedni przyjmują, a inni odrzucają, które jednakże, gdy zostaną uznane, to - choćby były fałszywe - mają tę samą moc przekonywania, co nieprawdziwe"105. Naturalnie przekonanie o tak szerokim „,naturalnym” wyposażeniu ludzkiego umysłu na wzór filozofii szkockiej można podważyć argumentem, że Pascal wypowiadał się nie jako filozof nauki, ale jako teoretyk retoryki, tezę tę formułuje bowiem w tekście $O$ sztuce przekonywania. Wątek ten jest na tyle istotny w metodologii Pascala, że niektórzy widzą w zaprezentowanej metodzie tylko sposób przekonywania do prawdy, a nie dochodzenia do prawdy, charakterystyczny dla Kartezjusza ${ }^{106}$; jednakże Pascal dostrzegał znaczenie także przedmiotowego, a więc filozoficznego charakteru tych tez, gdyż retoryczna argumentacja jest ugruntowana faktycznym stanem rzeczy, do którego się odnosi (realizm) ${ }^{107}$.

Nawet jednak w tym przypadku trudno dopatrywać się niekrytycznego optymizmu poznawczego. Pascal dostrzega bowiem, że

le Traité du vide, w: Euvres complètes, dz. cyt., 529-535. Por. S. Janeczek, Logika czy epistemologia?, dz. cyt., 246-255, 267-268.

${ }^{104}$ B. Pascal, Myśli, dz. cyt., 203; Tenże, Pensées, w: Tenże, CEuvres complètes, dz. cyt., 1219.

105 Tenże, O geometrycznym sposobie myślenia, dz. cyt., 142; Tenże, De l'esprit géometrique, dz. cyt., 593.

106 S. Rohmanowa, Wstęp, w: A. Arnauld, P. Nicole, Logika, czyli sztuka myślenia, tłum. z franc. S. Rohmanowa, Warszawa 1958, XV.

107 „Sztuka przekonywania jest zależna z jednej strony od tego, w jaki sposób ludzie uznają za słuszne to, co mówimy, z drugiej zaś strony - od stanu rzeczy, o których mówimy". B. Pascal, O geometrycznym sposobie myślenia, dz. cyt.,140; Tenże, De l'esprit géométrique, dz. cyt., 592. 
instynktownie przyjęte prawdy (bez dowodu) mogą być błędne, podobnie jak błędny może być zwyczaj. Naczelny wymóg dowodzenia uznanych prawd, na ile i kiedy to jest możliwe, odpowiada postulatowi Reida dotyczącego weryfikacji tez uznawanych za prawdy powszechne, skoro w przeszłości przyjmowano ich ponad miarę, nie unikając niebezpieczeństwa popadnięcia w przesądy ${ }^{108}$. Równocześnie Pascal jest przeciwny - charakterystycznemu dla Kartezjusza - rygorystycznemu wymogowi przyjmowania prawd tylko na zasadzie oczywistości podmiotowej, godząc się na skromniejszy postulat ,uznawania za prawdę tylko tego, czego przeciwieństwo uzna za fałsz"109.

Wsparciem interpretacji o uniwersalnym charakterze pierwotnych prawd dostępnych człowiekowi dzięki ,światłu naturalnemu" (naturellement) mogą być rozważania Pascala dotyczące pytania o zakres stosowania metody matematycznej, gdy wybitny matematyk paradoksalnie przeciwstawi sobie kulturę matematyczną (esprit de géométrie) tzw. przyrodzonej bystrości (esprit de finesse) czy esprit fin, a więc skłonności do teleologicznego postrzegania struktury rzeczywistości. Wypracowuje bowiem zasady kultury logicznej w formie tzw. prawego zmysłu (sens droit), utożsamianego z l'esprit de justesse ${ }^{110}$. To szeroko

${ }^{108}$ Th. Reid, Rozważania o władzach poznawczych człowieka, dz. cyt., 636-639.

${ }^{109}$ B. Pascal, O geometrycznym sposobie myślenia, dz. cyt., 130; Tenże, De l'esprit géometrique, dz. cyt., 585.

${ }^{110}$ Witold Marciszewski wskazując na trudności z oddaniem specyfiki treściowej finesse, jak i sens droit, w języku angielskim tłumaczonych w pierwszym przypadku np. jako intuitive mind, a w drugim jako penetraitive intellect, postuluje wyrazić je przez łacińskie określenie acumen, by zgodnie z intencjami Pascala objąć zarówno szybkość działań umysłu, jak i ich jednoczesną głębię, tak na poziomie tworzenia pojęć, jak i rozumowania. W. Marciszewski, Logic from a Rhetorical Point of View, Berlin 1994, 10-12. Na marginesie, kategorią tą operował Maciej K. Sarbiewski, teoretyk manieryzmu, podkreślając rolę wyszukiwania błyskotliwych konceptów, które jako „zgodna niezgodność lub niezgodna zgodność” (,Acumen est concors discordia et discors concordia") miały zaskakiwać słuchaczy, wywoływać zdumienie oraz podziw i w ten sposób sprawiać przyjemność M.K. Sarbiewski, Wykłady z poetyki (Praecepta poetica), tłum. z łac. S. Skimina, Wrocław 1958, 10. Traktat De acuto et arguto, pochodzący z wykładów z lat 1619/20, nie tylko wywołał dyskusję, w której uczestniczyli najwybitniejsi ówcześni teoretycy wymowy, ale i wyprzedzał o 20 lat dokonania hiszpańskich i włoskich twórców manieryzmu. Zob. P. Lewin, Teoria 
pojęte usprawnienie logiczne, określane jako trudna do przełożenia naturalna subtelność i związana z tym wrażliwość, różni się jednak od sprawności właściwej rozumowaniom matematyków, także na gruncie matematyki stosowanej (np. hydrologia czy hydrografia). Ta ostatnia jest przecież nie tylko efektem prostego wyposażenia naturalnego, gdyż nabywamy ją z wysiłkiem zapewniającym trwałą sprawność (habitude), stąd jest odległa od potocznego myślenia (usage commun). Nabycie tych usprawnień ma uniemożliwić popełnienie błędów, zasady bowiem, zapewne w sensie aksjomatów, którymi operuje matematyka, mają być tak ,grube” (gros), że prawie niepodobna ich przeoczyć ${ }^{111}$.

Inaczej jest z przyrodzoną bystrością, która ma charakter potoczny, nie wymaga więc kształcenia, lecz występuje faktycznie w sposób ustopniowany, co dostrzegał także Kartezjusz, jak wspomniano wyżej. Usposobienie to uwarunkowane jest w dwu aspektach, bo z jednej strony ma umożliwiać jasne widzenie wszystkich zasad (,la vue bein nette pour voir tous les principes"), które są nieporównanie liczniejsze od tych, którymi faktycznie operuje matematyka. Z drugiej strony obejmuje sprawności formalne (esprit juste), by nie rozumować fałszywie na podstawie uznanych zasad. W praktyce jednak przedmioty dostępne temu przyrodzonemu usprawnieniu widzimy tylko z trudnością, a nawet je raczej tylko odczuwamy (sentir), stąd nie są one tyle przedmiotem właściwego dowodzenia (démontrer), co słusznego osądu (juger droit) i odczuwania (juste sentiment). Ich udowodnienie według metod matematyki nie jest możliwe zarówno ze względu na niemożność ścisłego ujęcia szeroko pojętych zasad (principes) - czyli zapewne rozmaicie pojętych materialnych przesłanek myślenia - jak i ze względu na ich wielką liczbę, wykluczającą praktycznie możliwość ich udowodnienia, ze względu na niebezpieczeństwo błędu dowodzenie bez końca. Stąd też-należy przypuszczać - zapewne w innych, a przy tym liczniejszych niż matematyka dziedzinach poznania, w miejsce procedur charakterystycznych dla metody matematycznej - a więc w sposób różny od

akuminu w estetycznej świadomości wschodniej słowiańszczyzny XVII-XVIII wieku a traktat Sarbiewskiego, w: Literatura staropolska i jej związi europejskie, red. J. Pelc, Wrocław 1973, 309-322.

111 B. Pascal, Myśli, dz. cyt., 30; Tenże, Pensées, dz. cyt., 1091-1092. 
tego, co sugerowała rozprawa dotycząca metody geometrycznej, która zalecała operowanie ściśle określonymi definicjami i zasadami - Pascal postuluje operowanie metodą intuicyjną. Ujmuje ją w kategoriach umiejętności ogarniania rzeczy od razu, ,jednym rzutem” (voir d'une vue), a nie na drodze kolejnych rozumowań, przynajmniej na pewnym etapie ujęcia tych spraw. Dotyczy ona praktyki życiowej, np. w odniesieniu do ujmowania uczuć. Nic więc dziwnego, że także w Pensées Pascala śmieszą usiłowania generalizacji metody matematycznej ${ }^{112}$.

Pascalowski sens droit, określany też jako esprit de justesse, jest jednocześnie prosty, co i prawy oraz ścisły i trafny, czym różni się od umysłu opacznego (esprit faux). Może być on uznany za szeroko pojętą władzę logicznego myślenia, a więc równocześnie opartą tak na wyposażeniu naturalnym, jak i faktycznie to wyposażenie urzeczywistniającą, choć różną od usprawnienia specjalistycznego, jakim jest kultura matematyczna. Na marginesie tych uwag widać, że Pascal w sposób daleki od zawodowego epistemologa swobodnie zastępuje terminy sens czy esprit, a więc ,zmysł” czy „umysł”, jak też termin sentir, który może być tak synonimem uczuć, jak i intuicji intelektualnej, przypominającej intuicję Kartezjańską. Nic więc dziwnego, że powiąże sąd (le jugement) - będący już dla Kartezjusza przede wszystkim aktem woli w odróżnieniu od operacji percepcji - tak z czuciem czy uczuciem (le sentiment), jak i z ową przyrodzoną bystrością (la finesse), którym przeciwstawi systematycznie pojętą naukę, jako rzecz umysłu (le esprit), artykułującą i - pewnie - petryfikującą swe reguły; pojętą na dodatek już nie tylko w sensie matematyki, przeciwstawianej wcześniej kulturze logicznej, ale także regułom wymowy czy moralności, różnym od praktycznych usprawnień w tych dziedzinach ${ }^{113}$.

W tym kontekście nie sposób nie dostrzec innego wykroczenia poza matematyczną kulturę dowodzenia, jakim jest swoista „logika serca”114.

112 Tenże, Myśli, dz. cyt., 30-32; Tenże, Pensées, dz. cyt., 1092-1093.

113 Tenże, Myśli, dz. cyt., 32-34; Tenże, Pensées, dz. cyt., 1093-1095.

114 Zob. T. Płużański, Pascal, Warszawa 1974, 44-64; J. Laporte, La Cour et la raison selon Pascal, Reveue philosophique de la France et de l'Etranger 103(1927), 98-118, 225-299, 421-451; toż jako druk samoistny: Paris 1950. Por. L. Goldmann, Le Dieu caché, Paris 1955; Z. Drozdowicz, Antynomie Pascala, Poznań 1993; Odczytywanie myśli Pascala, red. A. Siemianowski, Wydawnictwo Fundacji Humaniora, Poznań 
Wątek ten podejmuje Pascal już w O sztuce przekonywania. Wymagał w niej zarówno stosowania sztuki argumentowania (convaincre), jak i sztuki zjednywania serc (agréer), a więc nakazując uwzględnienie znajomości struktury psychicznej interlokutora, gdy odwołuje się do jego woli ${ }^{115}$. Nic dziwnego, że Pascal podtrzymuje woluntarystycznie pojętą koncepcję sądu, sformułowaną przez Kartezjusza, i za nim w aktach woli widzi źródło błędów, gdy „odwraca rozum od właściwości, które nie rada jest oglądać"116.

Przede wszystkim to w Myślach Pascal przeciwstawia ,porządkowi rozumu” (raison) ,porządek serca” (coeeur), nadto to temu drugiemu wyznacza priorytet przynajmniej w odniesieniu do poznania pierwszych zasad (premiers principes), niedostępnych rozumowi (,serce ma swoje racje, których rozum nie zna"), choćby nielicznych, np. wspomnianych w rozprawie o metodzie matematycznej takich, jak przestrzeń, czas, ruch czy liczby. Ta obrazowo określana wiedza serca - zapewne o charakterze intuicyjnym, choć Pascal nie używa tego filozoficznego terminu - jest tożsama z porządkiem czucia czy uczucia, nawet z instynktem $^{117}$. Co więcej, to ona, a nie rozum, jest podstawą przezwyciężenia wszelkich odmian sceptycyzmu, a właściwe także równie nieuprawnionego dogmatyzmu, przy czym jedno i drugie jest wynikiem dramatycznie postrzeganych ograniczeń poznawczych, ujawniających

1997; B. Norman, Portraits of Thought, Knowledge, Methods and Styles in Pascal, Columbus 1988; H.M. Davidson, The Origins of Certainty. Means and Meanings in Pascal's Pensées, Chicago 1979; Méthodes chez Pascal. Actes du colloque tenu à Clermont-Ferrand 10-13 juin 1976, red. J. Mesnard, Paris 1979; T.M. Harrington, Vérité et méthode dans les Pensées de Pascal, Paris 1972.

115 B. Pascal, O geometrycznym sposobie myślenia, dz. cyt., 143-144; Tenże, De l'esprit géometrique, dz. cyt., 594. Przykładem traktowania sztuki przekonywania jako retoryki jest wskazanie, iż w przypadku aksjomatów, które nie należą do kręgu pierwotnych, z których jedne są przez jednych przyjmowane, a przez innych nie, w przypadku ,gdy zostaną uznane, to - choćby były fałszywe - to wówczas mają one tę samą moc przekonywania, co najprawdziwsze". B. Pascal, O geometrycznym sposobie myślenia, dz. cyt., 142; Tenże, De l'esprit géometrique, dz. cyt., 593.

${ }^{116}$ B. Pascal, Myśli, dz. cyt., 204; Tenże, Pensées, dz. cyt., 1220. Zob. S. Lubańska, Sceptycyzm Pascala, Filo-Sofia 7(2012)2, 75-82.

117 B. Pascal, Myśli, dz. cyt., 44, 201-207; Tenże, Pensées, dz. cyt., 1102, 1218-1222. 
się na wszelkich poziomach wiedzy naturalnej ${ }^{118}$. Źródłem ograniczeń szeroko pojętego poznania ma być - w sposób typowy dla jansenistycznego stylu rozważań Pascala - skażenie ludzkiej natury, a co za tym idzie i skażenie rozumu, określane jako la corruption de la raison, a więc - znów nieprzypadkowo - pojętego jako władza dyskursywna, charakterystyczna dla nowożytnego racjonalizmu ${ }^{119}$. Jeśli więc Pascal wzywa do „zaparcia się rozumu” (désaveu de la raison), nawet jeśli ma być to paradoksalnie „zgodne z rozumem”, to jest to w istocie przejaw zdroworozsądkowego postulatu przestrzegania porządków właściwych różnym rodzajom poznania, obejmującego świadomość swych ograniczeń poznawczych ${ }^{120}$. Nic więc dziwnego, że to właśnie w integralnie pojętej władzy poznawczej - określanej najogólniej jako tytułowa la pensée, myśl ${ }^{121}$, jako wyraz tyleż ludzkiego umysłu, co

118 Zarówno w Myślach, jak i zwłaszcza w Rozmowie z panem de Saci (B. Pascal, w: Rozprawy i listy, dz. cyt., 67-102; Tenże, Euvres complètes, dz. cyt., 560-574), gdzie pozostaje pod niewątpliwym wpływem M. Montaigne, Pascal dostrzega wielość ograniczeń poznawczych (błędy i niepełność) ujawniających się począwszy od zmysłów przez wyobraźnię i zwyczaje aż po poznanie racjonalne, tak w zakresie problematyki filozoficznej - wskazując na niesprowadzalność rozwiązań formułowanych przez jej tradycję, np. w zakresie rozumienia cnoty czy substancji - jak nauk przyrodniczych, a nawet matematyki. W tym ostatnim przypadku - obok trudności ze zrozumieniem pojęcia nieskończoności, którym operowały modne wówczas działy matematyki-zauważa także, iż nie ma gwarancji, że twierdzenia, które przyjmuje się jako ostateczne, mogą zakładać jeszcze bardziej pierwotne, co wydaje się - na ile pozwala interpretacja tego enigmatycznego sformułowania - naruszać prawdę o intuicyjnym ujęciu pierwszych prawd, które Pascal uznawał przecież za niepowątpiewalne. B. Pascal, Myśli, dz. cyt., 49-93; Tenże, Euvres complètes, dz. cyt., 1103-1137.

119 Tenże, Myśli, dz. cyt., 179; Tenże, Pensées, dz. cyt., 1202.

120 „Trzeba umieć wątpić, tam gdzie trzeba, twierdzić, tam gdzie trzeba, i poddać się tam gdzie trzeba. Kto czyni inaczej, nie pojmie siły rozumu". Uwidaczniający się w tym aforyzmie racjonalizm metodologiczny ujawni się w krytycznej ocenie, jaką rozum ma odnosić także do swych możliwości poznawczych, w czym podąża Pascal za opinią św. Augustyna (Epist. 110): „Rozum nie poddałby się nigdy, gdyby nie uznał, że istnieją okoliczności, w których należy się poddać”. Tenże, Myśli, dz. cyt., 201-202; Tenże, Pensées, dz. cyt., 1218.

${ }^{121}$ Kategoria szeroko pojętego myślenia ujawnia się w tytule bardzo popularnego, bo zachowującego dorobek tradycji i ostrożnie asymilującego osiągnięcia nowożytności podręcznika logiki, korzystającego nieprzypadkowo z osiągnięć epistemologicznych Pascala, jakim jest Antoine Arnaulda i Pierre Nicole La logique, ou l'art de penser 
i ludzkiego ducha (la esprit), różnego od prostego instynktu zwierzęcego $^{122}$, pozwalającej dostrzec ludzką nędzę (la misère), ujawniającą się nie tylko w wymiarze poznawczym - widzi źródło godności (la dignité) człowieka ${ }^{123}$. Pascal domaga się splotu wszystkich usprawnień poznawczych, odpowiednio do ich właściwości, zwłaszcza w zakresie sposobu akceptacji twierdzeń: „I na tych wiadomościach serca [le cœur, dod. - SJ] i instynktu [le instinct, dod. - SJ] musi się opierać rozum [la raison, dod. - SJ] i na nich budować wszystkie swoje wywody. Serce czuje [sentir, dod. - SJ], że są trzy wymiary przestrzeni i że liczby są nieskończone; rozum dowodzi następnie, że nie ma dwóch kwadratów liczb, z których jeden byłby podwójną drugiego. Zasady czujemy, twierdzenia wyprowadzamy za pomocą dowodu; i jedno, i drugie pewnie, mimo że odmiennymi drogami. I równie bezcelowe i niedorzeczne jest, aby rozum żądał od serca udowodnienia pierwszych zasad, nim zgodzi się na nie przystać, jak byłoby niedorzeczne, aby serce - nim zgodzi się je przyjąć - żądało od rozumu czucia wszystkich twierdzeń, które ten udowadnia"124. Świadomy uniwersalistycznych żądań rozumu doby nowożytnej, Pascal podkreśli nawet wagę instynktu i szeroko pojętego czucia czy uczucia, choć zaznacza, że zakres tych ostatnich prawd jest wielce ograniczony. Wbrew roszczeniom rozumu stwierdzi: „Dałby Bóg, abyśmy go, przeciwnie, nigdy nie potrzebowali i abyśmy znali wszystkie rzeczy instynktem i czuciem [le sentiment, dod. - SJ]! Ale natura odmówiła nam tego dobra; dała nam, przeciwnie, bardzo

contenant, outre les règles communes, plusieurs observations nouvelle propres à former le jugement, par le Sieur le Bon (Paris 1662; przedr. wydania z roku 1638 Hildesheim 1970; toż jako: Logika, czyli sztuka myślenia, tłum. z franc. S. Rohmanowa, Warszawa 1958). Poszerza ona przedmiot tradycyjnej logiki, przekształcając tradycyjną ars ratiocinandi w szerzej pojętą ars cogitandi, czyli sztukę myślenia. Stąd też nieprzypadkowo dołącza do trzech traktatów o pojęciu, sądzie i rozumowaniu, wątek poświęcony metodzie. Zob. S. Janeczek, Logika czy epistemologia?, dz. cyt., 279-306.

122 B. Pascal, Myśli, dz. cyt., 117; Tenże, Pensées, dz. cyt., 1156.

123 Tenże, Myśli, dz. cyt., 116-120; Tenże, Pensées, dz. cyt., 1156-1158.

${ }^{124}$ Tenże, Myśli, dz. cyt., 206; Tenże, Pensées, dz. cyt., 1222. 
niewiele wiadomości tego rodzaju; wszystkie inne możemy nabyć jedynie rozumowaniem" 125 .

Tezy o jedności ludzkiej wiedzy nie narusza też fakt, że sugestywna krytyka wąsko pojętego racjonalizmu jest formułowana przez Pascala przede wszystkim w perspektywie charakterystycznych dla nowożytności prób jego sekularyzacji, przeciwstawiania rozumu wierze religijnej, przy czym relacja ta ma charakter (pod)przeciwieństwa a nie sprzeczności, bo zakłada ograniczoną koegzystencję (dopełnianie, a nie wykluczanie) fides i ratio, wyrażoną w formule: „Poddanie i użycie rozumu - oto na czym polega chrystianizm"126. Choć bowiem Pascal uzna wiarę za akt Bożej łaski (un don de Dieu $)^{127}$, to przecież nie wyklucza to możliwości swoistego, racjonalnego podprowadzenia do aktu wiary ${ }^{128}$, co jest podstawowym zadaniem jego apologetycznie nastawionej filozofii religii. Uzna on nawet, że argumenty przemawiające za religią zapewniają jej tak ceniony w nowożytności wymóg oczywistości ${ }^{129}$. Stąd też realistycznie, wśród trzech dróg do wiary - obok natchnienia (inspiration, a właściwie révélation) - wymieni rozum i zwyczaj (coutume). Co więcej, choć naturalnie podkreśli rolę pierwszego czynnika, to przecież stwierdzi równie kategorycznie: „Nie znaczy to, aby [wiara, dod. -SJ] wykluczała rozum i zwyczaj - przeciwnie; ale trzeba otwo-

${ }^{125}$ Tenże, Myśli, dz. cyt., 206; Tenże, Pensées, dz. cyt., 1222.

${ }^{126}$ Tenże, Myśli, dz. cyt., 202; Tenże, Pensées, dz. cyt., 1218.

127 „Wiara - to dar Boga; nie sądźcie, bym twierdził, że to jest dar rozumowania”. Tenże, Myśli, dz. cyt., 207; Tenże, Pensées, dz. cyt., 1222.

128 „I oto czemu ci, którym Bóg dał religię z poczucia serca, bardzo są szczęśliwi i bardzo słusznie przekonani. Ale tym, którzy jej nie mają, możemy ją dać jedynie rozumowaniem w oczekiwaniu, aż Bóg da im ją przez poczucie serca, bez czego wiara jest jeno ludzka i bezużyteczna dla zbawienia”. Tenże, Myśli, dz. cyt., 207; Tenże, Pensées, dz. cyt., 1222.

${ }^{129}$ „Nie żądam, abyś mi podał swą wiarę bez racji, i nie mam zamiaru ujarzmić cię tyrańsko. Nie zamierzam również zdać ci sprawy ze wszystkich rzeczy; aby pogodzić te sprzeczności, mam zamiar ukazać ci jasno, za pomocą nieodpartych dowodów, boskie oznaki we mnie, które by cię przekonały, czym jestem i zyskałyby mi powagę za pomocą cudów i dowodów niepodobnych do odtrącenia; abyś następnie wierzył w rzeczy, których cię nauczam, skoro nie znajdziesz żadnej przyczyny do odrzucenia ich, chyba tę że nie możesz sam przez siebie poznać, czy one istnieją, czy nie". Tenże, Myśli, dz. cyt., 212; Tenże, Pensées, dz. cyt., 1227. 
rzyć swój umysł na dowody, umocnić go przez zwyczaj"' ${ }^{130}$. Nie można jednak zapominać, że ograniczone przeciwstawienie religii i rozumu wynika przede wszystkim z pierwotniejszego rozstrzygnięcia epistemologicznego jakim było dla Pascala przeciwstawienie porządku rozumu i serca. Dla Pascala bowiem religia jest sprawą nie rozumu, ale serca ${ }^{131}$. $\mathrm{W}$ tym to kontekście zrozumiała jest - z powołaniem się na Biblię idea Boga ukrytego dla rozumu (Iz 45, 15), z którą powiązana jest idea soteriologicznie pojętego zasługiwania, niemożliwego, zdaniem Pascala, gdyby wiara jawiła się w sposób jasny rozumowi ${ }^{132}$. Ten porządek ponadracjonalny - co do treści wiary - nie może być więc przedmiotem filozofii. Nie można bowiem nie dostrzec, że Pascal niemal obok siebie zestawia w Myślach triady: „serce, instynkt, zasady” (cour, instinct, principes) ${ }^{133}$ oraz: „rozum, zwyczaj, natchnienie” (la raison, la coutume, l'inspiration $)^{134}$, w sensie objawienia, co nakazuje traktować wiarę jako „dar Boga”. Jeśli zaś „Boga czuje serce, nie rozum. (...) Bóg dotykany dla serca, nie dla rozumu"'135, to także tę tezę należy traktować jako kolejny wyraz podkreślenia roli intuicji, na co wskazuje triada „serce, instynkt, zasady". Bowiem to na gruncie tego typu poznania ujmujemy to, co w rzeczywistości jest fundamentalne, a więc i Boga, choć nie możemy poznać jego istoty, która jest przedmiotem wiary religijnej.

Czy więc należy uznać epistemologię Pascala za przejaw fideizmu? Ponadnaturalnie pojęta religia nie tyle sprzeciwia się zmysłom czy rozumowi, co je przewyższa ${ }^{136}$. Stąd też Pascal bagatelizuje próby racjonalizacji religii w tym sensie, jakby rozum mógł udowodnić jej prawdy. Wiara nie jest bowiem pewna w kategoriach pewności charakterystycznej dla poznania racjonalnego, zresztą i ono jest przecież

${ }^{130}$ Tenże, Myśli, dz. cyt., 207; Tenże, Pensées, dz. cyt., 1223.

131 „Boga czuje serce, nie rozum. Oto co jest wiara: Bóg dotykalny dla serca, nie dla rozumu". Tenże, Myśli, dz. cyt., 207; Tenże, Pensées, dz. cyt., 1222.

${ }^{132}$ Tenże, Myśli, dz. cyt., 278-280; Tenże, Pensées, dz. cyt., 1276.

133 Tenże, Myśli, dz. cyt., 205; Tenże, Pensées, dz. cyt., 1221.

134 Tenże, Myśli, dz. cyt., 207; Tenże, Pensées, dz. cyt., 1223.

135 Tenże, Myśli, dz. cyt., 207; Tenże, Pensées, dz. cyt., 1222.

136 „Wiara powiada wprawdzie to czego nie mówią zmysły, ale nie mówi rzeczy przeciwnych temu, co one widzą. Stoi ponad nimi (au-dessus), ale nie wspak im (non pas contre)". Tenże, Myśli, dz. cyt., 201; Tenże, Pensées, dz. cyt., 1218. 
niepewne, bo zakłada np. stałość porządku przyrody, o którym wyrokujemy, przewidując przyszłe zdarzenia, stąd paradoksalnie wiara jest nawet pewniejsza niż twierdzenia racjonalne ${ }^{137}$. Czyż nie inaczej twierdził jednak Locke, traktując - analogicznie zresztą jak św. Tomasz z Akwinu - jako specyficzne dla religii prawdy określane jako supra rationem, przecież z nim niesprzeczne, a widzi się w nim nawet ojca racjonalizmu religijnego ${ }^{138}$.

Wydaje się w końcu, że dla Pascala - jak dla Reida - pozadowodliwe założenia „wcale nie znamionują niedoskonałości i niepewności naszej wiedzy. To jest bowiem niepewne, co potrzebuje dowodu, a to, co jest jego podstawą, choć niedowodliwe, może być bardziej pewne niż to, co jest dowodzone", jak słusznie stwierdza Piotr Gutowski ${ }^{139}$. To prawda, Reid i Pascal przyjmują tezy niedowodliwe, ale przecież równocześnie dla rozumu oczywiste, jednak nie w dyskursie, ale na drodze intuicyjnej czy instynktownej. Czym innym jest więc kwestia przyjęcia jako niedowodliwego punktu wyjścia filozofowania, zwłaszcza że są to przecież pierwsze zasady, a czym innym niejasna kwestia sposobu ich odkrywania.

Istotnym argumentem za uznaniem myśli Pascala za przejaw sygnalizowanego wyżej ,agnostycyzmu w obrębie teizmu” jest brak systemowej wykładni metafizyki. Choć Reid budował nawet metafizykę, choćby głównie w zakresie jej odniesień światopoglądowych ${ }^{140}$, to przecież

137 Tenże, Myśli, dz. cyt., 199; Tenże, Pensées, dz. cyt., 1216; por. Tenże, Myśli, dz. cyt., 72; Tenże, Pensées, dz. cyt., 1121. Jest to ważny motyw, który stanie się trwałym elementem nowożytnej metodologii nauk przyrodniczych, które będą usiłowały przybrać kształt systemu analogicznego do koniecznościowego charakteru tez tradycyjnej filozofii, mimo często hipotecznego charakteru praw nauki, przy czym jeszcze w charakterystycznym dla wieku XVIII podbudowaniu fizyki metafizyką, gwarancję trwałości praw przyrody powszechnie widzi się w odwiecznych decyzjach Boga-Stwórcy. J.R. Milton, Laws of Nature, w: The Cambridge History of Seventeenth-Century Philosophy, t. 1, red. D. Garber, M. Ayers, Cambridge 1998, 686-687.

${ }_{138}$ Zob. S. Janeczek, Logika czy epistemologia?, dz. cyt., 422-434.

139 P. Gutowski, O trzech elementach filozofii Thomasa Reida, dz. cyt., 89. Por. M. Hempoliński, Uźródel filozofii zdrowego rozsądku. Thomasa Reida teoria spostrzeżenia zmysłowego, Warszawa 1966, 376.

${ }^{140}$ Tendencja do ograniczenia roli metafizyki ogólnej, przy równoczesnym rozbudowaniu metafizyk szczegółowych, jest charakterystyczna dla oświeceniowej praktyki 
wątków tych nie ujął w formie odrębnych publikacji, ograniczając się do druku dzieł z zakresu epistemologii i etyki. Autor opracowania dotyczącego jego filozofii religii tłumaczy to m.in. brakiem oryginalności filozofii Boga wzorowanej na Clarke'u. Przede wszystkim wskazuje jednak, że Reid był przekonany, że najważniejsza w ówczesnej kulturze filozoficznej jest epistemologia, stąd jej błędne rozstrzygnięcia są największym zagrożeniem dla teizmu ${ }^{141}$. Reid postępował w tym względzie za Lockiem ${ }^{142}$, dzieląc także jego zdroworozsądkowy umiar ${ }^{143}$, choć bo-

dydaktycznej. Zob. S. Janeczek, Koncepcja ,filozofii chrześcijańskiej” w pismach polskich pijarów w okresie oświecenia. Uwagi metodologiczno-historyczne, Roczniki Filozoficzne 41(1993)1, 125-155.

${ }^{141}$ D. Tuggy, Reid's Philosophy of Religion, dz. cyt., 290.

${ }^{142}$ Nie wolno zapominać, że mimo iż Locke funkcjonuje w dziejach filozofii przede wszystkim jako oryginalny i wpływowy epistemolog, to rodowód traktatów z tej dziedziny jest w pewnej mierze dość „,przypadkowy”. Były one bowiem w istocie swoistą wprawką w podejmowaniu tematów „bardzo odległych” od występujących w An Essay Concerning Human Understanding, co sygnalizuje w przedmowie do Rozważań sam ich autor. Stwierdza, że do zainteresowania się tą tematyką skłoniły go rozmowy w kręgu przyjaciół, w trakcie których dla sprecyzowania stanowisk konieczne okazało się rozstrzygnięcie kwestii epistemologicznych, przede wszystkim oceniając, „,z jakimi przedmiotami nasze zdolności poznawcze mogą sobie poradzić”. J. Locke, An Essay Concerning Human Understanding, London 1690, właściwie 1689; cytowane w ramach wydania The Works of John Locke, London 18233; repr. Aalen 1963, t. 1, XLVI-XLVII; toż jako Rozważania dotyczace rozumu ludzkiego, tłum. z ang. B. Gawecki, Warszawa 1955, t. 1, 9-10. O „przypadkowości” (chance) tego zamierzenia świadczy także uwaga, że problematyką tą nigdy wcześniej się nie zajmował, a samo dzieło powstawało powoli, spisywane urywkami i z przerwami, gdy sprzyjały temu usposobienie i okoliczności, stąd uporządkował je ostatecznie, gdy ,znalazł się w zaciszu”. Zob. R. Brandt, John Locke, w: Die Philosophie des 17. Jahrhunderts, t. 3. red. J.-P. Schobinger, Basel 1988, 624, 626; M. Cranston, John Locke. A Biography, London 1957, 140-141. Por. S. Janeczek, Racjonalizm kultury intelektualnej Johna Locke'a. Roczniki Kulturoznawcze 2(2011), 51-70.

${ }^{143}$ Locke, broniąc realizmu poznawczego, stwierdzał, że wiedza dotycząca idei jest zgodna z rzeczywistością i to w sposób odpowiadający wiedzy pewnej, czyli knowledge („Gdziekolwiek postrzegamy zgodność lub niezgodność jakichkolwiek naszych idei, tam mamy wiedzę pewną; a kiedykolwiek jesteśmy pewni, że idee te są zgodne z realnością rzeczy, mamy wiedzę pewną i realną". J. Locke, Rozważania dotyczace rozumu ludzkiego, dz. cyt., t. 2, 397; Tenże, An Essay Concerning Human Understanding, dz. cyt., t. 3, 1-7. Por. uwagi Locke'a dotyczące pewności w zakresie 
wiem metafizyka nie mieściła się w fenomenalistycznie ukierunkowanej epistemologii myśliciela brytyjskiego, to przecież - choćby niekonsekwentnie - posługiwał się on kategorią substancji ${ }^{144}$, co umożliwiało

wiedzy o istnieniu rzeczywistości pozapodmiotowej, które sformułował w dyskusji z Edwardem Stillingfleetem, choć dalej bronił koncepcji nauki, której przedmiotu upatrywał w badaniu tylko stosunków między ideami - An Essay Concerning Human Understanding, dz. cyt., t. 6, 360), Podejście takie prowadziło do nobilitacji wiedzy empirycznej, w zgodzie zresztą z empiryzmem Locke'a w zakresie genezy idei (kauzalizm). Miało owocować ono przezwyciężeniem płaskiego reprezentacjonizmu zakładającego ,prymitywny dualizm” idei i rzeczy, w konsekwencji-ugruntowaniem realizmu, skoro można ujmować zgodność idei i rzeczy (a nie tylko zgodność zachodzącą między ideami), a ostatecznie odparciem sceptycyzmu, jednak chyba właśnie na gruncie pewnej formy filozofii zdrowego rozsądku, zapowiadającej rozwiązania T. Reida. Do tej opcji Locke odwoływał się zresztą wprost w obronie zasady niesprzeczności. J. Locke, Rozważania dotyczace rozumu ludzkiego, dz. cyt., t. 1, 62; t. 2, 322; Tenże, An Essay Concerning Human Understanding, dz. cyt., t. 1, 37; t. 3, 43. Zob. A.D. Woozley, Some Remarks on Locke's Account of Knowledge, „Locke Newsletter” 3(1972), 7-17. Por. J.L. Mackie, Locke and Representative Perception, w: Logic and Knowledge. Selected Papers, t. 1, red. J.L. Mackie, Oxford 1985, 214-224. Na temat relacji Locke'a do szeroko pojętej filozofii zdrowego rozsądku zob. M. Ben-Chaim, Locke's Ideology of „Common Sense”, Studies in History and Philosophy of Science 31(2000)3, 473-501; S. Zabieglik, Krzywe zwierciadło filozofii czyli dzieje pojecia zdrowego rozsądku, dz. cyt., 115-116; M.V.C. Jeffreys, John Locke. Prophet of Common Sense, London 1967. Por. P.K. Szałek, Zagadnienie sceptycyzmu w kontekście wptywu myśli Locke'a na filozofię Berkeleya, Roczniki Filozoficzne 58(2010)1, 229-246.

${ }^{144}$ Wydaje się, że Locke preferuje fizykalistyczne rozumienie substancji, ceniąc wyżej teorię korpuskularną niż filozoficzne rozumienie substratum, pojęte jako podłoże przypadłości. Uważa bowiem, że idea substancji jest niejasna, gdyż jest odnoszona do tak różnych substancji, jak Bóg, umysł czy ciała, że wręcz można ją uznać za przykład hipostazowania. Faktycznie jednak ją przyjmuje, choćby tylko w sensie mętnej idei, ujmującej substancję w aspekcie funkcji, jaką ona pełni. Bo choć traktuje rzeczy jako kombinację prostych idei, reprezentujących poszczególne rzeczy, istniejące samodzielnie, to godzi się choćby na założenie (suppose) o istnieniu (niewyraźnej) idei substancji, która ma przecież charakter ,pierwszy i główny”. Godzi się więc ze zwyczajem, by to w substancji znaleźć podmiot, w którym tradycyjnie pojęte przypadłości mogłyby subsystować, na co mają wskazywać nawet eksperyment i obserwacja, ujmujące je jako istniejące razem. Jednak z drugiej strony, nie zawaha się odwołać do hipotezy korpuskularnej, upatrując źródło właściwości ciał w strukturze i ruchu cząsteczek, choć tylko w niektórych przypadkach jesteśmy zdolni do wykrycia tej zależności. Tym samym można przypuszczać, że przynajmniej w pewnej mierze to do tego układu 


\section{akceptację argumentacji za istnieniem Boga ${ }^{145}$. To epistemologiczne}

cząstek odnosi założenie (suppose), że właściwości poszczególnych ciał, odróżniające je od innych, wypływają ze szczególnego ustroju wewnętrznego lub nieznanej istoty. J. Locke, Rozważania dotyczace rozumu ludzkiego, dz. cyt., t. 1, 212-213, 225-228, 407-410, 435-436; t. 2, 227-229; Tenże, An Essay Concerning Human Understanding, dz. cyt., t. 1, 156, 166-167; t. 2, 1-10, 28-29, 366-367. Zob. Corpuscular hypothesis; Substance, w: J.W. Yolton, A Locke Dictionary, Oxford 1993, 53-54, 281-287. W kwestii fizykalistycznego rozumienia substancji lub też dostrzegania śladów filozoficznej wizji substancji w ujęciu Locke’a zob. zwłaszcza: R.S. Woolhouse, Locke’s Philosophy of Science and Knowledge. A Consideration of Some Aspects of „An Essay Concerning Human Understanding”, Oxford 1971, 117-120, 127-143. Por. np. P. Alexander, Locke on Substance-in-General, Ratio 22(1980), 91-105; 23(1981), 1-19; M.R. Ayers, The Ideas of Power and Substance in Locke's Philosophy, Philosophical Quarterly 25(1975), 1-27; J.L. Bermúdez, Locke. Metaphysical Dualism and Property Dualism, British Journal for the History of Philosophy 4(1996), 223-245; R. McCann, Locke's Philosophy of Body, w: The Cambridge Companion to Locke, red. V. Chappell, Cambridge 1999, 56-88; F.J. Pelletier, Locke's Doctrine of Substance, Canadian Journal of Philosophy (suppl.) 4(1978), 121-140; M.B. Bolton, Substances, Substrata, and Names of Substances in Locke's „Essay”, w: Locke, red. V. Chappell, Oxford 1998, 86-105; M.B. Bolton, Substratum, w: Tamże, 129-148; T. Kubalica, John Locke i George Berkeley wobec problemu istoty poznania, Idea - Studia nad strukturą i rozwojem pojęć filozoficznych 24(2012), 37-58. Por. Substanz. Neue Überlegungen zu einer klassischen Kategorie des Seienden, red. K. Trettin, Frankfurt am Main 2005.

145 Operując psychologicznym podejściem w badaniu źródeł poznania, Locke oprócz intuicji i dedukcji - wyróżniał jeszcze trzeci typ wiedzy, jakim jest doświadczenie zmysłowe. O ile bowiem dwie pierwsze metody, choć posługiwały się ideami mającymi korzenie empiryczne, to przecież ich analiza - tożsama z knowledge-miała charakter czysto intelektualny. Ostatni typ wiedzy ma być bezpośrednio zależny od doświadczenia, ale dotyczyć jedynie stwierdzenia istnienia świata pozapodmiotowego, z wyjątkiem istnienia siebie i Boga, bo pierwsze ma charakter intuicyjny, a drugie demonstratywny, gdy wiedza o istnieniu ciał jest tylko prawdopodobna (J. Locke, Rozważania dotyczace rozumu ludzkiego, dz. cyt., t. 2, 226; Tenże, An Essay Concerning Human Understanding, dz. cyt., t. 2, 373). Nawet jednak w tym przypadku, choć nie wychodzi ona poza gołe prawdopodobieństwo (szerzej w rozdz. 15 O prawdopodobieństwie. Zob. J.W. Yolton, Probability, w: Tenże, A Locke Dictionary, dz. cyt., 175-177), to przecież świadomość w zakresie pochodzenia idei mającej swe źródło w doświadczeniu świata pozapodmiotowego ma być tak oczywista (evidence) i nieodparta (invincibly conscious), że pośrednio uwalnia nas od wątpienia. J. Locke, Rozważania dotyczace rozumu ludzkiego, dz. cyt., t. 2, 211-213; Tenże, An Essay Concerning Human Understanding, dz. cyt., t. 2, 327-328. Szerzej w rozdz. 11 księgi IV „O naszej wiedzy dotyczącej istnienia innych rzeczy”, bowiem w rozdz. 9 i 10 tej 
podejście będzie charakterystyczne dla wielu przedstawicieli filozofii podmiotu, aż po Hegla ${ }^{146}$. Ujęcie Reida, tak jak i Pascala było bardziej metafilozoficzne, niż przedmiotowe. Jeśli więc myśliciel z Port-Royal nie zbudował systemu metafizyki, to przecież nie wykluczał takiej możliwości, jak Reid, koncentrując się na epistemologii i etyce, których problematyka była przecież najbliższa także Pascalowi ${ }^{147}$. Dla obydwu filozofów fundamentalny charakter miała problematyka z zakresu epistemologii i etyki. Jeśli jednak myśliciel z Port-Royal nie zbudował systemu metafizyki, to przecież nie wykluczał takiej możliwości, jak Reid, o czym świadczy jego praktyka dydaktyczna.

\section{EPILOG OŚWIECENIOWY}

Aprioryzm i intuicjonizm Reida nie był na Wyspach Brytyjskich zjawiskiem odosobnionym. Uwidocznił się zwłaszcza w dokonaniach Henry'ego More'a ${ }^{148}$ czy Ralpha Cudwortha ${ }^{149} \mathrm{w}$ formie obrony racjonalizmu w imię uprawomocnienia apriorycznych fundamentów teologii $\mathrm{i}$ etyki, przez zespolenie lumen naturale $\mathrm{z}$ objawieniem religijnym.

księgi, podjął kolejno kwestię uzasadnienia naszej egzystencji i istnienia Boga (rozdz. Nasza wiedza o istnieniu, rozdz. 10: O naszej wiedzy o istnieniu Boga). Zob. hasła Cause i Scepticism, w: J.W. Yolton, A Locke Dictionary, dz. cyt., 34-35, 246-248.

${ }^{146}$ Zob. W. Chudy, Hegla metafizyka pojęcia absolutnego, w: Metafizyka w filozofii (seria: Zadania współczesnej metafizyki, nr 6), red. A. Maryniarczyk, K. Stępień, Lublin 2004, 321-373.

${ }^{147}$ Gdy się rozważania zatytułowane w Unsprüngliche Wörter und Definition umieści się w kontekście Theorie und Praxis der Sprache, to wówczas można myśl Pascala interpretować także np. w kategoriach zapowiadających filozofię Edmunda Husserla. Choć dostrzeże się wówczas transcendentny charakter terminów czy zasad pierwotnych, w pierwszym przypadku w traktacie $O$ geometrycznym sposobie $m y$ ślenia, w drugim w Myślach, to jednak zagubi się ich interpretacja metafizyczna, jak w przypadku Platona czy Kartezjusza. Terminy i zasady pierwotne będą bowiem tylko ludzkimi artefaktami. R.H. Ziegler, Buchstabe und Geist. Pascal und die Grenzen der Philosophie, Göttingen 2010, 181-210.

${ }^{148}$ H. More, Opera omnia, Londini 1679. More popularyzował kartezjanizm już od roku 1744. Zob. C.L. Thijssen-Schoute, Nederlands Cartesianisme, Amsterdam 1954, $13 \mathrm{nn}$.

${ }^{149}$ R. Cudworth, The True Intellectual System of the Universe, London 1678. Zob. G.A.J. Rogers, Die Cambridger Platoniker, dz. cyt., 267-272. 
W doktrynie dotyczącej idei wrodzonych, choćby pojmowanej tylko w sensie potencjalnym, w formie różnie określanych notiones communes czy notitiae communes, głoszonej przez Edwarda Herberta of Cherbury ${ }^{150}$, widziano warunek koniecznego charakteru prawd dotyczących istnienia i natury Boga czy duszy ludzkiej, a przede wszystkim prawomocności prawa naturalnego, co uwidoczniło się w poglądach także zwolenników religii naturalnej, domagających się pierwszeństwa prawa naturalnego przed objawieniem. Przeprowadzona przez Johna Locke'a krytyka natywizmu ${ }^{151}$ musiała być więc bardzo ostrożna, skoro dotykała pośrednio zagadnień mających odniesienia światopoglądowe (religijno-moralne) $^{152}$. W zgodzie z paradygmatem empiryzmu genetycznego Locke wskazywał na brak powszechnej znajomości prawd

${ }^{150} \mathrm{E}$. Herbert of Cherbury, De veritate, prout distinguitur a revelatione, a verisimili, a possibili, et a falso, Parisiis 1624. Por. D.A. Pailin, Herbert von Cherbury, w: Die Philosophie des 17. Jahrhunderts, dz. cyt., 224-239, 284-285. Podobnie Cudworth podkreśla rolę unifikujących dane poznania zmysłowego rozmaitych apriorycznych nomemata z zakresu logiki, etyki czy nawet metafizyki. Zob. S. Raube, Deus explicatus. Stworzenie i Bóg w myśli Ralpha Cudwortha, Białystok 2000.

${ }^{151}$ G. Wall, Locke's Attack on Innate Knowledge, „Philosophy” 49(1974), 414-419; toż w: Locke on Human Understanding, red. I.C. Tipton, Oxford 1977, 1-18); S.J. Winchester, Locke and the Innatists, History of Philosophy Quarterly 2(1985), 411-420; D. Greenlee, Locke and the Controversy over Innate Ideas, Journal of the History of Ideas 33(1972), 251-264; R.W. Adams, Where Do Our Ideas Come From? Descartes vs. Locke, w: Innate Ideas, red. S.P. Stich, Berkeley 1975, 71-87; Tenże, The LockeLeibniz Debate, w: Tamże, 37-57; J. Harris, Leibniz and Locke on Innate Ideas, Ratio 16(1974), 226-242; G.A.J. Rogers, Locke, Newton, and the Cambridge Platonists on Innate Ideas, Journal of the History of Ideas 40(1979), 191-205.

${ }^{152}$ Wbrew stanowisku R.I. Aarona, który widział w Kartezjuszu głównego adwersarza polemiki przeprowadzonej przez Locke'a, J.W. Yolton wyakcentuje przede wszystkim rolę brytyjskiego natywizmu jako podstawowego odniesienia krytyki dokonanej przez Locke'a. Zob. R.I. Aaron, John Locke, Oxford 19552, 26-28, 83-98; J.W. Yolton, John Locke and the Way of Ideas, Oxford 1956, 26-71. Por. Z. Ogonowski, Locke, Warszawa 1972, 226-233; G.A.J. Rogers, Locke, Newton, and the Cambridge Platonists on Innate Ideas, Journal of the History of Ideas 40(1979), 191-205; G. von Hertling, John Locke und die Schule von Cambridge, Freiburg im Breisgau 1892. Na temat całościowo potraktowanego środowiska szkoły w Cambridge zob. G.A.J. Rogers, Die Cambridger Platoniker, w: Die Philosophie des 17. Jahrhunderts, dz. cyt., 240-290; S. Weyer, Die Cambridge Platonists. Religion und Freiheit in England im 17. Jahrhundert, Frankfurt am Main 1993. 
określanych przez natywistów jako wrodzone, a tym samym na ich relatywną trwałość ograniczoną specyfiką wychowania i historycznie zmiennej tradycji ${ }^{153}$. Mimo niewątpliwej preferencji empiryzmu w jego dokonaniu nie sposób nie dostrzec jednak - paradoksalnie - pewnych śladów poglądów typowych dla tradycji kartezjańskiej. Dotyczy to już znaczenia jakie wyznaczał ugruntowanej w racjonalizmie intelektualnej intuicji, jako swoistego doświadczenia wewnętrznego, i to w zakresie tak wartościowej wiedzy jak badanie stosunków między ideami ${ }^{154}$.

W oświeconej Francji, myślicielem, który najwcześniej godził empiryzm brytyjski z rodzimą tradycją racjonalistyczną był Claude Buffier, jezuicki reformator szkolnictwa. Jest on uznawany nie bez podstaw za jednego z pionierów filozofii zdrowego rozsądku, doceniający elementy wiedzy apriorycznej. Podkreślając rolę refleksji epistemologicznej, traktował oryginalnie rozważania Johna Locke’a jako przejaw „une vraie

${ }^{153}$ Rozbudowana krytyka natywizmu jest zawarta w księdze I głównego traktatu epistemologicznego Locke'a Rozważania dotyczace rozumu ludzkiego, dz. cyt., t. 1, 30-118; Tenże, An Essay Concerning Human Understanding, dz. cyt., t. 1, 13-81.

${ }^{154}$ Choć Locke podkreśla rolę szeroko pojętej percepcji, także w sensie aktu refleksyjnego dotyczącego posiadania idei, stąd będącej synonimem thinking, nietrudno zauważyć, że tak pojęta percepcja jest zbieżna z kartezjańską intuicją (intuitive knowledge). Dokonuje się bowiem bez wysiłku i wnioskowania, na pierwsze wejrzenie (at first view), dzięki naturalnej zdolności postrzegania i rozróżniania, a nade wszystko w sposób jasny i nieomylny (infability). Posługując się konsekwentnie żargonem asocjacjonizmu, Locke stwierdzi, że jesteśmy skazani na dowodzenie, gdy nie możemy tak zestawić idei, by przez bezpośrednie porównanie dostrzec (perceive) zachodzącą między nimi zgodność lub jej brak, a osiągamy to dopiero za pośrednictwem innej idei (jednej lub więcej), w formie rozumowania, stanowiącego w istocie dowód. Ową zgodność lub niezgodność idei dostrzega umysł, w tym przypadku jednak nie bez trudu i pilności. Pierwszeństwo intuicji przed dowodem ujawnia się również przez podjęcie - charakterystycznej także dla Kartezjusza - próby sprowadzenia tej pośredniej argumentacji do ciągu intuicji, który zachodziłby w odniesieniu do poszczególnych stopni poznania w formie dostrzeżenia bezpośredniej zgodności idei pośredniczących (intermediate idea), gdyż inaczej każdy element dowodu wymagałby sam dowodu. Dzięki temu możliwe będzie stwierdzenie zgodności między ideami stojącymi na początku cyklu dowodowego. Locke powstrzyma się jednak przed przypisaniem tej ostatecznie udokumentowanej zgodności charakteru intuicyjnego, co było charakterystyczne dla Kartezjusza, jest więc bliższy koncepcji rozumowania charakterystycznej dla tradycyjnej logiki. 
métaphysique, mais plausible". Równocześnie podkreślał znaczenie pierwszych prawd (premiére vérité) jako fundamentu wszelkiej wiedzy, odkrywanej przy pomocy swoiście rozumianego zmysłu wspólnego (sens commun). W tej perspektywie metafizyka ma koncentrować się na analizie natury bytu i jego rodzajów, przy czym właśnie istnienie Boga jest jedną $z$ owych ,pierwszych prawd”155. Ze względu na filiacje z Lockiem cenił Buffiera sam Wolter, który z czasem upowszechniał poglądy oświeconego Anglika. Niechętny programowo jezuitom w Le Siècle de Louis XIV włączył Buffiera do „Catalogue de la plupart des écrivains", uznając jego metafizykę jako możliwą do zaakceptowania przez Locke'a (philosophie raisonable) ${ }^{156}$. Istotną oznaką znaczenia tego typu myślenia w oświeconej Francji jest wykorzystanie dokonania Buffiera przez Encyclopédie ou dictionnaire universel, która dokumentowała i projektowała ówczesną kulturę intelektualną. Tym bardziej zwraca uwagę, że do filozofii uczonego jezuity odwoływano się w hasłach dotyczących programu szkół reformowanych przez ówczesne państwo, zwłaszcza, że w oświacie publicznej - nie kto inny, jak Jean J. Rousseau w haśle Économie - widział ,la plus importante affaire de

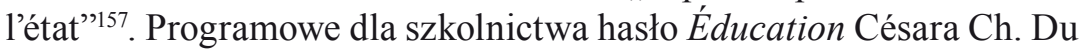
Marsais odsyła do sformułowań Traité des premières vérités $\mathrm{w}$ istot-

${ }^{155}$ C. Buffier, Traité des premieres veritez, et de la source de nos jugements, ou l'on examine le sentiment des philosophes de ce temps, sur les premiéres notions des choses, Paris 1724; Tenże, Elemens de métaphysique, a la porte de tout le monde, Paris 1725; wydane także w ramach Cours de sciences sur des principes nouveaux et simples, pour former la langage, l'esprit et le cour dans l'usage ordinaire de la vie, Paris 1732; cyt wg reprintu Cours de sciences. Sur des principes nouveaux et simples pour former le langage, l'esprit et le cour, dans l'usage ordinaire de la vie, suivi de Homère en arbitrage, Genève 1971. Zob. S. Zabieglik, Krzywe zwierciadto filozofii czyli dzieje pojęcia zdrowego rozsądku, dz. cyt., 102-105.

${ }^{156}$ Voltaire, Le Siècle de Lois XIV, Berlin 1784, 566. Cyt. za: L. Marcil-Lacoste, Claude Buffier and Thomas Reid. Two Common-Sense Philosophers, Kingston 1982, 11; K.S. Wilkins, A Study of the Works of Claude Buffier, Genève 1969, 95. Por. J.A. Ventosa Águilar, El Sentido común en las obras filosóficas del P. Claude Buffier, S. I. Contribución a la historia de la filosofía del sentido común, Barcelona 1957.

157 J.J. Rousseau („Article de M. Rousseau, citoyen de Genève”), Économie ou Economie, w: Encyclopédie ou dictionnaire universel raisonné des sciences, des arts et des métiers, par une société de gens de lettres. Mis en ordre et publié par... [Denis] 
nej kwestii podstaw metafizycznych wychowania ${ }^{158}$. Nieprzypadkowo także w haśle Logique ${ }^{159}$ widziano w Buffierze autora ,une excellente logique"160, stąd - zapewne - dokonanie to zaleciła polska KEN, dla której właściwa kultura intelektualna i moralna była podstawowym celem wychowania i nauczania ${ }^{161}$.

Odwołanie się przez Encyklopedię do idei filozofii zdrowego rozsądku nabiera wagi, gdy uwzględni się fakt, że jej sekretarzem naukowym był Jean Le Rond d'Alembert, wybitny matematyk i fizyk, ale także filozof, a zwłaszcza metodolog nauki ${ }^{162}$. Wskazując na złożony metodologicznie charakter ówczesnych nauk, które nierzadko nie mogły urzeczywistnić wymogów stawianych matematycznemu przyrodoznawstwu, sformułował on klasyfikację nauk stwierdzając, że spektrum nauk jest ograniczone przez „dwie strefy krańcowe”. Jednym z tych punktów

Diderot et quant à la partie mathématique par...... [Jean le Rond] D'Alembert, t. 1-35, Paris 1751-1780; cyt jako przedruk - Stuttgart 1966-1995, t. 5, 362.

${ }^{158}$ C.Ch. Du Marsais (sygnowany jako „F”), Éducation, w: Encyclopédie ou dictionnaire universel, dz. cyt., t. 5, 397; por. Tamże, 397-340.

${ }^{159}$ W: Encyclopédie ou dictionnaire universel, dz. cyt., t. 9, 637-641. Zob. S. Janeczek, Koncepcja logiki w ,Wielkiej Encyklopedii Francuskiej”. Studium z historii recepcji, Studia Philosophiae Christianae 46(2010)2, 5-24; Tenże, Dydaktyka logiki w szkołach KEN a koncepcja logiki w ,Wielkiej Encyklopedii Francuskiej”, Rocznik Historii Filozofii Polskiej 4/5(2011/2012), 105-134.

${ }^{160} \mathrm{Wg}$ autora hasła Logique, Buffier miał pisać w sposób gruntowny o kwestiach nawet najbardziej abstrakcyjnych w sposób łatwy, a nawet zabawny. W: Encyclopédie ou dictionnaire universel, dz. cyt., t. 9, 639.

${ }^{161}$ „Do logiki Komisja zaleca czytanie logiki p. Buffier, p. Clerc, Antonii Genuensis Elementa Artis Logico-Criticae, dzieła Loka i Condillac". Przepis Komisji Edukacji Narodowej na szkoły wojewódzkie, w: Ustawodawstwo szkolne za czasów Komisji Edukacji Narodowej. Rozporzadzenia, ustawy pedagogiczne i organizacyjne (1773-1793), wyd. J. Lewicki, Kraków 1925, 34. C. Buffier jest m.in. autorem podręcznika logiki Les principes du raisonement exposés en deux logiques nouvéles avec des ramarques sur les Logiques qui ont eu le plus de réputation de notre temps (Paris 1714); cyt. za: Tenże, Traité des premieres veritez de conséquence, ou les principes du raisonement, w: Cours de sciences, dz. cyt., 745-892. Zob. S. Janeczek, Z dziejów dydaktyki logiki w szkołach KEN. Claude Buffier SJ, Roczniki Filozoficzne 56(2008)2, 83-99.

${ }_{162}$ Zob. S. Janeczek, Z dziejów kultury naukowej. Koncepcja nauki Jean le Rond d'Alemberta, Roczniki Kulturoznawcze 4(2013)1, 59-92; Tenże, Prepozytywizm filozofii Jean le Rond d'Alemberta?, Zeszyty Naukowe KUL 55(2012)2(218), 3-24. 
granicznych są naturalnie nauki matematyczne, także w zakresie analizy najogólniejszych własności ciał, „opatrzone piętnem oczywistości”, gdy drugi kraniec bogatej działalności naukowej wyznaczają prawdy stanowiące fundamentalne tezy filozofii, a więc ,idea nas samych, prowadząca do idei Bytu Wszechmocnego i zasadniczych naszych obowiązków”. Prawdy te znane są bądź to na gruncie objawienia, i wówczas ich pewność jest nieporównanie większa niż rozstrzygnięcia filozoficzne ${ }^{163}$, bądź też mają charakter zdroworozsądkowy, gdyż są przyjmowane na drodze naturalnej skłonności o charakterze instynktowym. Ten drugi przypadek odnosi się do usankcjonowania realizmu w metafizyce opartej na reprezentacjonistycznej epistemologii w formie realizmu pośredniego. Choć d'Alembert przyzna, że niemożliwe jest racjonalne udowodnienie przyczynowego ,związku między danym wrażeniem a wywołującym je przedmiotem”, to przecież równocześnie zaznaczy, że prawdę tę możemy przyjąć ,bez wahania” na podstawie skłonności (inspiration) czy ,pewnego rodzaju instynktu” (instinct), którego głos ma być nawet pewniejszy nawet niż rozumu pojętego dyskursywnie ${ }^{164}$.

Wskazanie na obecność wątków intuicjonistycznych w twórczości d'Alemberta ${ }^{165}$ wydaje się usprawiedliwione także na gruncie rozważań dotyczących bliskiej Pascalowi refleksji na temat ducha filozoficznego, przekraczającego dyskursywny racjonalizm matematyki. Według sekretarza Encyklopedii, o ile w badaniach przyrodniczych musi się w równej mierze ujawnić cierpliwość wobec rejestracji faktów, co i odwaga w zakresie twórczych badań, a więc stawianie hipotez, to

${ }^{163}$ J. le Rond d'Alembert, Discours préliminaire de l'Encyclopedie, w: Euvres complètes de d'Alembert, red. A. Belin, t. 1-5, Paris 1821-1822; cytowane za reprintem-Genève 1967, t. 1, 29-31; Tenże, Wstęp do Encyklopedii, tłum. z franc. J. Hartwig, Warszawa 1954, 25-27.

${ }^{164}$ J. le Rond d'Alembert, Discours préliminaire de l'Encyclopedie, w: Euvres complètes de d'Alembert, dz. cyt., t. 1, 19-20; Tenże, Wstęp do Encyklopedii, dz. cyt., 8-10. Por. Tenże, Essai sur les élements de philosophie, ou sur les principes des connaissances humaines, w: Mélanges de littérature, d'histoire et de philosophie, t. 4, Amsterdam 1759; toż w: Euvres complètes de d'Alembert, dz. cyt., t. 1, 181-185.

165 Zob. S. Janeczek, Teoria nauki w ujęciu J. le Ronda d'Alemberta. Między empiryzmem, racjonalizmem i intuicjonizmem, w: Philosophia vitam alere. Prace dedykowane Profesorowi Romanowi Darowskiemu SJ, Kraków 2005, 199-212. 
w dziedzinie rozstrzygnięć praktycznych oczywistość umysłu musi być zastąpiona przez evidence du coeur ${ }^{166}$. Równocześnie d'Alembert wyróżnił dwa typy umysłowości: $1^{0}$ esprit purement géometrique, który ma ograniczony zasięg, bowiem jedynie do tego, co jest bezpośrednio dane, oraz $2^{0}$ esprit géometrique, który chce objąć swym zasięgiem całość poznania, a więc także sferę pozostającą w „mroku i daleko”, czyli także wtedy, gdy nie tylko potrafi ją rozpoznać z bliska, ale i przeczuć jej istnienie i dostrzec ją z daleka, gdy jest jeszcze „ulotna”. Ta właściwie pojęta sprawność (véritable esprit philosophique), stanowiąca synonim elastyczności umysłu - bowiem d'Alembert określa ją jako „przewidywanie i wyczuwanie prawdy” - jest bliska esprit de finesse i esprit droit w ujęciu Pascala. Umożliwia bowiem formułowanie zasad, czyli „wyciąganie wniosków z niewielu zasad”, oraz, „wnikanie żywo i głęboko w konsekwencje zasad”. Odznacza się zaś „siłą i trafnością,"167. Fundamentalną funkcją szeroko pojętego „ducha filozoficznego”, różnego od procedur dyskursywnych, miało być dla d'Alemberta - analogicznie jak dla Pascala - odkrycie pierwotnych zasad, które stanowią swoisty „depozyt metafizyki”. Obejmuje ona jednak nie tylko kategorie tradycyjnej ontologii czy pneumatologii ${ }^{168}$, jak u Reida, ale także pryncypia poszczególnych nauk, bowiem ,nie ma nauki, która nie miałaby swojej metafizyki", stanowiącej zasady specyficzne dla każdej nauki ${ }^{169}$. Podstawą ich przyjęcia są nie tyle skomplikowane zabiegi heurystyczne, czyli droga ,analizy” czy „rachunku”, ile raczej droga instynktowna,

166 J. le Rond d'Alembert, Discours préliminaire de l'Encyclopedie, dz. cyt., 43; Tenże, Wstęp do Encyklopedii, dz. cyt., 46; Tenże, Essai sur les élements de philosophie, w: Euvres complètes de d'Alembert, dz. cyt., t. 1, 137, 234. Por. A. Schober, D'Alembert de vermeintliche Vater des Positivismus. Eine historisch-systematische Untersuchung, Erlangen 1982, 176-177.

167 J. le Rond d'Alembert, Essai sur les élements de philosophie, dz. cyt., 154, 186. Por. A. Schober, D'Alembert der vermeintliche Vater des Positivismus, dz. cyt., 48-55.

${ }^{168}$ Tenże, Discours préliminaire de l'Encyclopedie, dz. cyt., 49; Tenże, Wstęp do Encyklopedii, dz. cyt., 55-56.

169 Tenże, Essai sur les élements de philosophie, dz. cyt., 391. 
której „musimy zaufać bez sprzeciwu” ${ }^{\text {”170 }}$, bowiem instynkt jest „pełniejszy niż sam rozum”, co „popycha nas do wykonania skoku”"171.

Charakterystyczny dla d'Alemberta kartezjański rys metodologii, $\mathrm{w}$ formie sygnalizowanego odwołania się do podstawowego wyróżnika wartościowej wiedzy jakim jest oczywistość (o charakterze podmiotowym), był właściwy także encyklopedycznemu hasłu Science ${ }^{172}$. Co więcej, był właściwy nawet tak zdecydowanemu sensualiście, jakim był Ėtienne Condillac ${ }^{173}$. Według Isabel F. Knight w metodologii Condillaca uwidaczniają się dwa - zresztą splecione ze sobą - sposoby urzeczywistnienia systemowej wizji rzeczywistości, bo na drodze $1^{0}$ logiki charakterystycznej dla analizy algebraicznej, która odwołuje się do ideału identyczności, oraz $2^{0}$ empirycznej weryfikacji przez obserwację i eksperyment, przy czym sprzężenie tych sposobów wynika z naszych ograniczeń poznawczych. W szczególności jest niezbędny drugi sposób, gdyż w pełni analityczne ujęcie możliwe jest tylko dla nieskończonego umysłu $^{174}$. Ta metodologiczna postawa bodaj najbardziej lapidarnie została ukazana w De l'art de raisonner ${ }^{175}$, gdzie Condillac podjął problematykę poznania pewnego w odniesieniu do tak cenionych podówczas nauk przyrodniczych. Określił wówczas trzy typy oczywistości, z których każdy posiada właściwe sobie metody weryfikacji, funkcje

${ }^{170}$ Tenże, Essai sur les élements de philosophie, dz. cyt., 187.

${ }^{171}$ J. le Rond d'Alembert, Discours préliminaire de l'Encyclopedie, dz. cyt., 20; Tenże, Wstęp do Encyklopedii, dz. cyt., 9.

172 „Science, en terme de philosophie, signifie la connoissance claire \& certaine de quelque chose, fondée ou sur des principes évidens par eux - mêmes, ou sur des démonstrations". L. de Jacourt, Science (Logiq. \& Métaphys.), w: Encyclopédie ou dictionnaire universel, dz. cyt., t. 14, 787. Zob. W. Starzyński, Kartezjańskie motywy filozofii oczywistości. Analiza hasła „Evidence” Wielkiej Encyklopedii Francuskiej autorstwa François Quesnaya, Archiwum Historii Filozofii i Myśli Społecznej 53(2008), 65-92.

${ }^{173}$ Zob. S. Janeczek, Kartezjanizm teorii nauki É. Condillaca, w: Filozofia XVII wieku i jej kontynuacje, red. Z. Drozdowicz, Poznań 2009, 203-209.

${ }^{174}$ I.F. Knight,The Geometric Spirit. The Abbé de Condillac and the French Enlightenment, New Haven 1968, 74.

${ }^{175}$ É. Condillac, De l'art de raisonner, w: Cours d'études pour l'instruction du prince de Parme, t. 13, Parma [właśc. Paris] 1775; toż w: Euvres philosophiques de Condillac, t. 1, red. G. Le Roy, Presses universitaires de France, Paris 1947, 619-714. 
i ograniczenia, a więc oczywistość faktu (évidence de fait), oczywistość czucia wewnętrznego (évidence de sentiment) i oczywistość rozumu (évidence de raison). Odpowiadają one trzem prawomocnym metodom, które uzupełnił jedynie o analogię ${ }^{176}$. Choć Condillac operuje kategorią

176 Skrótem rozważań dotyczących problematyki zróżnicowanych typów oczywistości i związanych z nimi metod w nauce jest część I rozdz. IX w części II Logique, gdzie Condillac odsyła do De l'art de raisonner, która ma być „obszerniejszym całego tego rozdziału wykładem”. W Logice ograniczy się do lapidarnego (kilkustronicowego) przedstawienia tej problematyki, w gruncie w rzeczy w formie przystępnego wyjaśnienia terminów używanych w teorii poznania i metodologii nauk, uzupełnianego o równie przystępne przykłady. Polski tłumacz podręcznika logiki Condillaca oddaje jednak niezbyt szczęśliwie francuskie dookreślenia trzech typów oczywistości. Termin évidence de fait przedkłada jako „oczywistość czynów”, mimo że nawet przytoczona w przekładzie łacińska nazwa tej kategorii wskazuje na szeroko pojętą sferę zdarzeń, jako factum (evidentia facti). Podobnie bardziej konsekwentne byłoby oddanie évidence de sentiment jako „oczywistość odczuwania” w zakresie percepcji stanów wewnętrznych, wyrażana przez kategorię evidentia sensus intimi, a więc w sensie czucia wewnętrznego, które pozostaje w zgodzie z tłumaczeniem wyrazu sensation jako „czucie”, stosowanym we wszystkich przekładach pism Condillaca. Wreszcie, choć rzeczywiście określenie „oczywistość rozumowania” dobrze oddaje termin evidence de raison, w sensie dyskursu, to przecież uwzględniając teoriopoznawczometodologiczny aspekt tych rozważań, właściwsze byłoby chyba oddanie tej nazwy jako „oczywistość rozumu”, zwłaszcza gdy będzie ona służyła na określenie operacji racjonalnych, wzorowanych na procedurach algebry. Wątpliwości związane z ową nomenklaturą wynikają z oparcia się głównie na skrótowych wyjaśnieniach zawartych w Logique, które wszakże odsyłają do gruntowniejszego przedstawienia w De l'art de raisonner, choć trzeba dodać sprawiedliwie, że tłumacz uzupełnił podręcznik Condillaca właśnie o wybrane elementy z przywoływanej pracy, przede wszystkim w zakresie dwóch pozaracjonalnych sposobów „rozumowania”, niedostatecznie wyjaśnionych w podręczniku logiki. Poczynienie tych modyfikacji terminologicznych wydaje się zasadne także z tego względu, że zarówno Logique, jak i De l'art raisonner operują terminem 'rozumowanie' (raisonner, raisonnement) w sensie szerszym, obejmującym trzy rodzaje poznania związane z trzema typami oczywistości, choć w pierwszym z wymienionych opracowań wydaje się, że Condillac skłonny jest rozumieć 'rozumowanie' przede wszystkim w sensie wiedzy modelowej związanej z evidence de raison, zaczerpniętej z czysto racjonalnych operacji algebraicznych, dodając, że powinny być one traktowane jako metoda o charakterze uniwersalnym. É. Condillac, La Logique ou les premiers développements de l'art de penser, Paris 1780; toż cyt. w: Euvres philosophiques de Condillac, dz. cyt., t. 2, Paris 1948, 409-413; toż jako: Logika czyli pierwsze zasady sztuki myślenia, dzieło elementarne... na żądanie bywszej Komisji 
oczywistości jako synonimem poznania pewnego, to przecież okaże się, że praktyczne jej urzeczywistnienie jest rzeczą niezmiernie trudną, stąd też integralnie ujęta metodologia musi zespalać trzy, a właściwie cztery postawy metodologiczne, które wzajemnie się wspomagają i sprawdzają ${ }^{177}$. Rzetelność wymaga dodania, że mimo kartezjańskiego rysu dokonania Condillaca, kategorię instynktu odnosi on tylko do specyfiki zachowań zwierząt. Jest to tylko nawyk zrodzony na kanwie doświadczenia stymulowanego potrzebami i poczuciem przyjemności i bólu, przy czym zwierzęta zdolne są nie tylko do poznania pojętego czysto receptywnie, ale także do aktów refleksyjnych, a tym samym do pewnej formy myślenia abstrakcyjnego, chociaż nie w takim stopniu, jak jest to właściwe człowiekowi. Jest bowiem ono ograniczone tylko do świata ich potrzeb i środowiska, które jest przedmiotem ich doświadczenia. Ostatecznie zaś o specyfice człowieka ma rozstrzygać jego zdolność poznania Boga i akty o charakterze moralnym ${ }^{178}$. Analogicznie wątki biologiczne podejmuje encyklopedyczne hasło

Edukacyjnej Narodowej dla szkót publicznych napisane i od niej aprobowane, a teraz z przydatkiem niektórych objaśnień i przypisów przez Jana Znoskę z francuskiego na polski język przełożone, Wilno 1802, 18193; cyt. w wyd. współcz, jako Logika, red. T. Kotarbiński, Warszawa 1952, 137-148, 174-180.

${ }^{177}$ Zob. S. Janeczek, Logika czy epistemologia?, dz. cyt., 534-564.

178 „L'instinct n'est rien, ou c'est un commencement de connoissance: car les actions des animaux ne peuvent dépendre que de trois principes; ou d'un pur mecanisme, ou d'un sentiment aveugle qui ne compare point, qui ne juge et qui connoît. Or j'ai démontré que les deux premiers principes sont absolument insuffisans... Dès [bêtes - S.J.] forment peu abstractions, elles ont peu d'idées générales: presque tout n'est qu'individu pour elles. Par la nature de leurs besoins, il n'y a que les objets extérieurs qui puissent les intéresser. Leur instinct les entraîne toujours audehors, et nous ne découvrons rien qui puisse les faire réfléchir sur elles pour observer ce qu'elles sont. L'homme, au contraire, capable d'abstractions de toute espèce, peut se comparer avec tout ce qui l'environne. Il rentre en lui-même, il en sort; son être et la nature entière deviennent les objets de ses observations: ses connoissances se multiplient: les arts et les sciences naissent, et ne naissent que pour lui. Voilà un champ bien vaste: mais je ne donnerai ici que deux exemples de la supériorité de l'homme sur les bêtes; l'un sera tiré de la connoissance de la divinité, l'autre de la connoissance de la morale". É. Condillac, Traité des animaux, w: Euvres philosophiques de Condillac, dz. cyt., t. 1, 362-365. 
Instynk ${ }^{179}$, jednak Encyklopedia zachowuje zakorzenione w tradycji hasło Prawdy wieczne ${ }^{180}$, a co ważniejsze hasło Bon-sens ${ }^{181}$. W obu przypadkach podkreśla jednak rolę doświadczenia, które stymuluje naturalne usprawnienia. Bon-sens odnoszony jest zasadniczo do działalności o charakterze praktycznym (,affaires ordinaires de la société”), jeśli jednak jego zakres jest ujmowany przy pomocy takich kategorii jak „sens, sens-commun, bon-sens, esprit, jugement, pénétration, sagacité, génie, \& tous les autres termes qui marquent soit l'étendue, soit la sorte d'intelligence de chaque homme", to należy poszerzyć ten zakres do sfery pogłębionego poznania.

${ }^{179}$ C.G. Le Roy, Instinct, w: Encyclopédie ou dictionnaire universel, dz. cyt., t. 8, 795-799.

180 „Vérité éternelle, (Logiq. Métaphysiq. Morale.) c'est une proposition générale \& certaine, qui dépend de la convenance, ou de la disconvenance qui se rencontre dans des idées abstraites", stąd w sposób charakterystyczny dla Pascala czy Reida prawdy wieczne odnosi chevalier Louis de Jacourt do przekonania ludzkości o istnieniu Boga: „Ainsi ayant l'idée de Dieu \& de moi-même, celle de crainte \& d'obéissance; cette proposition: les hommes doivent craindre Dieu \& lui obéir, est une vérité éternelle, parce qu'elle est véritable à l'égard de tous les hommes qui ont existé, qui existent, ou qui existeront”. L. de Jacourt (sygnowany jako „D.J”), Vérité éternelle, w: Encyclopédie ou dictionnaire universel, dz. cyt., t. 17, 71.

181 „Bon-sens, s. m. (Métaphysique.) c'est la mesure de jugement \& d'intelligence avec laquelle tout homme est en état de se tirer à son avantage des affaires ordinaires de la société. Otez à l'homme le bon-sens, \& vous le réduirez à la qualité d'automate ou d'enfant. Il me semble qu'on exige plûtôt dans les enfans de l'esprit que du bon-sens; ce qui me fait croire que le bon-sens suppose de l'expérience, \& que c'est de la faculté de déduire des expériences, qu'on fait le plus communément les inductions les plus immédiates. Il y a bien de la différence dans notre langue entre un homme de sens \& un homme de bon-sens: l'homme de sens a de la profondeur dans les connoissance, $\&$ beaucoup d'exactitude dans le jugement; c'est un titre dont tout homme peut être flatté: l'homme de bon-sens au contraire passe pour un homme si ordinaire, qu'on croit pouvoir se donner pour tel sans vanité. Au reste il n'y a rien de plus relatif que les termes sens, sens-commun, bon-sens, esprit, jugement, pénétration, sagacité, génie, \& tous les autres termes qui marquent soit l'étendue, soit la sorte d'intelligence de chaque homme. On donne ou l'on accorde ces qualités, selon qu'on les mérite plus ou moins soi-même". [anonimowo] Bon-sens, w: Encyclopédie ou dictionnaire universel, dz. cyt., t. 2, 328-329. 


\section{PODSUMOWANIE}

Wydaje się, że przeprowadzone rozważania ukazały integralność ludzkiej wiedzy, postulowanej przez Błażeja Pascala. Winna zespalać ona, z jednej strony, rozum, pojęty w sensie operacji dyskursywnej, $\mathrm{z}$ intuicją i instynktem, a z drugiej - poznanie naturalne z wiarą. Pascal wychodzi poza zestaw prawd dostępnych w poznaniu ugruntowanym na dyskursie (raison). Szczególną rolę wyznaczał intuicji określanej w kategoriach sentir czy nawet instinct, operując takimi kategoriami jak esprit de finesse, utożsamiany z sens droit czy esprit de justesse, istotnymi wręcz w odniesieniu do poznania principes. Równocześnie tak pojęte wyposażenie ludzkiego umysłu (lumière naturelle) odpowiada aspektywnie wiedzy ugruntowanej na cour, przeciwstawianej interpretowanemu racjonalistycznie raison, gdy na gruncie religii lumière naturelle jest komplementarne wobec inspiration czy révélation.

Podejście to, opozycyjne wobec przejawów naturalistycznie pojętego racjonalizmu, wydaje się wpisywać w długi ciąg filozofii zdrowego rozsądku liczącej się z realiami ludzkiej natury. Sięga ona myśli Arystotelesa, mimo nowożytnej kontestacji jego nauki. Punktem odniesienia rozważań Pascala nade wszystko jest jednak epistemologia Kartezjusza podkreślającego znaczenie apriorycznych elementów poznania, traktowanych jako naturalne wyposażenie ludzkiego umysłu, do których odwołuje się intuicja czy instynkt. Konsekwencją integralności poznania jest akceptacja maksymalistycznie pojętej filozofii, nawet jeśli w nowożytności zmienił się paradygmat - z metafizycznego na epistemologiczny. Traktowanie ówczesnych ograniczeń w zakresie wykładu metafizyki jako przejawu minimalizmu, a nawet swoistego agnostycyzmu, nie wydaje się jednak uprawnione dlatego, że ze względu na zmianę nowożytnego paradygmatu, to epistemologia była głównym terenem, na którym rozgrywały się podstawowe spory filozoficzne. Owocowały one określonymi rozstrzygnięciami światopoglądowymi, istotnymi w perspektywie ówczesnej dominacji kultury religijnej. Być może nawet, że to właśnie religijne milieu wymuszało podjęcie wątków metafizycznych, które stanowiłyby fundament światopoglądu religijnego. W tym kontekście wymóg ten aktualizowało ówczesne szkolnictwo, preferując u schyłku wieku oświecenia szkocką filozofię zdrowego 
rozsądku, broniącą integralności ludzkiej wiedzy wobec przejawów filozoficznego minimalizmu, a nawet swoistego sceptycyzmu, groźnego dla ładu kulturowego.

\section{BIBLIOGRAFIA}

Aaron R.I., John Locke, Clarendon Press, Oxford $1955^{2}$.

Adams R.W., The Locke-Leibniz Debate, w: Innate Ideas, red. S.P. Stich, University of California Press, Berkeley 1975, 37-57.

Adams R.W., Where Do Our Ideas Come From? Descartes vs. Locke, w: Innate Ideas, red. S.P. Stich, University of California Press, Berkeley 1975, 71-87.

Alembert J. le Rond d', Discours préliminaire de l'Encyclopedie, w: Euvres complètes de d'Alembert, red. A. Belin, t. 1-5, Paris 18211822; repr. Slatkine, Genève 1967, t. 1, 13-99; toż, jako: Wstęp do Encyklopedii, tłum. z franc. J. Hartwig, Państwowe Wydawnictwo Naukowe, Warszawa 1954.

Alembert J. le Rond d', Essai sur les élements de philosophie, ou sur les principes des connaissances humaines, w: Mélanges de littérature, d'histoire et de philosophie, t. 4, Amsterdam 1759; toż w: Euvres complètes de d'Alembert, Euvres complètes de d'Alembert, red. A. Belin, t. 1-5, Paris 1821-1822; repr. Slatkine, Genève 1967, t. 1, 115-348. Alexander P., Locke on Substance-in-General, Ratio 22(1980), 91-105; 23(1981), 1-19.

Amesbury R., Fideism, w: The Stanford Encyclopedia of Philosophy (Winter 2012 Edition), red. E.N. Zalta, http://plato.stanford.edu/ entries/fideism/.

Arnauld A., Nicole P., La logique, ou l'art de penser contenant, outre les règles communes, plusieurs observations nouvelle propres à former le jugement, par le Sieur le Bon (Paris 1662; przedr. wydania z roku 1638 - Olms, Hildesheim 1970; toż jako: Logika, czyli sztuka myślenia, tłum. z franc. S. Rohmanowa, Państwowe Wydawnictwo Naukowe, Warszawa 1958).

Arndt H.W., Methodo scientifica pertractatum. Mos geometricus und Kalkülbegriff in der philosophischen Theorienbildung des 17. und 18. Jahrhunderts, De Gruyter, Berlin 1971. 
Ayers M.R., The Ideas of Power and Substance in Locke's Philosophy, Philosophical Quarterly 25(1975), 1-27.

Ben-Chaim M., Locke's Ideology of „,Common Sense”, Studies in History and Philosophy of Science 31(2000)3, 473-501.

Bargieł F., Stanisław Szadurski SJ (1726-1789). Przedstawiciel uwspótcześnionej filozofii scholastycznej, Wydział Filozoficzny Towarzystwa Jezusowego, Kraków 1978.

Beck L.J., The Method of Descartes. A Study of the Regulae, Clarendon Press, Oxford 1952.

Benedykt XVI, Mój umiłowany Poprzednik, tłum. z wł. R. Łobko, Świat Książki, Częstochowa 2007.

Benedykt XVI, Wróćmy do filozofii, by lepiej zrozumieć wspótczesność. Do uczestników VI Europejskiego Sympozjum Nauczycieli Akademickich (7 VI 2008), L’Osservatore Romano 29(2008), wydanie polskie, 10(2008)7-8, 21.

Bermúdez J.L., Locke. Metaphysical Dualism and Property Dualism, British Journal for the History of Philosophy 4(1996), 223-245.

Bocheński J.M., Spitzfindigkeit, w: Hommage aux catholiques suisses (Festgabe an die Schweizer Katholiken), Fribourg 1954, 334-352; toż jako: Subtelność, w: Tenże, Logika i filozofia. Wybór pism, tłum. z niem. D. Gabler, Wydawnictwo Naukowe PWN, Warszawa 1993. Boitano J.F., Polemics of Libertine Conversion in Pascal's „Pensées”, Narr, Tübingen 2002.

Bolton M.B., Substances, Substrata, and Names of Substances in Locke's „Essay”, w: Locke, red. V. Chappell, Oxford 1998, 86-105.

Bolton M.B., Substratum, w: Locke, red. V. Chappell, Oxford 1998, 129-148.

Bon-sens, w: Encyclopédie ou dictionnaire universel, Encyclopédie ou dictionnaire universel raisonné des sciences, des arts et des métiers, par une société de gens de lettres. Mis en ordre et publié par... [Denis] Diderot et quant à la partie mathématique par...... [Jean le Rond] D'Alembert, t. 2, 328-329.

Brandt R., John Locke, w: Die Philosophie des 17. Jahrhunderts, t. 3. red. J.-P. Schobinger, Schwabe, Basel 1988, 624, 626.

Bréhier E., La Creation des vérités éternèlles dans le système de Descartes, Revue de Philosophie de la France et de l'Etranger 62(1937), 16-29. 
Buffier C., Cours de sciences sur des principes nouveaux et simples, pour former la langage, l'esprit et le cour dans l'usage ordinaire de la vie, Paris 1732; repr. Cours de sciences. Sur des principes nouveaux et simples pour former le langage, l'esprit et le cœur, dans l'usage ordinaire de la vie, suivi de Homère en arbitrage, Slatkine, Genève 1971. Buttler J., The Analogy of Religion, Natural and Revealed, to the Constitution and Course of Nature, London 1736; toż jako: The Analogy of Religion, red. E.C. Mossner, F. Ungar, New York 1961.

Chateaubriand R., Le Génie du christianisme, t. 1-2, Furne, Paris 1864 1866; toż jako: Geniusz chrześcijaństwa, tłum. z franc. A. Loba, Poznań 2003.

Chaunu P., Cywilizacja wieku Oświecenia, tłum. z franc. E. Bąkowska, Państwowy Instytut Wydawniczy, Warszawa 1993.

Chlewiński Z., Fideizm, w: Powszechna encyklopedia filozofii, t. 3, red. A. Maryniarczyk i in., Towarzystwo Naukowe KUL, Lublin 2002, 427-428.

Chudy W., Hegla metafizyka pojęcia absolutnego, w: Metafizyka w filozofii [seria: Zadania wspótczesnej metafizyki, nr 6], red. A. Maryniarczyk, K. Stępień, Polskie Towarzystwo Tomasza z Akwinu, Lublin 2004, 321-373.

Condillac É., De l'art de raisonner, w: Cours d'études pour l'instruction du prince de Parme, t. 13, Parma [właśc. Paris] 1775 ; toż w: Cuvres philosophiques de Condillac, t. 1, red. G. Le Roy, Presses universitaires de France, Paris 1947, 619-714.

Condillac É., La Logique ou les premiers développements de l'art de penser, Paris 1780; toż w: Cuvres philosophiques de Condillac, t. 2, red. G. Le Roy, Presses universitaires de France, Paris 1948, 371-416; toż jako: Logika czyli pierwsze zasady sztuki myślenia, dzieło elementarne... na żądanie bywszej Komisji Edukacyjnej Narodowej dla szkót publicznych napisane i od niej aprobowane, a teraz z przydatkiem niektórych objaśnień i przypisów przez Jana Znoskę z francuskiego na polski język przetożone, Wilno 1802, 18193; toż jako: Logika, red. T. Kotarbiński, Warszawa 1952.

Condillac É., Traité des animaux, w: Euvres philosophiques de Condillac, t. 1, red. G. Le Roy, Presses universitaires de France, Paris 1947, 337-379. 
Cranston M., John Locke. A Biography, Longmans, London 1957.

Cudworth R., The True Intellectual System of the Universe, Printed for Richard Royston, London 1678.

Curley E., Descartes on the Creation of the Eternal Truths, Philosophical Review 93(1984), 569-597.

Czarnawska M., Czy idea jest ajdosem, Studia Filozoficzne 29(1985)8-9, 163-167.

Dadaczyński J., Filozofia matematyki, Biblos, Tarnów 2000.

Daniel S.H., Descartes' Treatment of 'lumen naturale', Studia Leibnitiana 10(1978)1, 92-100.

Davidson H.M., The Origins of Certainty. Means and Meanings in Pascal's Pensées, University of Chicago Press, Chicago 1979.

Descartes R., Descartes a Elisabeth, w: Euvres de Descartes, wyd. Ch. Adam, P. Tannery, Vrin, Paris 1897-1913, t. 3, 663-668; toż jako: Listy do księżniczki Elżbiety, tłum. z franc. J. Kopania, Wydawnictwo PWN, Warszawa 1995.

Descartes R., Discours de la méthode pour bien conduire sa raison et chercher la verité dans les sciences. Leyde 1637; toż w wyd. É. Gilson jako: Discours de la Méthode. Texte et commentaire, Paris 1925; toż jako: Discours de la méthode, w: Euvres de Descartes, wyd. Ch. Adam, P. Tannery, Paris 1897-1913; repr. Vrin, Paris 1996, t. 6; toż jako: Rozprawa o metodzie wtaściwego kierowania rozumem i poszukiwania prawdy w naukach, tłum. z franc, W. Wojciechowska, Kraków 1950, Państwowe Wydawnictwo Naukowe, Warszawa 19883, Descartes R., Les Principes de la philosophie, tłum. z franc. C. Picot, Paris 1647; toż w: Euvres de Descartes, wyd. Ch. Adam, P. Tannery, Vrin, Paris 1897-1913, t. 9.

Descartes R., Meditationes de prima philosophia. Parisiis 1641; toż w: Euvres de Descartes, wyd. Ch. Adam, P. Tannery, Vrin, Paris 1897-1913, t. 7, 1-353; toż jako: Medytacje o pierwszej filozofii wraz z zarzutami uczonych mężów i odpowiedziami autora oraz rozmowa z Burmanem, t. 1-2, tłum. z franc. M. i K. Ajdukiewiczowie, S. Swieżawski, I. Dąmbska, Warszawa 1958, Kęty 2001.

Descartes R., Principia philosophiae, Amstelodamii 1644; toż w: CEuvres de Descartes, t. 8, 1-353; toż jako: Zasady filozofii, tłum. z łac. I. Dąmbska, Państwowe Wydawnictwo Naukowe, Warszawa 1960. 
Descartes R., Regulae ad directionem ingenii, Amstelodamii 1701; toż w: Euvres de Descartes, wyd. Ch. Adam, P. Tannery, Vrin, Paris 1897-1913, t. 10, 349-469; toż jako, Prawidła kierowania umysłem, w: Tenże, Prawidła kierowania umystem. Poszukiwanie prawdy poprzez światło przyrodzone rozumu, tłum. z łac. L. Chmaj, Państwowe Wydawnictwo Naukowe, Warszawa 1958², 1-114.

Drozdowicz Z., Antynomie Pascala, SAWW, Poznań 1993.

Drozdowicz Z., Blaise Pascal versus Descartes, w: Tradycja a wspótczesność, red. R. Kozłowski, Wydawnictwo Naukowe Uniwersytetu im. Adama Mickiewicza, Poznań 1981, 43-52.

Drozdowicz Z., Kartezjusz a współczesność, Wydawnictwo Naukowe Uniwersytetu im. Adama Mickiewicza, Poznań 1980.

Drozdowicz Z., O racjonalności w filozofii nowożytnej. Wykłady, Wydawnictwo Naukowe Uniwersytetu im. Adama Mickiewicza, Poznań 2008. Drozdowicz Z., Pascalowska koncepcja geometrycznego sposobu myślenia, w: Idee a rzeczywistość, red. S. Kaczmarek, Wydawnictwo Naukowe Uniwersytetu im. Adama Mickiewicza, Poznań 1980, 73-82.

Du Marsais C.Ch., Éducation, w: Encyclopédie ou dictionnaire universel raisonné des sciences, des arts et des métiers, par une société de gens de lettres. Mis en ordre et publié par... [Denis] Diderot et quant à la partie mathématique par..... [Jean le Rond] D'Alembert, t. 1-35, Paris 1751-1780; repr. F. Frommann Verlag, Stuttgart 1966-1995, t. 5, 397-340.

Dzidek T., Granice rozumu w teologicznym poznaniu Boga, Wydawnictwo M, Kraków 2001.

Force P., Pascal and Philosophica method, w: The Cambridge Companion to Pascal, Cambridge University Press: Cambridge 2003, 216-234.

Frankfurt H.G., Descartes on the Creation of the Eternal Truths, Philosophical Review 86(1977), 36-57.

Gaukroger S., Cartesian Logic. An Essay on Descartes's Conception of Inference, Clarendon Press, Oxford 1989.

Gewirth A., Clearness and Distinctness in Descartes, w: Descartes, red. J. Cottingham, Oxford University Press, Oxford 1998, 79-100. 
Głąb A., Kartezjańska koncepcja zjednoczenia umystu i ciała - na podstawie interpretacji Margaret D. Wilson, Roczniki Filozoficzne 58(2010)1, 27-50.

Goldmann L., Le Dieu caché, Gallimard, Paris 1955.

Greenlee D., Locke and the Controversy over Innate Ideas, Journal of the History of Ideas 33(1972), 251-264.

Gregory S., Lumen naturale Licht und Wahrheit bei Descartes, Zeitschrift für Kulturphilosophie 8(2014)2, 261-278.

Grosholz E.R., Cartesian Method and the Problem of Reduction, Clarendon Press, Oxford 1991.

Gutowski P., O trzech elementach filozofii Thomasa Reida, Roczniki Filozoficzne 58(2010)1, 71-93.

Hankinson R.J., Science, w: The Cambridge Companion to Aristotle, red.

J. Barnes, Cambridge University Press, Cambridge 1995, 140-167.

Harrington T.M., Vérité et méthode dans les Pensées de Pascal, Vrin, Paris 1972.

Harris J., Leibniz and Locke on Innate Ideas, Ratio 16(1974), 226-242. Heller M., Filozofia świata. Wybrane zagadnienia i kierunki filozofii przyrody, Społeczny Instytut Wydawniczy Znak, Kraków 1992.

Heller M., Pascal - uczony niekonwencjonalny, Zagadnienia Filozoficzne w Nauce 36(2005), 156-159.

Hempoliński M., U źródeł filozofii zdrowego rozsadku. Thomasa Reida teoria spostrzeżenia zmysłowego, Państwowe Wydawnictwo Naukowe, Warszawa 1966.

Herbert of Cherbury E., De veritate, prout distinguitur a revelatione, a verisimili, a possibili, et a falso, Parisiis 1624.

Hertling G. von, John Locke und die Schule von Cambridge, Freiburg im Breisgau, Herder, 1892.

Jacourt L. de, Science (Logiq. \& Métaphys.), w: Encyclopédie ou dictionnaire universel raisonné des sciences, des arts et des métiers, par une société de gens de lettres. Mis en ordre et publié par... [Denis] Diderot et quant à la partie mathématique par..... [Jean le Rond] D'Alembert, t. 1-35, Paris 1751-1780; repr. F. Frommann Verlag, Stuttgart 1966-1995, t. 14, 787-793.

Jacourt L. de, Vérité éternelle, w: Encyclopédie ou dictionnaire universel raisonné des sciences, des arts et des métiers, par une société de gens 
de lettres. Mis en ordre et publié par... [Denis] Diderot et quant à la partie mathématique par...... [Jean le Rond] D'Alembert, t. 1-35, Paris 1751-1780; repr. F. Frommann Verlag, Stuttgart 1966-1995, t. 17, 71. Jacquette D., Descartes' Lumen Naturale and the Cartesian Circle, Philosophy and Theology: Marquette University Quarterly, 9(1996), 273-320.

Janeczek S., Dydaktyka logiki w szkołach KEN a koncepcja logiki w „Wielkiej Encyklopedii Francuskiej”, Rocznik Historii Filozofii Polskiej 4/5(2011/2012), 105-134.

Janeczek S., Filozofia Boga w okresie oświecenia, Zeszyty Naukowe KUL 32(1989)1-4(125-128), 29-48.

Janeczek S., Geneza nowożytnego arystotelizmu chrześcijańskiego, w: Oblicza filozofii XVII wieku, red. S. Janeczek, Wydawnictwo KUL, Lublin 2008, 477-512.

Janeczek S., Kartezjanizm teorii nauki É. Condillaca, w: Filozofia XVII wieku i jej kontynuacje, red. Z. Drozdowicz, Wydawnictwo Fundacji Humaniora, Poznań 2009, 203-209.

Janeczek S., Koncepcja ,filozofii chrześcijańskiej” w pismach polskich pijarów w okresie oświecenia. Uwagi metodologiczno-historyczne, Roczniki Filozoficzne 41(1993)1, 125-155.

Janeczek S., Koncepcja logiki w „Wielkiej Encyklopedii Francuskiej”. Studium z historii recepcji, Studia Philosophiae Christianae 46(2010)2, 5-24.

Janeczek S., Logika czy epistemologia? Historycznofilozoficzne uwarunkowania nowożytnej koncepcji logiki, Wydawnictwo KUL, Lublin 2003.

Janeczek S., O trudnościach kategorializacyjnych w historii nowożytnej teorii nauki. Opozycja: racjonalizm - empiryzm, w: Leibniz. Tradycja i idee nowoczesnej filozofii, red. B. Paź, Wydawnictwo Aureus, Kraków 2010, 135-151.

Janeczek S., Prepozytywizm filozofii Jean le Rond d'Alemberta?, Zeszyty Naukowe KUL 55(2012)2(218), 3-24.

Janeczek S., Racjonalizm kultury intelektualnej Johna Locke'a, Roczniki Kulturoznawcze 2(2011), 51-70.

Janeczek S., Teoria nauki w ujęciu J. le Ronda d'Alemberta. Między empiryzmem, racjonalizmem i intuicjonizmem, w: Philosophia vitam 
alere. Prace dedykowane Profesorowi Romanowi Darowskiemu SJ, Ignatianum - WAM, Kraków 2005, 199-212.

Janeczek S., Z dziejów dydaktyki logiki w szkołach KEN. Claude Buffier SJ, Roczniki Filozoficzne 56(2008)2, 83-99.

Janeczek S., Z dziejów genezy nowożytnej filozofii religii. Kartezjusz, w: Abiit, non obiit. Księga poświęcona pamięci Księdza Profesora Antoniego Kościa SVD, red. A. Dębiński i in., Wydawnictwo KUL, Lublin 2013, 575-587.

Janeczek S., Z dziejów kultury naukowej. Koncepcja nauki Jean le Rond d'Alemberta, Roczniki Kulturoznawcze 4(2013)1, 59-92.

Jan Paweł II, Fides et ratio. Tekst i komentarze, red. T. Styczeń, W. Chudy, Wydawnictwo KUL, Lublin 2003.

Jeffreys M.V.C., John Locke. Prophet of Common Sense, Methuen, London 1967.

Jung-Palczewska E., Między filozofia przyrody a nowożytnym przyrodoznawstwem. Ryszard Kilvington i fizyka matematyczna wśredniowieczu, Wydawnictwo Uniwersytetu Łódzkiego, Łódź 2002.

Jung-Palczewska E., Procedura secundum imaginationem w czternastowiecznej filozofii przyrody, w: Księga pamiątkowa ku czci Profesora Zdzisława Kuksewicza, red. E. Jung-Palczewska, Wydawnictwo Uniwersytetu Łódzkiego, Łódź 2000, 57-79.

Kamiński S., Dedukcja w metafizyce scholastycznej, w: M.A. Krąpiec, S. Kamiński, Z teorii i metodologii metafizyki, Towarzystwo Naukowe KUL, Lublin 1994³, 346-344.

Kamiński S., Koncepcja nauki u Arystotelesa, Zagadnienia Naukoznawstwa 16(1980), 11-17; toż w: Tenże, Metoda i język, Towarzystwo Naukowe KUL, Lublin 1994, 247-254.

Kenny A., The Cartesian Circle and the Eternal Truths, Journal of Philosophy 67(1970), 685-700.

Knight I.F., The Geometric Spirit. The Abbé de Condillac and the French Enlightenment, Yale University Press, New Haven 1968.

Koch E.R., Pascal and Rhetoric. Figural and Persuasive Language in the Scientific Treatises, the „Provinciales”, and the „Pensees”, Rookwood Press, Charlottesville 1997.

Kopania J., Funkcje poznawcze Descartesa teorii idei, Dział Wydawnictw Filii UW w Białymstoku, Białystok 1988. 
Krąpiec M.A., Elementy filozofii poznania, w: M.A. Krąpiec i in., Wprowadzenie do filozofii, Redakcja Wydawnictw KUL, Lublin 1992.

Krąpiec M.A., Realizm ludzkiego poznania, Redakcja Wydawnictw KUL, Lublin $1995^{2}$.

T. Kubalica, John Locke i George Berkeley wobec problemu istoty poznania, Idea - Studia nad strukturą i rozwojem pojęć filozoficznych 24(2012), 37-58.

Kuehn M., Scottish Common Sense in Germany, 1768-1800. A Contribution to the History of Critical Philosophy, McGill University, Kingston 1987.

Laporte J., La Cour et la raison selon Pascal, Reveue philosophique de la France et de l'Etranger 103(1927), 98-118, 225-299, 421-451; toż jako druk samoistny: Elzévir, Paris 1950.

Le Roy C.G., Instinct, w: Encyclopédie ou dictionnaire universel, Encyclopédie ou dictionnaire universel raisonné des sciences, des arts et des métiers, par une société de gens de lettres. Mis en ordre et publié par... [Denis] Diderot et quant à la partie mathématique par... [Jean le Rond] D'Alembert, t. 1-35, Paris 1751-1780; repr. F. Frommann Verlag, Stuttgart 1966-1995, t. 8, 795-799.

Lewin P., Teoria akuminu w estetycznej świadomości wschodniej słowiańszczyzny XVII-XVIII wieku a traktat Sarbiewskiego, w: Literatura staropolska i jej zwiazki europejskie, red. J. Pelc, Zakład Narodowy imienia Ossolinskich, Wrocław 1973, 309-322.

Locke J., An Essay Concerning Human Understanding, London 1690, właściwe 1689; toż w: The Works of John Locke, London 182333; repr. Scientia Verlag, Aalen 1963; toż jako Rozważania dotyczace rozumu ludzkiego, tłum. z ang. B. Gawecki, t. 1-2, Państwowe Wydawnictwo Naukowe,Warszawa 1955.

Logique, w: Encyclopédie ou dictionnaire universel raisonné des sciences, des arts et des métiers, par une société de gens de lettres. Mis en ordre et publié par... [Denis] Diderot et quant à la partie mathématique par... [Jean le Rond] D'Alembert, t. 1-35, Paris 1751-1780; repr. F. Frommann Verlag, Stuttgart 1966-1995, t. 9, 637-641. Lubańska S., Sceptycyzm Pascala, Filo-Sofia 7(2012)2, 75-82. 
Mackie J.L., Locke and Representative Perception, w: Logic and Knowledge. Selected Papers, t. 1, red. J.L. Mackie, Clarendon Press, Oxford 1985, 214-224.

Marcil-Lacoste L., Claude Buffier and Thomas Reid. Two Common-Sense Philosophers, McGill-Queen's University Press, Kingston 1982.

Marciszewski W., Logic from a Rhetorical Point of View, De Gruyter, Berlin 1994.

Marion J.-L., Cartesian Metaphysics and the Role of the Simple Natures, w: The Cambridge Companion to Descartes, red. J. Cottingham, Cambridge University Press, Cambridge 1992, 115-139.

McCann R., Locke's Philosophy of Body, w: The Cambridge Companion to Locke, red. V. Chappell, Cambridge University Press, Cambridge 1999, 56-88.

Méthodes chez Pascal. Actes du colloque tenu à Clermont-Ferrand 10-13 juin 1976, red. J. Mesnard, Presses Universitaires de France, Paris 1979.

Milton J.R., Laws of Nature, w: The Cambridge History of Seventeenth-Century Philosophy, t. 1, red. D. Garber, M. Ayers, Cambridge University Press, Cambridge 1998, 686-687.

Morawiec E., Przedmiot a metoda $w$ filozofii Kartezjusza, Akademia Teologii Katolickiej, Warszawa 1970.

More H., Opera omnia, J. Martyn et G. Kettilby, Londini 1679.

Morris J., Descartes' Natural Light, Journal of the History of Philosophy 11(1973)2, 169-187.

Neemann U., Gegensätze und Syntheseversuche im Methodenstreit der Neuzeit, t. 1-2, Olms Verlag, Hildesheim 1993-1994.

Nichols R., Yaffe G., Thomas Reid, w: The Stanford Encyclopedia of Philosophy, http://plato.stanford.edu/entries/reid/.

Nichols R., Callergård R., Thomas Reid on Reidian Religious Belief Forming Faculties, Modern Schoolman 88(2011), 317-335.

Norman B., Portraits of Thought, Knowledge, Methods and Styles in Pascal, Ohio State University Press, Columbus 1988.

Nowak L., Arystotelesowska teoria nauki, Studia Philosophiae Christianae 12(1976)1, 136-168.

Nuchelmans G., Judgment and Proposition. From Descartes to Kant, Amsterdam 1983. 
Odczytywanie myśli Pascala, red. A. Siemianowski, Wydawnictwo Fundacji Humaniora, Poznań 1997.

Ogonowski Z., Locke, Książka i Wiedza, Warszawa 1972.

O’Neil B.E., Epistemological Direct Realism in Descartes' Philosophy, University of New Mexico Press, Albuquerque 1974.

Pailin D.A., Herbert von Cherbury, w: Die Philosophie des 17. Jahrhunderts, t. 3. red. J.-P. Schobinger, Schwabe, Basel 1988, 224-239, 284-285.

Parker Th., Volition, Rhetoric, and Emotion in the Work of Pascal, Routledge, New York 2008.

Pascal B., De l'art de persuader, w: P.-N. Desmolets, Continuation des Mémoires de littérature et d'histoire, t. 5/2, Paris 1728, 271-296; De l'esprit de la géométrie, w: P.-N. Desmolets, Continuation des Mémoires, dz. cyt., 302-331; pełne wydanie wraz z pełniejszym wydaniem Pensées, wyd. A. de Condorcet, Paris 1776; całość w: L'Esprit de la géométrie et De l'art de persuader, w: B. Pascal, Euvres complètes, Librarire Gallimard, Paris 1954, 575-604; toż jako: Rozważania ogólne nad geometria. O geometrycznym sposobie myślenia i o sztuce przekonywania, w: B. Pascal, Rozprawy i listy, tłum. z franc. M. Tazbir, Instytut Wydawniczy Pax, Warszawa 1962, 113-156.

Pascal B., Pensées de M. Pascal sur la religion et surquelques autres sujets, Paris 1670; cyt. jako Pensées, wyd. J. Chevalier, w: B. Pascal, Euvres complètes, Librarire Gallimard, Paris 1954, 1081-1345; toż jako: Myśli, tłum. z franc. T. Żeleński-Boy, Instytut Wydawniczy Pax, Warszawa 1972.

Pelletier F.J., Locke's Doctrine of Substance, Canadian Journal of Philosophy (suppl.) 4(1978), 121-140.

Płużański T., Pascal, Wiedza Powszechna, Warszawa 1974.

Przepis Komisji Edukacji Narodowej na szkoty wojewódzkie, w: Ustawodawstwo szkolne za czasów Komisji Edukacji Narodowej. Rozporządzenia, ustawy pedagogiczne i organizacyjne (1773-1793), wyd. J. Lewicki, M. Arct, Kraków 1925.

Ratzinger J., Europa Benedykta w kryzysie kultur, tłum. z niem. W. Dzierża, Święty Paweł, Częstochowa 2005.

Ratzinger J., Wiara - prawda - tolerancja. Chrześcijaństwo a religie świata, tłum. z niem. R. Zajączkowski, Jedność, Kielce 2004. 
Ratzinger J., Wykłady bawarskie z lat 1963-2004, tłum. z niem. A. Czarnocki, Instytut Wydawniczy Pax, Warszawa 2009.

Raube S., Deus explicatus. Stworzenie i Bóg w myśli Ralpha Cudwortha, Wydawnictwo Uniwersytetu w Białymstoku, Białystok 2000.

Raube S., Metafizyka i etyka Samuela Clarke'a, Wydawnictwo Uniwersytetu w Białymstoku, Białystok 2010.

Reid Th., Essays on the Intellectual Powers of Man, Edinburgh 1875; repr. Scolar Press, Menston 1971; toż jako: Rozważania o władzach poznawczych człowieka, tłum. z ang. M. Hempoliński, Państwowe Wydawnictwo Naukowe, Warszawa 1975.

Rembierz M., Rozum otwarty i jego wrogowie? Logos i rozum w argumentacji Josepha Ratzingera (Benedykta XVI), w: W kręu teologii Josepha Ratzingera - Benedykta XVI, red. K. Wolsza, Redakcja Wydawnictw Wydziału Teologicznego Uniwersytetu Opolskiego, Opole 2008, 203-230.

Rieger H.-M., Menschlich denken - Glauben begründen. Blaise Pascal und religionsphilosophische Begründungsmodelle der Moderne, De Gruyter, Berlin 2011.

Risse W., Die Logik der Neuzeit, t. 2: 1640-1780, Frommann, Stuttgart 1970.

Rogers G.A.J., Die Cambridger Platoniker, w: Die Philosophie des 17. Jahrhunderts, t. 3. red. J.-P. Schobinger, Schwabe, Basel 1988, 240-290.

Rogers G.A.J., Locke, Newton, and the Cambridge Platonists on Innate Ideas, Journal of the History of Ideas 40(1979), 191-205.

Rohmanowa S., Wstep, w: A. Arnauld, P. Nicole, Logika, czyli sztuka myślenia, tłum z franc. S. Rohmanowa, Państwowe Wydawnictwo Naukowe, Warszawa 1958, XI-XXVI.

Roskal Z.E., Astronomia matematyczna $w$ nauce greckiej, Wydawnictwo KUL, Lublin 2002.

Rousseau J.J., Économie ou Economie, w: Encyclopédie ou dictionnaire universel raisonné des sciences, des arts et des métiers, par une société de gens de lettres. Mis en ordre et publié par... [Denis] Diderot et quant à la partie mathématique par... [Jean le Rond] D'Alembert, t. 1-35, Paris 1751-1780; repr. F. Frommann Verlag, Stuttgart 1966-1995, t. 5, 337-349. 
Rozum otwarty na wiare. ,„ Fides et ratio« - w rocznice ogłoszenia”. II Międzynarodowe Sympozjum Metafizyczne (KUL, 9-10.XII.1999), red. A. Maryniarczyk, A. Gudaniec, Polskie Towarzystwo Tomasza z Akwinu, Lublin 2000.

Schmidt W., Intuition und Deduktion. Untersuchungen zur Grundlegung der Philosophie bei Spinoza, w: K. Peters, W. Schmidt, H.H. Holz, Erkenntnisgewißheit und Deduktion. Zum Aufbau der philosophischen Systeme bei Descartes, Spinoza, Leibniz, Luchterhand, Darmstadt 1975, 57-128.

Sady W., Dlaczego „Rozmowy i dowodzenia matematyczne” Galileusza sa naukowe, a „Świat” Kartezjusza nie?, w: Pogranicza nauki. Protonauka-paranauka-pseudonauka, red. J. Zon, Wydawnictwo KUL, Lublin 2009, 87-100.

Salamon G., Mathematical Roots of Cartesian Metaphysics, The New Scolastiscism 39(1965), 158-169.

Sardemann F.H., Ursprung und Entwicklung Der Lehre von Lumen Rationis Aeternae, Lumen Divinum, Lumen Naturale, Rationes Seminales, Veritates Aeternae bis Descartes, Röttger, Kassel 1902.

Schober A., D'Alembert de vermeintliche Vater des Positivismus. Eine historisch-systematische Untersuchung, Univ., Diss., Erlangen 1982. Scholz K., Abriss der Geschichte der Logik, Freiburg 1959, 1967²; toż jako: Zarys historii logiki, tłum. z niem. M. Kurecka-Wirpszowa, Państwowe Wydawnictwo Naukowe, Warszawa 1965.

Schuster J.A., Cartesian Method as Mythic Speech. A Diachronic and Structural Analysis, w: The Politics and Rhetoric of Scientific Method. Historical Studies, red. J.A. Schuster, R.R. Yeo, Reidel, Dordrecht 1986.

Shea W.R., Designing Experiments and Games of Chance - The Unconventional Science of Blaise Pascal, Science History Publications/ USA, Cantonn, MA, 2003.

Spinoza B., Renati Des Cartes Principiorum philosophiae pars I et II more geometrico domonstratae, Amstolodami 1663; toż w: Tenże, Opera, wyd. C. Gebhardt, t. 1, Winter, Heildelberg 1925.

Starzyński W., Kartezjańskie motywy filozofii oczywistości. Analiza hasła „Evidence” Wielkiej Encyklopedii Francuskiej autorstwa 
François Quesnaya, Archiwum Historii Filozofii i Myśli Społecznej 53(2008), 65-92.

Stegliński T., Pierre Chanet, polemista i filozof instynktu, oraz Marin Cureau de la Chambre - historia pewnego sporu, Roczniki Filozoficzne 63(2015), 65-84.

Stewart M.A., The curriculum in Britain, Ireland end the Colonies, w: The Cambridge History of Eighteenth-Century Philosophy, t. 1, red. K. Haakonssen, Cambridge University Press, Cambridge 2011,97-120. Strasser J., „Lumen naturale, Sens commun, Common sense”. Zur Prinzipienlehre Descartes', Buffiers i Reids, Zeitschrift für Philosophie Forschung 23(1969)2, 178-189.

Substanz. Neue Überlegungen zu einer klassischen Kategorie des Seienden, red. K. Trettin, Klostermann, Frankfurt am Main 2005.

Sutton T. J., The Scottish Kant? A Reassessment of Reid's epistemology, $\mathrm{w}$ : The Philosophy of Thomas Reid, red. M. Dalgarno, E. Matthews, Kluwer Academic Publishers, Dordrecht 1989, 159-192.

Szałek P.K., Zagadnienie sceptycyzmu w kontekście wpływu myśli Locke'a na filozofię Berkeleya, Roczniki Filozoficzne 58(2010)1, 229-246.

Szymik J., „Logos” $i$ „,ratio”. J. Ratzingera/Benedykta XVI opowieść o Bogu, który obdarza łaska rozumu i łaska wiary, Teologia w Polsce 6(2012)1, 5-19.

Śliwiński T., Ratio et physis. Fizyka teoretyczna Kartezjusza jako realizacja projektu mathesis universalis, Wydawnictwo Rolewski, Nowa Wieś 2005.

Tatarkiewicz W., O niektórych postaciach racjonalizmu XVII i XVIII wieku, w: Księga pamiatkowa Drugiego Polskiego Zjazdu Filozoficznego, Warszawa 1927; toż w: Tenże, Droga do filozofii, Państwowe Wydawnictwo Naukowe, Warszawa 1971, 109-115.

Thijssen-Schoute C.L., Nederlands Cartesianisme, Noord-Hollandsche Uitgevers Maatschappij, Amsterdam 1954.

Thomas Reid's lectures on natural theology, wyd. E. Duncan, University Press of America, Washington 1981.

Tuggy D., Reid's Philosophy of Religion, w: The Cambridge Companion to Thomas Reid, red. T. Cuneo, R. van Woudenberg, Cambridge University Press, Cambridge 2004, 289-312. 
Ventosa Águilar J.A., El Sentido común en las obras filosóficas del P. Claude Buffier, S. I. Contribución a la historia de la filosofía del sentido común, Seminario Conciliar de Barcelona, Barcelona 1957. Vuillemin J., Mathématique et métaphysique chez Descartes, Presses Universitaires de France, Paris 1960.

Wall G., Locke's Attack on Innate Knowledge, Philosophy 49(1974), 414-419; toż w: Locke on Human Understanding, red. I.C. Tipton, Oxford University Press, Oxford 1977, 1-18.

Wawrzonkowski K., O spostrzeżeniach zmystowych i ideach nabytych w filozofii Kartezjusza, „Roczniki Filozoficzne 63(2015)1, 49-64.

Weyer S., Die Cambridge Platonists. Religion und Freiheit in England im 17. Jahrhundert, Lang, Frankfurt am Main 1993.

Wilkins K.S., A Study of the Works of Claude Buffier, Institut et Musée Voltaire, Genève 1969.

Wilson D.B., Seeking Nature's Logic. Natural Philosophy in the Scottish Enlightenment, Pennsylvania State University Press, Pennsylvania 2009.

Winchester S.J., Locke and the Innatists, History of Philosophy Quarterly 2(1985), 411-420.

Wolff Ch., Kurtze Unterricht von der mathematischen Methode, w: Tenże, Anfangsgründe aller mathematischen Wissenschaften, Renger, Halle 1710; toż w: XVII i XVIII-wieczne popularne podręczniki studiowania matematyki. Ze szczególnym uwzględnieniem Christiana Wolffa „Krótkiego wykładu o matematycznej metodzie nauczania”, thum z niem. R. Kuliniak, T. Małysz, w: Oblicza filozofii XVII wieku, red. S. Janeczek, Wydawnictwo KUL, Lublin 2008, 335-356.

Wolff Ch., Mathematisches Lexicon, John Friedrich Gleditschens Seel Sohn, Leipzig 1716.

Wolff Ch., Philosophia rationalis sive logica, methodo scientifica pertractatum ad usum scientiarum atque vitae aptata, Renger, Francofurti 1740.

Wolterstorff N., Thomas Reid and the Story of Epistemology, Cambridge University Press, Cambridge 2001.

Woolhouse R.S., Locke's Philosophy of Science and Knowledge. A Consideration of Some Aspects of ,An Essay Concerning Human Understanding", Blackwell, Oxford 1971. 
Woozley A.D., Some Remarks on Locke's Account of Knowledge, Locke Newsletter 3(1972), 7-17.

Wójcik B.H., Reid as a pre-Kantian critical philosopher (from the continental point of view), Journal of Scottish Thought (2010), t. 3, Reid In His Time and Ours, 177-189.

Yolton J.W., A Locke Dictionary, Blackwell, Oxford 1993.

Yolton J.W., John Locke and the Way of Ideas, Oxford University Press, Oxford 1956.

Zabieglik S., Krzywe zwierciadło filozofii czyli dzieje pojęcia zdrowego rozsądku, Książka i Wiedza, Warszawa 1987.

Zabieglik S., Wiek doskonalenia. Z filozofii szkockiego Oświecenia, Zeszyty Naukowe Politechniki Gdańskiej, Filozofia III (1997)558. Ziegler R.H., Buchstabe und Geist. Pascal und die Grenzen der Philosophie, V \& R Unipress, Göttingen 2010.

Ziemiński I., Moralność i religia. Poglady filozoficzne Josepha Butlera, Wydaw. Naukowe PWN, Warszawa 2002, 196-207.

\title{
THE INTEGRAL CHARACTER OF HUMAN KNOWLEDGE ACCORDING TO BLAISE PASCAL: ON THE HISTORY OF THE PHILOSOPHY OF COMMON SENSE
}

\begin{abstract}
This paper discusses the conception of knowledge according to Blaise Pascal against the backdrop of epistemological discussions in the seventeenth and eighteenth centuries. It indicates the integral character of human knowledge as postulated by Pascal. This knowledge should combine reason, conceived in the sense of discourse, with intuition and instinct; on the other hand, it should combine natural knowledge and faith. Pascal goes beyond an array of truths accessible in the knowledge based on discourse (raison). He attributed a special role to intuition defined in terms of sentir or even instinct, using such categories as esprit de finesse, identified with sens droit or esprit de justesse, the categories essential in the knowledge of principes. At the same time this kind of endowment of the human mind (lumiere naturelle) corresponds in some respects to the knowledge grounded on cour, the knowledge set in opposition to raison, rationalistically understood, whereas in religion lumière naturelle is complementary to inspiration or révélation.

This approach, opposite to the naturalistic manifestations of rationalism, seems to belong to a long history of common sense philosophy that takes into account the realities of human nature. It goes back to Aristotle, despite the
\end{abstract}


modern contestation of his doctrine. The point of reference for Pascal is, above all, Descartes's epistemology. The French philosopher stressed the importance of the a priori elements of knowledge, the elements treated as a natural endowment of the human mind, to which intuition or instinct refer. As a result of the integral character of knowledge one approves of a philosophy that is conceived in a maximalist manner, even though this paradigm changed in modernity from metaphysical to epistemological. Now treating the then limitations with regard to metaphysics as a manifestation of minimalism, or even a peculiar agnosticism, does not seem to be justified. This is because of the fact that the modern paradigm had changed; it was epistemology that became the main territory on which basic philosophical debates were conducted. They brought about some definite solutions in worldview, solutions essential in view of the then domination of culture by religion. Perhaps it was the religious milieu that enforced metaphysical questions which would make up the foundation of religious worldview. In this context, the era's education implemented this requirement. At the end of the Enlightenment it preferred the Scottish school of common sense philosophy, the school that defended the integral character of human knowledge up against any manifestations of philosophical minimalism, or even peculiar skepticism, in itself dangerous for the cultural order.

Keywords: Blaise Pascal, René Descartes, Thomas Reid, history of epistemology, history of modern philosophy 